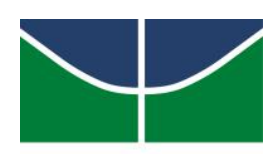

\title{
UnB
}

Universidade de Brasília

Instituto de Ciências Biológicas

Programa de Pós-Graduação em Ecologia

Demografia e autotomia caudal de dois lagartos endêmicos

de uma savana Neotropical

Heitor Campos de Sousa

Brasília - DF

2016 
Universidade de Brasília

Instituto de Ciências Biológicas

Programa de Pós-Graduação em Ecologia

\section{Demografia e autotomia caudal de dois lagartos endêmicos \\ de uma savana Neotropical}

Orientador: Dr. Guarino Rinaldi Colli

Dissertação apresentada ao Instituto de

Ciências Biológicas da Universidade de

Brasília como parte dos requisitos

necessários à obtenção do título de

Mestre em Ecologia

Brasília - DF

2016

Heitor Campos de Sousa 
Demografia e autotomia caudal de dois lagartos endêmicos de uma savana Neotropical

Dissertação realizada com o apoio da Coordenação de Aperfeç̧oamento de Pessoal de Nivel Superior (CAPES) e aprovada junto ao Programa de Pós-Graduação em Ecologia da Universidade de Brasilia como requisito para a obtenção do título de Mestre em Ecologia.

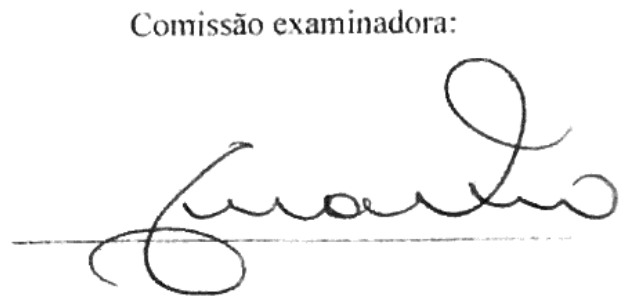

Prof. Dr. Guarino Rinaldi Colli

Presidente/Orientador

UnB

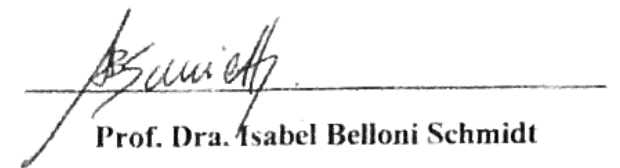

Membro interno vinculado ao Programa InB

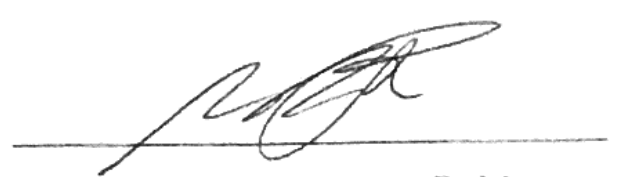

Prof. Dr. Murilo Guimarães Rodrigues Membro cxterno não vinculado ao Programa UFRGS

Prof. Dr. Emerson Monteiro Vieira

Membro interno vinculado ao Programa

UnB 


\section{AGRADECIMENTOS}

Agradeço ao apoio de toda a minha família, especialmente aos meus pais e à minha irmã;

Ao meu orientador Guarino, que se tornou um grande amigo. Agradeço pelos ensinamentos e lições que levarei para o resto da minha vida, tanto pessoal quanto acadêmica. Agradeço também ao Guarino pelas oportunidades e confiança que depositou em mim;

Agradeço a todos os companheiros da CHUNB!!! Todos se tornaram grandes amigos e colegas de trabalho e cada um me ajudou a crescer ou colaborou diretamente neste trabalho. Ísis, Lalá, Fabricius, Marcela Ayub, Jéssica dos Anjos, Jéssica Fenker e Léo, Tatá e Reuber, Ana Carolina, Verônica da Silva, Anandha, Gabi Rodrigues, João Pantoja, Helga Wiederhecker, Gabriel Caetano, Ana Hermínia, Almir, Guth Berger, Pietro, Pedro Baiano, André, Vitor Réi, Leandro de Nova Xavantina, Pedro da UFT e Tarcísio;

Um agradecimento especial ao Bernardo, Tânia e Davi Pantoja, que me acolheram muito bem no projeto FOGO, me ensinaram muito e se tornaram grandes amigos;

A todos os ajudantes de campo: Flora e Victor, Arthur Sena, Artur, Ana Cecília, Gabriel Caputo, Carol Azevedo, Bar, Matheus Nobre, Gabi Carvalho, Deborah Santos, Ellen Fernandes e ao Carlos José. Este último que se tornou um grande companheiro e que, tenho certeza, vai alcançar muito sucesso na vida profissional;

Aos professores e colegas do PPG em Ecologia, os quais me ensinaram muito;

À Garagem da UnB pela disponibilidade de motoristas e veículos para locomoção ao campo;

A todos os servidores da Reserva Ecológica do IBGE, que são muito prestativos e amigáveis e que chegaram a me ver no campo durante 5 anos. Desde aos porteiros até a diretoria e em especial à Miriam e à Betânia; 
Agradeço aos meus amigos da Biologia, que me apoiaram e acompanharam nesta jornada.

Em especial aos meus melhores amigos: Anna Carla, Mel, Hirata, Magal e Brisa;

À CAPES pela bolsa;

Finalmente, agradeço à minha namorada, Jullyana Brito Carmo, que me apoiou e me correspondeu nesses últimos meses de mestrado!!! 


\section{Índice}

Demografia e autotomia caudal de dois lagartos endêmicos de uma savana Neotropical......... 1

Capítulo 1: Regimes de queima e a demografia do lagarto Micrablepharus atticolus em um hotspot de biodiversidade

Capítulo 2: Correlações ecológicas de autotomia caudal em Micrablepharus atticolus em uma savana Neotropical.

Capítulo 3: Regimes de queima e a demografia de Tropidurus itambere (Tropiduridae, Squamata) em um hotspot de biodiversidade: viabilidade populacional sob diferentes históricos de queima

Capítulo 4: Autotomia caudal em um lagarto de uma savana Neotropical (Tropidurus itambere): padrões, custos e adaptabilidade

Conclusões Gerais 


\section{Demografia e autotomia caudal em dois lagartos endêmicos de uma savana Neotropical}

A ecologia de populações visa estudar como as interações bióticas e abióticas influenciam na dinâmica do tamanho populacional dos organismos. Os fatores bióticos, como competição e predação, são muitas vezes influenciados também pelas variações do ambiente. Fatores abióticos, como a precipitação e a temperatura afetam diferentemente as dinâmicas populacionais dos organismos e alguns destes podem ser negligenciados nos estudos, como as perturbações. Um tipo de perturbação proeminente em vários ecossistemas do mundo é o fogo. Já é difundido que o fogo tem papel importante na manutenção das paisagens e do funcionamento dos ecossistemas, assim como modificador de comunidades biológicas. Em animais, o efeito de queimadas podem ser divido em: diretos e indiretos. Os efeitos diretos são aqueles decorrentes da passagem imediata do fogo, gerando mortalidade. De outro lado, os efeitos indiretos são aqueles decorrentes após a passagem do fogo sobre a estrutura da vegetação, gerando um processo de sucessão após a queima. Em répteis, os efeitos diretos são quase inexistentes, sendo que os efeitos indiretos possuem uma importância preponderante sobre estes organismos. Apesar de muitos estudos do efeito do fogo sobre comunidades de animais, pouco se sabe sobre os efeitos indiretos sobre as populações de animais, já que as respostas são diversas e muitas vezes imprevisíveis. Além do mais, muitos estudos negligenciam os diferentes regimes de queima (queimadas em diferentes épocas do ano e/ou sob diferentes frequências) possíveis e presentes na região, e isso possivelmente pode acarretar a decisões equivocadas por parte do planejamento de manejo do fogo nos ecossistemas. Portanto, estudos com enfoque populacional, com métodos de marcação e recaptura e que consideram diferentes regimes de queima podem ser mais objetivos e trazer resultados mais diretos e menos enviesados para o manejo e conservação da biodiversidade. 
A autotomia caudal em lagartos é um mecanismo de defesa extremo, por gerar a perda de uma parte do corpo de um indivíduo para tentar se manter vivo, gerando custos. Os registros da frequência deste tipo de defesa foram historicamente usados como índices de intensidade de predação, já que se esperaria maior frequência de caudas autotomizadas em uma população. Porém, a frequência de caudas autotomizadas em populações naturais pode estar mais relacionada à ineficiência dos predadores ao tentarem capturar os indivíduos. Muito tempo se passou desde os primeiros estudos sobre o assunto e os efeitos da intensidade e da ineficiência da predação sobre a frequência de autotomia caudal em lagartos permanece elusiva. Portanto, estudos que consigam combinar dados demográficos com o registro de autotomia caudal em lagartos podem trazer resultados interessantes acerca da interação entre presa-predador. Além do mais, dados demográficos podem solucionar questões acerca dos custos da autotomia caudal em lagartos, já que é possível obter estimativas de sobrevivência, de crescimento e de condição corporal dos indivíduos.

Tendo isso em mente, o presente estudo teve como objetivos: 1. Estimar parâmetros demográficos e caracterizar a história de vida das espécies Micrablepharus atticolus e Tropidurus itambere; 2. Avaliar as respostas das populações das mesmas duas espécies sob diferentes regimes de queima, pela estrutura etária, pelas taxas de captura (detectabilidade), sobrevivência e recrutamento; 3. Investigar fatores que influenciam a probabilidade dos indivíduos das duas espécies terem a cauda partida; 4. Investigar os custos da autotomia pela condição corporal, sobrevivência, crescimento e taxa de regeneração. Ambas as espécies são endêmicas do Cerrado, possuem ampla distribuição, são heliófilas e mais abundantes em hábitats abertos. Micrablepharus atticolus costuma se enterrar na serapilheira e na terra, enquanto que Tropidurus itambere, em 
algumas regiões, empoleira em afloramentos rochosos e em galhos. Machos de T. itambere são territorialistas e pequenas áreas de vida.

Os resultados deste trabalho mostram que em ambientes tropicais e sazonais, apesar de negligenciados, a insolação e temperaturas extremas podem influenciar populações de animais, principalmente aqueles ectotérmicos. Estas variáveis climáticas, em conjunto com o efeito da precipitação, provavelmente influenciam a reprodução sazonal das duas espécies, por influenciar a abundância de presas para os jovens e as condições ótimas para a oviposição e desenvolvimento dos ovos. Ambas as espécies possuem curto ciclo de vida, com a maioria dos indivíduos vivendo por apenas um ano de vida, afetando desta forma diretamente a variação da estrutura etária ao longo do ano.

Ambas as espécies são mais abundantes em ambientes mais abertos no Cerrado, por isso esperava-se que as espécies fossem beneficiadas por regimes de queima mais severos (maior mortalidade de lenhosas, portanto maior abertura do hábitat). Porém, em ambas as espécies, as populações nos regimes de queima mais severo apresentaram alta mortalidade e/ou baixo recrutamento. Este resultado provavelmente é devido à facilidade de visualização por parte dos predadores e pela baixa umidade decorrente da alteração do microclima causada pelo regime de queima mais severo.

No regime de queima menos severo (supressão do fogo), encontrou-se menor recrutamento e menos capturas em ambas as espécies. Em Tropidurus itambere, também verificou-se que indivíduos jovens possuem menor sobrevivência quando comparados com outros regimes de queima. A supressão do fogo leva ao adensamento da vegetação, o que gera microclima e hábitat desfavorável a ambas espécies, já que elas são heliófilas. Tendo em vista isso, era esperado que as populações das espécies possuíssem parâmetros desfavoráveis para a permanência das populações. 
Os resultados acerca da frequência de autotomia caudal revelaram que a intensidade de predação em lagartos do Cerrado pode ser mais importante em comparação com a ineficiência de predação. Isto porque as frequências de autotomia caudal de Micrablepharus atticolus foram baixas quando comparadas ao acaso no regime de queima de severidade intermediária, onde houve menor sobrevivência. Além do mais, nos extremos do gradiente de abertura do habitat coincide a alta taxa de mortalidade das populações com a abundância de predadores, como aranhas e aves.

Os custos da autotomia caudal nas duas espécies estudadas são insignificantes quanto ao crescimento e à condição corporal. Porém, em T. itambere, observou-se que machos autotomizados tendem a ter menor sobrevivência com machos intactos, enquanto que o contrário acontece para indivíduos jovens e fêmeas. Este resultado é provavelmente efeito do comportamento territorialista dos machos, o que os expõe mais a predadores, quando compara-se com fêmeas e jovens. Indivíduos fêmeas e jovens foram menos capturados, evidenciando um decréscimo no período de atividade dos indivíduos ou uma mudança de comportamento de forrageio ou de defesa, os quais os machos não podem contar. Portanto, espécies territorialistas e com dimorfismo sexual, como Tropidurus itambere, podem sofrer de maiores custos decorrentes da autotomia caudal, podendo gerar consequências para a dinâmica das populações.

Este trabalho sugere a necessidade da criação de um programa de manejo de fogo no Cerrado, e que queimadas prescritas no começo ou no meio da estação seca (junho a agosto) beneficiam as populações de Micrablepharus atticolus e de Tropidurus itambere. Por outro lado, a supressão total do fogo ou queimadas frequentes e intensas prescritas no final da estação seca prejudicam as espécies. Além do mais, tais regimes podem aumentar a probabilidade de predação, ou por deixarem os indivíduos mais expostos, ou por aumentar a abundância de predadores de lagartos, em geral. 


\section{Capítulo 1: Regimes de queima e a demografia do lagarto Micrablepharus atticolus em um hotspot de biodiversidade}

Distúrbios causados por queimadas antrópicas estão afetando intensamente a biodiversidade de ecossistemas suscetíveis ao fogo em todo o mundo. O Cerrado, um hotspot de biodiversidade, sofre taxas de desmatamento mais altas que a Amazônia e concentra a maior parte das áreas queimadas na América do Sul. Para auxiliar decisões adequadas para o manejo de fogo no Cerrado, é necessário o conhecimento sobre as mudanças nos efeitos de regimes de queima sobre populações animais. Baseados em um experimento de longo prazo e de larga escala, nós investigamos os efeitos de diferentes regimes de queima sobre a demografia do gimnoftalmídeo Micrablepharus atticolus, um lagarto endêmico do Cerrado. Já que M. atticolus é mais abundante em habitats abertos, nós predissemos que queimadas frequentes devem favorecer suas populações. Durante oito anos, nós conduzimos um estudo de marcação e recaptura usando armadilhas de interceptação e queda em quatro parcelas de 10 ha de cerrado sensu stricto, sujeitas a queimadas prescritas e uma parcela controle. Usando modelos lineares generalizados mistos de dados de uma série temporal e de uma abordagem da teoria da informação para selecionar modelos demográficos, nós descrevemos a história de vida de $M$. atticolus e avaliamos a resposta da sobrevivência aparente, da detectabilidade e do recrutamento aos regimes de queima e à variação climática. Micrablepharus atticolus tem um ciclo de vida anual, com substituição anual completa da população; a reprodução ocorre durante a estação seca, quando a atividade é mais alta e os recém-nascidos aparecem na estação chuvosa. A sobrevivência aparente, detectabilidade e recrutamento aumentaram em curto prazo depois da passagem do fogo em todas as parcelas experimentais. Em longo prazo, porém, tanto a supressão do fogo e regimes de queima mais 
severos pareceram prejudiciais, provavelmente por afetarem as condições microclimáticas e a disponibilidade alimentar. Nossos resultados mostram que estudos de curto prazo podem não descrever adequadamente os efeitos do fogo sobre a demografia de populações de lagartos. Um programa de manejo adequado do fogo é necessário para a conservação da biodiversidade no Cerrado, tanto dentro e fora de áreas protegidas, incluindo uma redução da frequência e da intensidade de queimadas em fisionomias abertas e queimadas controladas em mosaicos de fragmentos de vegetação para prevenir acumulação excessiva de combustível em fisionomias mais densas. 


\title{
Fire Regimes and the Demography of the Lizard Micrablepharus atticolus (Squamata, Gymnophthalmidae) in a Biodiversity Hotspot
}

\author{
Heitor C. de Sousa ${ }^{1}$, Ana Hermínia S.B. Soares ${ }^{1}$ Bernardo M. Costa ${ }^{2}$, Davi L. Pantoja ${ }^{3}$, \\ Gabriel H. Caetano ${ }^{4}$, Tânia A. de Queiroz ${ }^{1}$, Guarino R. Colli' ${ }^{1 *}$
}

\footnotetext{
${ }^{1}$ Departamento de Zoologia, Universidade de Brasília, Campus Universitário Darcy Ribeiro, Asa Norte, CEP 70910-900, Brasília, DF, Brazil. 2 Instituto Federal de Brasília, Campus Gama, Lote 01, DF 480, Setor de Múltiplas Atividades, CEP 72429-005, Gama, DF, Brazil.

${ }^{3}$ Campus Professora Cinobelina Elvas, Universidade Federal do Piauí, Rodovia Municipal Bom Jesus-Viana, km 01, CEP 64900-000, Bom Jesus, PI, Brazil.

4 University of California, Santa Cruz, Department of Ecology \& Evolutionary Biology, Earth \& Marine Sciences Building, Santa Cruz, CA, 95064, USA.

* Corresponding author. E-mail: grcolli@unb.br
}

\begin{abstract}
Disturbance caused by anthropogenic fires are increasingly affecting the biodiversity of fire-prone ecosystems worldwide. The Cerrado biodiversity hotspot suffers higher deforestation rates than Amazonia and concentrates most of the burned areas in South America. To support adequate fire-management decisions in Cerrado, knowledge on the effects of altered fire regimes upon its animal populations is necessary. Based on a long-term, large-scale fire experiment, we investigated the effects of different fire regimes on the demography of the gymnophthalmid Micrablepharus atticolus, an endemic lizard of the Cerrado. Because M. atticolus is more abundant in open habitats, we predicted that frequent burns should favor its populations. Over eight years, we conducted a mark-recapture study using pitfall trap arrays in five 10 ha plots of cerrado sensu stricto, subjected to prescribed burns. Using generalized linear mixed-models of time series data and an information theoretic approach to select demographic models, we describe the life history of $M$. atticolus and assess the response of apparent survival, detectability, and recruitment to burn regimes and climate variation. Micrablepharus atticolus has an annual life cycle, with complete annual population turnover; breeding takes place during the dry season, when activity is higher, and hatchlings appear in the wet season. Apparent survival, detectability, and recruitment increased in the short-run after the passage of fire in all experimental plots. In the long run, however, both fire-suppression and more severe fire regimes were seemingly detrimental, presumably by affecting microclimatic conditions and food availability. Short-term studies may not adequately describe the effects of fire on the demography of lizard populations. Adequate fire management is warranted for biodiversity conservation in Cerrado, both inside and outside protected areas, including a reduction in the frequency and severity of burns in open physiognomies and controlled, patch mosaic fires to prevent excessive fuel accumulation in denser physiognomies.
\end{abstract}

Keywords. Cerrado; Conservation; Detectability; Life history; Mark-recapture; Population dynamics; Recruitment; Survival.

\section{INTRODUCTION}

Fire is a major driver of environmental change that has shaped the ecology and evolution of most terrestrial ecosystems (Booysen and Tainton, 1984; Goldammer, 1990; Veblen et al., 2003; Cochrane, 2009). It is a key feature of flammable ecosystems, such as boreal forests (Goldammer and Furyaev, 1996; Kasischke and Stocks, 2000) and Mediterranean shrublands (van Van Wilgen et al., 1992; Moreno and Oechel, 1994; Chuvieco, 2009), and the fire-adapted savannas and grasslands (Andersen et al., 2003; Bond and Keeley, 2005; Bond et al., 2005). Since early humans mastered fire, anthropogenic practices have promoted an unprecedented increase in the intensity and frequency of wildfires and, more recently, also fire suppression and management (Bowman et al., 2009; Conedera et al., 2009; Pausas and Keeley, 2009; Bowman et al., 2011; Roebroeks and Villa, 2011). The disturbance of natural fire regimes can profoundly affect animal populations, by influencing resource availability (Radford and Andersen, 2012; Moranz et al., 2014; O’kane et al., 2014), predation rates (Attum and Eason, 2006; Karpestam et al., 2012; Eby and Ritchie, 2013), reproductive success (Kochert et al., 1999; Little et al., 2013; Rota et al., 2014), thermoregulation (Webb et al., 2005; Kortello and Ham, 2010; Hossack et al., 2013), and even social interactions (Banks et al., 2012). Therefore, a thorough understanding about the effects of wildfires upon animal populations is crucial for environmentally sound and sustainable fire management practices (Secretariat of the Convention on Biological Diversity, 2001).

Because most reptiles are ectothermic and smallbodied (Vitt and Caldwell, 2009), they should be especially susceptible to wildfires; however, some species have striking adaptations to cope with the passage of fire (Russell et al., 1999; Costa et al., 2013). Reptile populations and communities show varied responses to wildfires (Griffiths and Christian, 1996; Faria et al., 2004; Fenner and Bull, 2007). Fires may increase the mortality of terrestrial turtles (Hailey, 2000; Popgeorgiev, 2008; Sanz-Aguilar et al., 2011) and snakes (Webb and Shine, 2008; Lyet et al., 2009), but may favor lizard population 
growth, recruitment and body condition (Mushinsky, 1985). Fires are known to promote increased diversity of lizard communities in a variety of ecosystems, including sandhills (Mushinsky, 1985), forests (Moseley et al., 2003; Bury, 2004; Greenberg and Waldrop, 2008), pine woodlands (Greenberg et al., 1994; Ford et al., 1999; Perry et al., 2009), pine savannas (Langford et al., 2007), prairies (Cavitt, 2000; Wilgers and Horne, 2007), chaparral (Cunningham et al., 2002; Ruthven et al., 2008), Eucalyptus open forests (Singh et al., 2002; Woinarski et al., 2004), deserts (Pianka, 1996; Letnic et al., 2004; Pianka and Goodyear, 2012), Spinifex grasslands (Masters, 1996) and tropical savannas (Andersen et al., 2005; Nicholson et al., 2006; Valentine and Schwarzkopf, 2009). Still, fires can also lead to a reduction of species diversity and abundance in lizard communities (Legge et al., 2008; Cano and Leynaud, 2009; Pelegrin and Bucher, 2010). Fire suppression can limit the flow of individuals within and among populations (Brisson et al., 2003; Templeton et al., 2011), but may favor the abundance of species that use the leaf litter (Mushinsky, 1992).

Given the varied responses of herpetofauna to fire, studies of individual species may be necessary to make adequate fire-management decisions (Driscoll and Henderson, 2008; Lindenmayer et al., 2008; Driscoll et al., 2010). Detailed demographic studies may reveal species needs and tolerances on habitat resources, microclimatic factors, predation rates, and burn regimes, predicting responses to fire and thus avoiding local extinctions (Clarke, 2008; Templeton et al., 2011). Nevertheless, few studies have accounted for detectability when assessing the effects of fires upon animal populations, especially because of the substantial costs involved in obtaining such data (Driscoll et al., 2010; Smith et al., 2012). Ignoring changes in detection probability due to individual, spatial, and temporal variation may severely bias demographic estimates (Anderson, 2001; Bailey et al., 2004; Guimarães et al., 2014).

The Cerrado is the largest Neotropical savanna (Eiten, 1972; Oliveira and Marquis, 2002; Diniz et al., 2010) and also a biodiversity hotspot, due to its amazing biodiversity and high levels of habitat destruction (Mittermeier et al., 1998; Myers et al., 2000). Fire plays a prominent role in the dynamics of Cerrado ecosystems (Mistry, 1998; Hoffmann and Moreira, 2002; Miranda et al., 2002, 2009). Natural fires are initiated by lightning during the rainy period, but do not reach uncontrollable levels due to frequent rainfall (Ramos-Neto and Pivello, 2000). Traditionally, rural and indigenous populations have used fire as a vegetation management tool, but the frequency and intensity of fires has increased in recent years due to the growth of the agribusiness and urban populations (Klink and Machado, 2005; Mistry and Bizerril, 2011; Pivello, 2011). Therefore, the natural fire regime in Cerrado has been modified by human activities, leading to more frequent and severe fires late in the dry season, when the environment contains more fuel and less moisture (Mistry, 1998; Miranda et al., 2002). Brazil concentrates most of the total fires that occur in South America (63\% of all fire pixels, Di Bella et al., 2006) and the Cerrado presents the largest concentration of fires in Brazil (73\%, Araújo et al., 2012). As fire has occurred naturally for millennia in Cerrado (Miranda et al., 2009; Simon et al., 2009), it is expected that its fauna is fire-adapted, but very little is known about the effects of altered fire regimes upon animal populations in Cerrado (Redford and Fonseca, 1986; Coutinho, 1990).

The effects of fire on the Cerrado herpetofauna are still poorly understood, although extremely important for the adequate management of natural landscapes (Frizzo et al., 2011). In central Brazil, fires of intermediate frequency and severity promote an increase in the diversity of lizard communities (Pantoja, 2007), direct effects of fire on lizards seem negligible and, in the short term, the abundance of most lizard species increases (Costa et al., 2013). Herein, based on a long-term and large-scale prescribed fire experiment, we describe the life history of the Cerrado endemic lizard, Micrablepharus atticolus Rodrigues, 1996, and assess the response of apparent survival, detectability, and recruitment to burn regimes and climate variation. This species is broadly distributed in Cerrado, also occupying peripheral isolates within Amazonia (Vitt and Caldwell, 1993; Gainsbury and Colli, 2003; Santos et al., 2014). Micrablepharus atticolus is heliophilous, being active during the hottest hours of the day, feeds on several groups of arthropods and lays multiple clutches in the breeding season (Vitt, 1991; Vitt and Caldwell, 1993; Vieira et al., 2000). It is restricted to open, often sandy habitats, and has the habit of foraging and burying itself in the litter, grass and soil (Vitt, 1991; Colli et al., 2002; Gainsbury and Colli, 2003; Nogueira, 2006). Because M. atticolus is more abundant in open Cerrado physiognomies (Vitt, 1991; Rodrigues, 1996; Vieira et al., 2000), including habitats with severe burn regimes (Pantoja, 2007; Costa et al., 2013), we hypothesize that fires positively affect its populations through enhanced apparent survival and recruitment, and that fire suppression has the opposite effects.

\section{MATERIALS AND METHODS}

\section{Study area}

We conducted this study in Reserva Ecológica do Roncador (RECOR; 1556'41”S, 4753’07”W), Brasília, Distrito Federal, Brazil, in the core of the Cerrado biome (Eiten, 1972). Climate is markedly seasonal, with a wet season from October to April, followed by a dry season from May to September (Nimer, 1989). From 1972-1990, the RECOR was fully protected from fires. In 1989, however, 
a long-term experiment was initiated to evaluate the effects of different burn regimes on animals and plants (Miranda, 2010; Pivello et al., 2010; Miranda et al., 2011). A uniform sampling area was divided into 10 ha plots, each submitted to a different regime characterized by a combination of the timing (early dry season: in late June, middle dry season: in early August, and late dry season: in late September) and frequency (biennial and quadrennial) of burns. In addition, there were control, unburned plots. Because plots were placed in the same physiognomy and shared the same history of burns prior to the onset of the experiment, we assumed that differences between plots through time arose from the effects of prescribed burn regimes. We selected five plots (Fig. 1) in the cerrado sensu stricto physiognomy (Ribeiro and Walter, 1998): three subjected to prescribed biennial burns (early biennial, EB; middle biennial, MB; and late biennial, LB), one subjected to prescribed quadrennial burns (middle quadrennial, Q), and one control plot (C). Fire severity increased along the sequence $\mathrm{C} \rightarrow \mathrm{Q} \rightarrow \mathrm{EB} \rightarrow \mathrm{MB} \rightarrow \mathrm{LB}$. The last prescribed burns occurred in 2007 in quadrennial plots (five burns in each plot) and 2008 in biennial plots (nine burns in each plot). In September 2011, an unplanned fire partially burned the $\mathrm{LB}$, and completely burned the $C$ plot. With the exception of the $C$ plot, all other plots were adjacent to each other, separated by a ca. $5 \mathrm{~m}$-wide dirt road (Fig. 1). In addition to the costs and difficulties of replication typical of large-scale ecologic studies (Carpenter, 1990; Oksanen, 2001), our experiment could not be replicated because of legal issues associated with burning the vegetation inside protected areas. We recognize that this reduces the statistical power of our study, but such large-scale manipulative experiments are the only way to ensure the availability of adequate treatment levels (Driscoll et al., 2010). Therefore, we restrict our statistical inferences to the study areas, considering our sampling methodology as adequate to represent them.

\section{Captures and recaptures}

From November 2005 to March 2013, we monitored the populations of Micrablepharus atticolus in study plots, capturing animals with the aid of pitfall traps. Each trap consisted of four $30 \mathrm{~L}$ buckets buried in the ground in a "Y" shape, interconnected by $6 \mathrm{~m}$-long metal drift fences. At the center of each plot, we placed ten traps along a linear transect. Traps were opened for six consecutive days every month and checked daily. Considering the distance between transects in adjacent plots (ca. $200 \mathrm{~m}$ ), the very
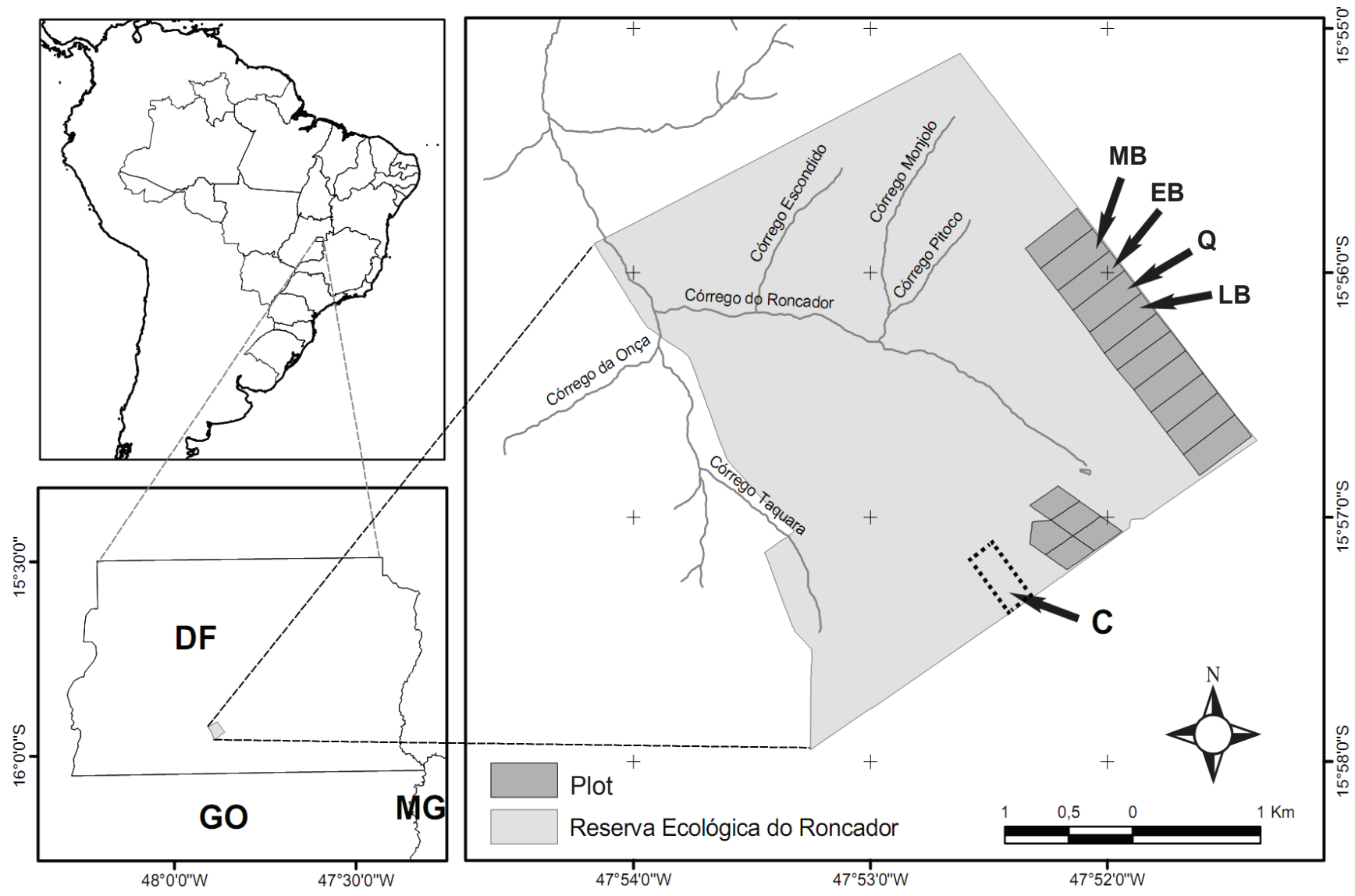

Figure 1. Map with location of the studied plots: late biennial (LB), middle biennial (MB), early biennial (EB), and quadrennial (Q) burns and the control without fire until 2011 (C). 
small size of the study species (see Results), and the dirt road separating adjacent plots, we did not expect lizard movements between adjacent plots to affect our results. Indeed, during the entire period of this study there was not a single recapture indicative of movements between plots. We recorded the snout-vent length (SVL) with a ruler (1 $\mathrm{mm}$ precision) and sex of each captured lizard, followed by individual marking (toe clipping) and release at the capture site. We determined sex by hemipenis eversion in males and visual detection of eggs in females. To assess differences in the number of captures or recaptures among plots, we used sequential $\chi^{2}$ tests, removing variables (plots) from analyses based on their $\chi^{2}$ residuals until differences among plots were no longer significant (Zar, 2010).

\section{Variation in age structure}

To identify seasonal or cyclic patterns and trends in the age structure of the lizard population in each plot, we transformed monthly means of SVL into time series. As we captured no lizards in some months/plots, and the time-series analyses cannot have missing data, we used multiple imputation (Rubin, 1996; Zhang, 2003) to replace missing data and estimate statistical parameters, with package Amelia II (Honaker et al., 2011) in R (R Core Team, 2014). Amelia II uses an expectationmaximization (EM) algorithm (Dempster et al., 1977) in combination with bootstrap sampling to replace missing values in the original data set. We ran 1,000 multiple imputations of missing monthly means of SVL, using sample (1-89 monthly samples from November 2005 to March 2013) as the time series variable, month (1-12, e.g. January to December) as the cross-section variable, and included several climatic variables to improve prediction (Honaker et al., 2011). We obtained monthly means of climatic variables from the RECOR meteorological station: wind speed (wind), precipitation (precip), evaporation (evap), relative air humidity (humid), insolation (sun), average air temperature (tmed), maximum air temperature $(t \max )$ and minimum air temperature (tmin).

We built a correlogram to identify cyclic patterns in SVL variation and created cyclic sine and cosine wave patterns along the months and among the years to test for the existence of a trend. To assess the influence of climatic variables on monthly means of SVL, we used an information-theory approach (Burnham and Anderson, 2002; 2004), based on the Akaike information criterion corrected for finite sample sizes (AIC), to select linear mixedeffects (LME) models relating monthly means of SVL to climatic variables, with packages Ime4 (Bates et al., 2014) and MuMIn (Bartón, 2014) of R (R Core Team, 2014). We undertook an exhaustive screening of all possible models to assess predictor importance, determined as the sum of the Akaike weights for all models containing a given predictor, and retained those where $\Delta \mathrm{AIC}_{c} \leq 2$ to assess predictor coefficients (Burnham and Anderson, 2002). To account for the temporal pseudoreplication resulting from plots being sampled several times over the course of the study, we used the sine and cosine wave patterns previously identified and year as random factors in the LME models (Crawley, 2013; Galecki and Burzykowski, 2013).

We used LME models to assess differences in SVL among plots along the year. In this analysis, we used fire regime (plot) and month (1-12) as fixed factors and year (2005-2013) as a random factor. We assessed the significance of the fixed factors and their interaction by comparing the full model with simpler models, sequentially dropping terms and using a significance test $\left(\chi^{2}\right)$ of the reduction in scaled deviance (Crawley, 2013). We conducted all analyses in R (R Core Team, 2014) and used a significance level of $5 \%$ in hypothesis testing.

\section{Demographic analyses}

We used individual capture histories of Micrablepharus atticolus from November 2005 to March 2013 to assess the effects of climate variables and fire regimes on estimates of demographic parameters. We used Pradel models, which estimate the probabilities of survival $(\Phi)$, capture $(p)$ and recruitment $(f)$. We implemented the analyses in two steps, using RMark 2.1 (Laake, 2013) and MARK 6.2 (White and Burnham, 1999). In the first step, we used model selection and model averaging to identify climate variables that best explain capture histories. We started the analysis with a general model, where $\Phi$, $p$, and $f$ were constrained by all climatic variables. To ensure that this general model adequately fitted the data, we conducted a goodness-of-fit (GOF) test, by comparing our general model with a saturated model where survival and recapture probabilities were constrained by the interaction of fire regime and capture occasion $\left(\Phi\left(g^{*} t\right)\right.$, $p\left(g^{*} t\right)$ ), with U-CARE 2.3.2 (Choquet et al., 2009). Next, we conducted a heuristic stepwise model selection based on AICc, retaining those models with $\triangle \mathrm{AIC} c \leq 2$ (Burnham and Anderson, 2002; 2004). Finally, we assessed parameter importance as indicated above.

In the second step, we used model selection and model averaging to identify fire-related variables that best explain capture histories. Thus, we constrained $\Phi$, $p$, and $f$ by the climate variables identified in the first step and by burn frequency (biennial, quadrennial, and control), timing (late, middle, early and control), regime (LB, MB, EB, Q, and C) and a binomial vector indicating the occurrence of fire in each plot (0: no fire, 1: fire). In this way, we attempted to model both the long-term (frequency, time, regime) and short-term (occurrence) effects of fire, accounting for variation in climate. We conducted 
model selection and averaging as indicated above, in the first step.

\section{RESULTS}

From November 2005 to March 2013 we marked 465 individuals of Micrablepharus atticolus, representing 729 captures and recaptures in the five monitored plots (Fig. 2). On average, each lizard was recaptured on 0.64 occasions during the study. We made significantly more captures and recaptures in the middle biennial and less in the control plot (Fig. 2, sequential $\chi^{2}$ tests, $P<0.001$ ).

The temporal variation in the SVL of captured lizards revealed a markedly seasonal pattern, with little overlap of generations (Fig. 3). An autocorrelation analysis of monthly means of SVL based on 1,000 imputed datasets indicated that temporal autocorrelation is highest for a gap of 12 months (mean $a c f=0.51$ ), i.e., there is a clear annual cycle of population SVL. Hatchlings appear in the population as early as September, at the end of the dry season, and individuals attain sexual maturity at $35 \mathrm{~mm}$ SVL (based on the smallest female bearing eggs) as early as February of the following year. Reproduction takes place during the dry season: we recorded 16 females bearing eggs, from May to September (May: 1, June: 2, July: 3, August: 7, and September: 3). Overall, the low mean recapture rate, little overlap of generations, and cyclic variation in SVL indicate an annual life cycle, with breeding taking place in the dry season and juveniles hatching at the onset of the rainy season (Fig. 4).

The model selection analysis of LME models relating monthly means of SVL to climatic variables retained 12 models in which $\triangle \mathrm{AIC}_{\mathrm{c}} \leq 2$. Insolation was by far the best predictor of Micrablepharus atticolus SVL (Table 1), with larger mean SVLs recorded in months with higher insolation (i.e., during the dry season).

There were no effects of the interaction of fire regime with month (i.e., no significant effect of dropping the interaction term on the scaled deviance; $\chi_{[4]}^{2}=4.57$, $P=0.34$ ) or of fire regime (i.e., no significant effect of dropping the interaction term and fire regime upon the scaled deviance; $\chi_{[4]}^{2}=7.88, P=0.10$ ) on SVL (Fig. 5). Month was the only significant fixed effect on SVL variation (i.e.,

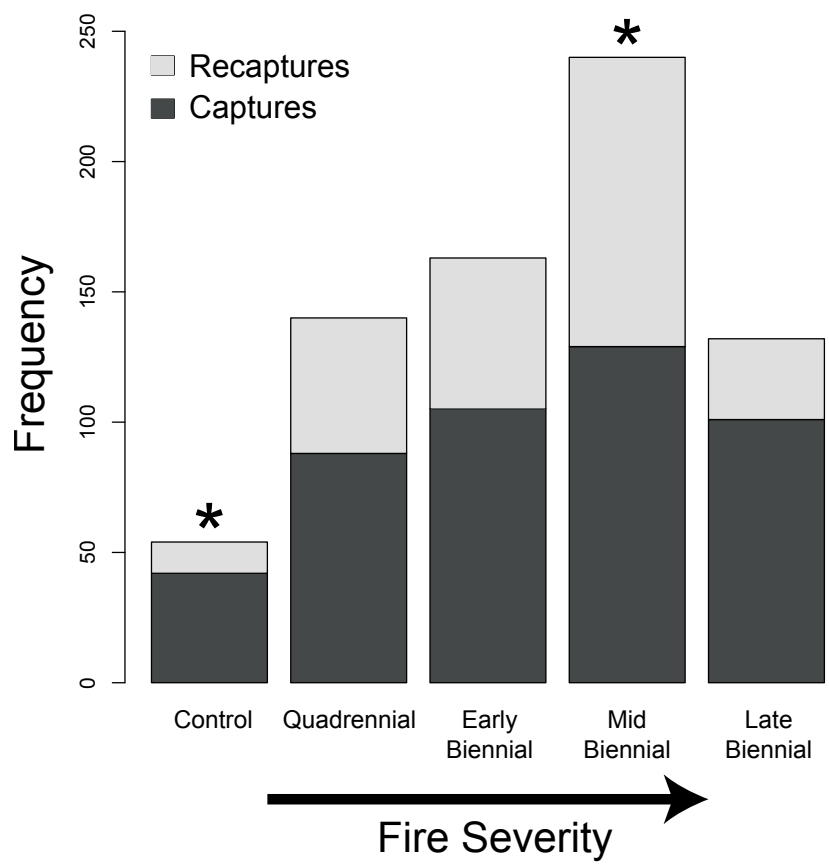

Figure 2. Captures and recaptures of Micrablepharus atticolus in cerrado sensu stricto control and treatment plots of varying fire severity, in central Brazil. Asterisks indicate plots where captures and recaptures differed from the remainder.

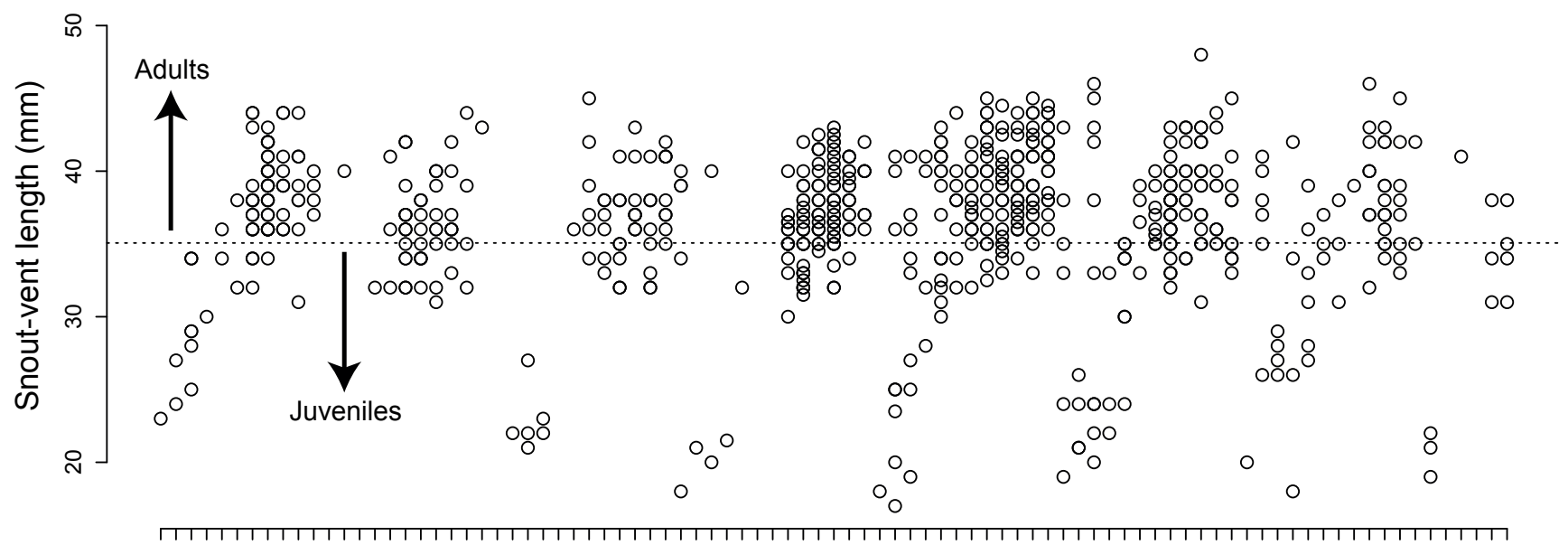

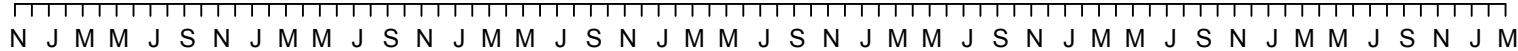

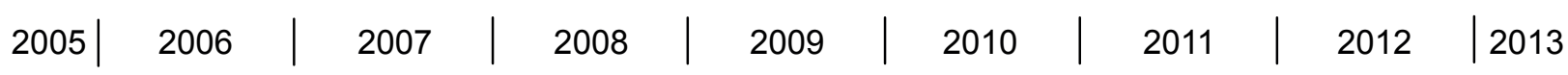

Figure 3. Snout-vent length (SVL) of Micrablepharus atticolus captured from 2005-2013, in cerrado sensu stricto control and treatment plots of varying fire severity, in central Brazil. Dashed line indicates SVL at sexual maturity (35 mm). 
Table 1. Coefficients, Akaike information criterion adjusted for small samples (AIC), and relative variable importance of 12 linear mixed-effects models, where $\triangle \mathrm{AIC}_{c} \leq 2$, relating monthly means of the SVL of Micrablepharus atticolus to climate predictors, in Reserva Ecológica do Roncador - RECOR, Brasília, Distrito Federal, Brazil, from November 2005 to March 2013. Wind speed (wind), precipitation (precip), evaporation (evap), relative air humidity (humid), insolation (sun), average air temperature (tmed), maximum air temperature (tmax) and minimum air temperature (tmin).

\begin{tabular}{|c|c|c|c|c|c|c|c|c|c|c|}
\hline Model & Intercept & insol & humid & $t \max$ & tmed & evap & tmin & wind & precip & $\mathbf{A I C}_{c}$ \\
\hline 1 & 23.97 & 2.26 & 0.15 & - & -0.73 & - & - & - & - & 482.59 \\
\hline 2 & 27.52 & 2.30 & 0.13 & -0.68 & - & - & - & - & - & 482.65 \\
\hline 3 & 50.23 & 1.74 & - & -1.03 & - & - & - & - & - & 483.02 \\
\hline 4 & 2.09 & 2.57 & 0.20 & - & - & - & - & - & - & 483.11 \\
\hline 5 & 11.19 & 2.16 & 0.20 & - & - & - & -0.44 & - & - & 483.19 \\
\hline 6 & 41.69 & 2.04 & - & -0.71 & - & -0.43 & - & - & - & 483.83 \\
\hline 7 & 38.87 & 1.98 & - & - & -0.71 & -0.52 & - & - & - & 484.10 \\
\hline 8 & 22.40 & 2.25 & - & - & - & -0.77 & - & - & - & 484.21 \\
\hline 9 & 47.26 & 1.54 & - & - & -1.08 & - & - & - & - & 484.31 \\
\hline 10 & 5.15 & 2.17 & 0.22 & - & - & - & - & - & -0.30 & 484.42 \\
\hline 11 & 21.11 & 2.32 & 0.17 & - & -0.72 & - & - & 0.78 & - & 484.46 \\
\hline 12 & 24.54 & 2.37 & 0.15 & -0.66 & - & - & - & 0.75 & - & 484.56 \\
\hline Importance & & 1.00 & 0.59 & 0.43 & 0.38 & 0.36 & 0.31 & 0.28 & 0.27 & \\
\hline
\end{tabular}

Table 2. Best Pradel models estimating the probabilities of survival $(\Phi)$, recapture $(p)$ and recruitment ( $f$ ) of Micrablepharus atticolus in Brasília, Distrito Federal, Brazil, from November 2005 to March 2013, constrained by climate variables. Precip: precipitation; humid: relative air humidity; sun: insolation; tmax: maximum air temperature; tmed: average air temperature; tmin: minimum air temperature; AICc: Akaike information criterion corrected for small sample size; wAICc: Akaike weight.

\begin{tabular}{|c|c|c|c|c|}
\hline Model & AICc & $\Delta \mathbf{A I C c}$ & Deviance & WAICc \\
\hline$\Phi(\sim$ sun+humid $) p(\sim$ precip+tmin+sun $) f(\sim$ tmed + sun + humid+tmin $)$ & 5590.05 & 0.00 & 1225.27 & 0.18 \\
\hline$\Phi(\sim$ sun+humid $) p(\sim$ precip+tmin+sun+humid $) f(\sim$ tmed + sun + humid + tmin $)$ & 5591.04 & 0.99 & 1224.18 & 0.11 \\
\hline$\Phi(\sim$ sun+humid $) p(\sim$ precip+tmin $)$ f( tmed+sun+humid+tmin $)$ & 5591.06 & 1.01 & 1228.35 & 0.11 \\
\hline$\Phi(\sim$ sun+humid $) p(\sim p r e c i p+t m i n+s u n+t m a x) f(\sim$ tmed + sun + humid+tmin $)$ & 5591.07 & 1.02 & 1224.21 & 0.11 \\
\hline$\Phi(\sim$ sun + humid + precip $) p(\sim$ precip+tmin + sun + tmax $) f(\sim$ tmed + sun + humid + tmin $)$ & 5591.44 & 1.39 & 1222.49 & 0.09 \\
\hline$\Phi(\sim$ sun+humid+precip) $p(\sim$ precip+tmin+sun $) f(\sim$ tmed+sun+humid+tmin $)$ & 5591.46 & 1.41 & 1224.59 & 0.09 \\
\hline$\Phi(\sim$ sun+humid+tmin $) p(\sim p r e c i p+t m i n+s u n) f(\sim$ tmed+sun+humid+tmin $)$ & 5591.54 & 1.49 & 1224.68 & 0.09 \\
\hline$\Phi(\sim$ sun+humid $) p(\sim$ precip+tmin+sun $) f(\sim$ tmed + sun+humid+tmin+tmax $)$ & 5591.58 & 1.54 & 1224.72 & 0.08 \\
\hline$\Phi(\sim$ sun + humid $) p(\sim$ precip+tmin + sun $) f(\sim$ tmed + sun + humid + tmin + precip $)$ & 5591.87 & 1.83 & 1225.01 & 0.07 \\
\hline$\Phi(\sim$ sun+humid $) p(\sim$ precip+tmin+sun+tmed $) f(\sim$ tmed + sun + humid + tmin $)$ & 5591.91 & 1.87 & 1225.05 & 0.07 \\
\hline
\end{tabular}

significant increase in scaled deviance after dropping all fixed effects and their interaction; $\chi^{2}{ }_{[1]}=7.22, P=0.007$ ).

The model selection analysis with the probability of survival $(\Phi)$, capture $(p)$, and recruitment $(f)$ constrained by climate variables retained 10 models with $\Delta \mathrm{AICc} \leq 2$ (Table 2). A model averaging analysis (not shown) of the 10 models indicated that the most important climate parameters (importance $>0.9$ ) were exactly those in the best model $[\Phi(\sim$ sun+humid $) p(\sim$ precip+tmin+sun $)$ $f(\sim$ tmed+sun+humid+tmin)] and that insolation was the only covariate important for the estimation of all three demographic parameters. In the model selection with $\Phi$, $p$, and $f$ constrained by the climate variables identified in the first step, burn frequency, timing, regime, and occurrence, a single model with $\triangle \mathrm{AICc} \leq 2$ was retained: $\Phi$ ( occurrence+timing+sun+humid) $p$ ( occurrence+regime +precip+tmin+sun $) \quad f(\sim$ occurrence + frequency+tmed + sun + hu mid+tmin $)($ AICc $=5551.07$, deviance $=1869.47)$. In this model, all demographic parameters were influenced by the short-term effect of fire, survival was best explained by fire timing, capture by fire regime, and recruitment by fire frequency. The estimates of demographic parameters exhibited regular, cyclical patterns throughout the years (Fig. 6).

The probability of survival $(\Phi)$ varied seasonally, primarily as a function of insolation and air humidity, being lowest during the dry season (May to September), when insolation is highest and air humidity is lowest (Fig. 6, Table 3). $\Phi$ also varied significantly with the timing of burns, being lowest in the plot burned late in the dry season and similar in the other plots; in months with fire (short-term effect), $\Phi$ increased (Fig. 6, Table 3). The probability of capture $(p)$ varied inversely with $\Phi$, being highest in the dry season, primarily driven by lower precipitation and minimum air temperatures and higher insolation (Fig. 6, Table 3). $p$ also varied with the fire regime (interaction between fire timing and frequency), being lowest in the more extreme regimes, i.e., the control and the late biennial plots, and highest in the middle biennial plot; in months with fire, $p$ increased (Fig. 6, Table 3). Finally, recruitment ( $f$ ) peaked in the transition between 
late dry and early wet season, being primarily correlated with air temperature and negatively correlated with insolation (Fig. 6, Table 3). f varied significantly with burn frequency, being lowest in biennial plots and highest in the control plot, but differences were very small; $f$ increased in months when burns occurred (Fig. 6, Table 3).

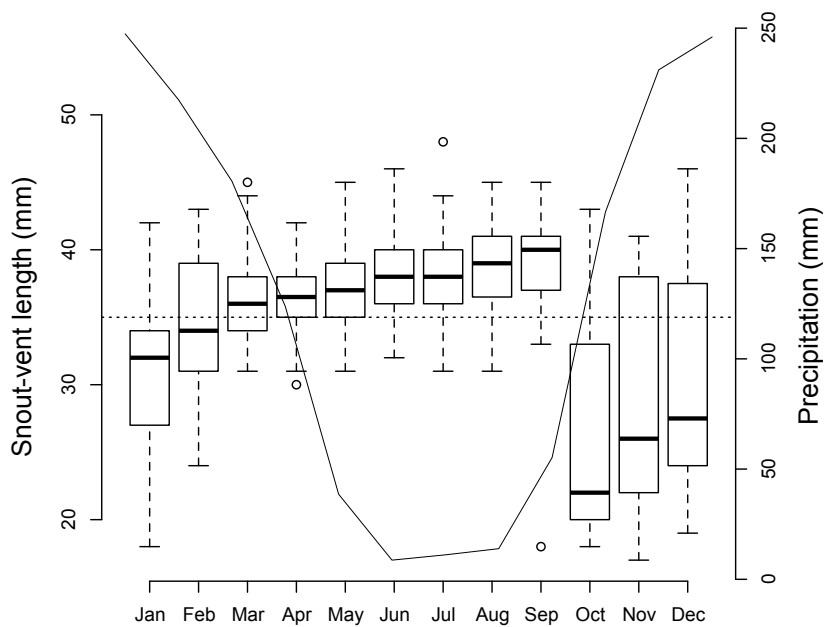

Figure 4. Monthly variation in precipitation and snout-vent length (SVL) of Micrablepharus atticolus captured from 2005 to 2013, in cerrado sensu stricto control and treatment plots of varying fire severity, in central Brazil. Boxplot depicts median (solid bar) and interquartile range (box). Whiskers extend as far as $1.5 \mathrm{x}$ the interquartile range or to minimum and maximum SVL. Dashed line indicates SVL at sexual maturity $(35 \mathrm{~mm})$. Curve represents average precipitation in Brasília, Distrito Federal, from 1961-1990 (Source: Instituto Nacional de Meteorologia - INMET).

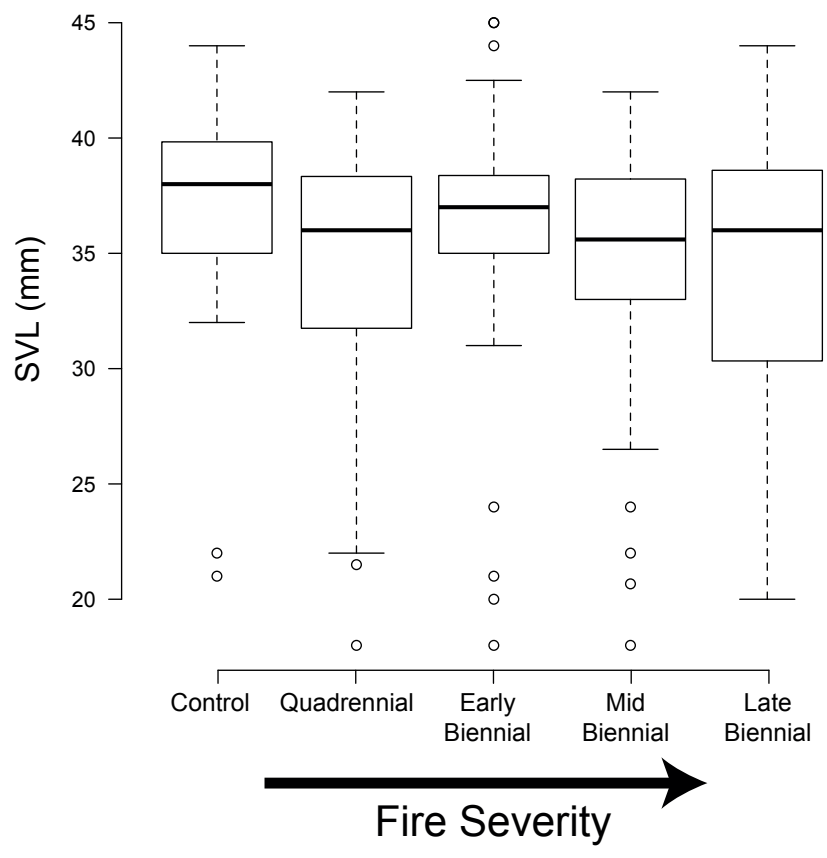

Figure 5. Snout-vent length (SVL) variation of Micrablepharus atticolus in cerrado sensu stricto control and treatment plots of varying fire severity in central Brazil. Boxplot depicts median (solid bar) and interquartile range (box). Whiskers extend as far as $1.5 x$ the interquartile range or to minimum and maximum SVL.
Table 3. Demographic analysis of Micrablepharus atticolus in plots subjected to controlled burns, in Brasília, Distrito Federal, Brazil, from November 2005 to March 2013. Values represent estimates of demographic parameters and coefficients of strata and covariates of the Pradel model $\Phi(\sim o c c u r r e n c e+t i m i n g+h u m i d+$ sun $) p(\sim o c c u r r e n c e+r e g i$ me+precip+sun+tmin $) \quad f(\sim$ occurrence+frequency+humid+sun+tmed+tmin) . Coefficients $(\beta) \Phi$ : probability of survival, $p$ : probability of capture, $f$ : per capita recruitment. Strata: burn frequency (control, quadrennial and biennial), timing (control, early, middle and late dry season), regime (control, quadrennial, early biennial, middle biennial and late biennial), and fire occurrence (yes, no).

\begin{tabular}{|c|c|c|}
\hline Parameter & Estimate ( \pm SD) & $\beta( \pm \mathbf{S E})$ \\
\hline \multicolumn{3}{|l|}{$\Phi$} \\
\hline Intercept (Control) & $0.917 \pm 0.101$ & $22.517 \pm 3.292$ \\
\hline Middle dry season & $0.918 \pm 0.103$ & $-0.023 \pm 0.350$ \\
\hline Early dry season & $0.907 \pm 0.112$ & $-0.222 \pm 0.352$ \\
\hline Late dry season & $0.887 \pm 0.134$ & $-0.458 \pm 0.352$ \\
\hline Fire occurrence & & $108.068 \pm 0.000$ \\
\hline With fire & $0.983 \pm 0.052$ & \\
\hline Without fire & $0.908 \pm 0.112$ & \\
\hline Relative air humidity & & $-0.149 \pm 0.028$ \\
\hline Insolation & & $-1.298 \pm 0.201$ \\
\hline \multicolumn{3}{|l|}{$p$} \\
\hline Intercept (Control) & $0.022 \pm 0.020$ & $-1.618 \pm 0.817$ \\
\hline Middle biennial & $0.075 \pm 0.061$ & $1.368 \pm 0.461$ \\
\hline Early biennial & $0.047 \pm 0.042$ & $0.850 \pm 0.475$ \\
\hline Late biennial & $0.032 \pm 0.029$ & $0.443 \pm 0.503$ \\
\hline Middle quadrennial & $0.045 \pm 0.040$ & $0.767 \pm 0.480$ \\
\hline Fire occurrence & & $-1.034 \pm 0.405$ \\
\hline With fire & $0.090 \pm 0.065$ & \\
\hline Without fire & $0.043 \pm 0.044$ & \\
\hline Precipitation & & $-0.082 \pm 0.031$ \\
\hline Insolation & & $0.090 \pm 0.054$ \\
\hline Minimum air temperature & & $-0.197 \pm 0.032$ \\
\hline \multicolumn{3}{|l|}{$f$} \\
\hline Intercept (Control) & $0.157 \pm 0.237$ & $-13.797 \pm 6.439$ \\
\hline Biennial & $0.153 \pm 0.235$ & $0.202 \pm 0.347$ \\
\hline Quadrennial & $0.155 \pm 0.226$ & $0.051 \pm 0.352$ \\
\hline Fire occurrence & & $4.094 \pm 0.974$ \\
\hline With fire & $0.625 \pm 0.383$ & \\
\hline Without fire & $0.146 \pm 0.220$ & \\
\hline Relative air humidity & & $-0.095 \pm 0.035$ \\
\hline Insolation & & $-0.681 \pm 0.178$ \\
\hline Mean air temperature & & $0.810 \pm 0.212$ \\
\hline Minimum air temperature & & $0.224 \pm 0.147$ \\
\hline
\end{tabular}

\section{DISCUSSION}

The demography of the endemic Cerrado lizard, $M i-$ crablepharus atticolus, is influenced by both the marked seasonality of the Cerrado climate and the different fire regimes. Our results indicate the species has a well-defined reproductive cycle and that populations undergo a complete annual turnover. Micrablepharus atticolus is, thus, one of the few species of tetrapods known to have an annual lifespan (Bourlière, 1959; Karsten et al., 2008). Breeding takes place in the dry season, as indicated by 


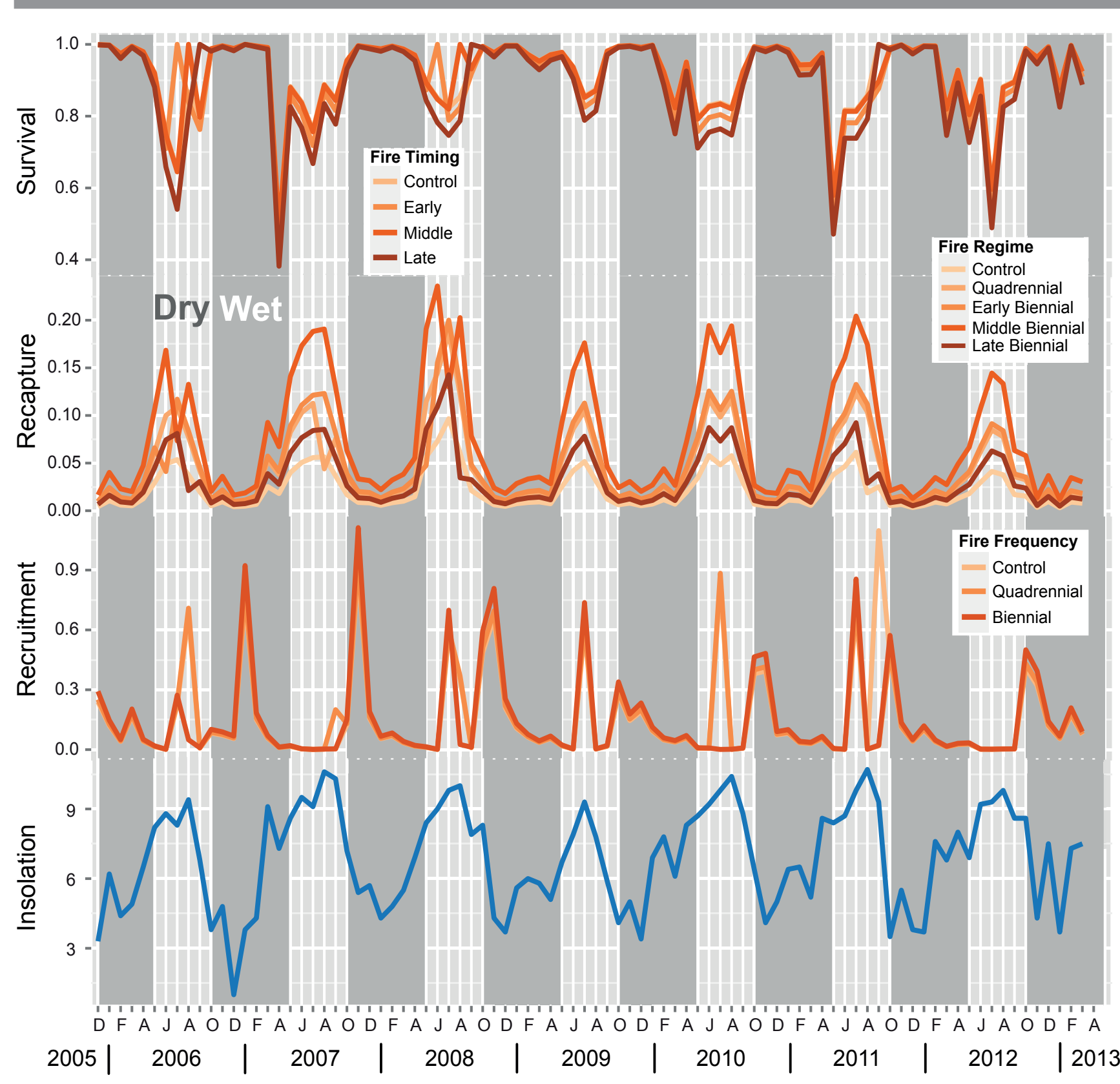

Figure 6. Estimates of apparent survival, capture and recruitment rates of Micrablepharus atticolus from cerrado sensu stricto control and treatment plots of varying fire severity in central Brazil, from 2005-2013. Blue line indicates the monthly variation of insolation (Source: RECOR meteorological station).

the presence of gravid females and a peak in the probability of captures, likely resulting from increased activity of adults. Juveniles hatch early in the wet season (as indicated by the distribution of SVL and by a peak in recruitment), grow, attain sexual maturity and reproduce in the next dry season, and then die (as indicated by a drop in survival), with practically no overlap among generations. These characteristics place the species in the small-bodied, early-maturing, small-clutched, and multiple-brooded category of lizard life histories (Tinkle et al., 1970; Dunham et al., 1988). Sympatric species of Cerrado lizards exhibit a variety of reproductive tactics, with most reproducing primarily during the rainy season, including Ameiva ameiva (Linnaeus 1758) (Colli, 1991), Mabuya frenata (Cope 1862) (Vrcibradic and Rocha, 1998), Polychrus acutirostris Spix 1825 (Garda et al., 2012), Tropidurus itambere Rodrigues 1987 (Van Sluys, 1993), and T. torquatus (Wied-Neuwied 1820) (Wiederhecker et al., 2002), whereas others breed in the dry season, such as Cnemidophorus ocellifer (Spix 1825) (Mesquita and Colli, 2003) and Gymnodactylus amarali Barbour 1925 (Colli et al., 2003). This variation likely results from the interaction between phylogenetic conservatism and fluctuating environmental conditions (e.g., water and temperature) and resources (e.g., food availability) (Colli et al., 1997). 
The ecology of gymnophthalmid lizards is very poorly known, but the available data indicates that the small clutch size of 1-2 eggs (Duellman, 1978; Avila-Pires, 1995) is a phylogenetically conserved trait (Vitt and Caldwell, 2009). On the other hand, the length of the breeding season is quite variable, being continuous in Neusticurus ecpleopus (Cope 1876) from the Amazon rainforest (e.g., Sherbrooke, 1975) and Vanzosaura multiscutata (Amaral 1933) from the semi-arid Caatinga (Vitt, 1982), and seasonal in Cercosaura schreibersii Wiegmann 1834 from the Pampas and Araucaria forest (Balestrin et al., 2010), and Leposoma rugiceps (Cope 1869) and Gymnophthalmus speciosus (Hallowell 1861) from Panama city (Telford, 1971). Among the climate variables we analyzed, insolation was the most important, being the best predictor of temporal variation in SVL and the only simultaneous predictor of survival, recapture, and recruitment. Micrablepharus atticolus has a generalist diet, consisting of a variety of arthropods (Vieira et al., 2000; Gainsbury and Colli, 2003) and, overall, insect abundance is highest during the rainy season in the study area (Pinheiro et al., 2002). Since the reproductive activity of $M$. atticolus peaks during the dry season, its reproductive cycle is likely not driven by food availability for adults (Colli et al., 1997), but presumably by a combination of suitable conditions for adult activity and egg development in the drier months, and for juvenile growth during the wet season.

Our results indicate that the short-term effects of fires are beneficial for populations of Micrablepharus atticolus: in months with fires, there was an increase in survival, captures, and recruitment. Cerrado fires spread rapidly and consume primarily the herbaceous layer, with soil temperature changes at or below a depth of $5 \mathrm{~cm}$ being negligible (Miranda et al., 2002, 2009). Cerrado lizards (even arboreal species) rely on shelters to evade the passage of fire and direct mortality caused by fire is rare or nonexistent (Costa et al., 2013). Most Cerrado herbs resprout and flower vigorously a few days or weeks after fires (Miranda et al., 2002, 2009), and this burst of productivity contributes to increased abundance of insects (Prada et al., 1995; Vieira et al., 1996; Uehara-Prado et al., 2010; Lopes and Vasconcelos, 2011; Lepesqueur et al., 2012) and, presumably, to increased food availability for lizards. In addition, the increased soil exposure and heat flux after Cerrado fires (Castro-Neves and Miranda, 1996) may be beneficial to $M$. atticolus, given its preference for open habitats and high body temperatures (Vieira et al., 2000). Therefore, short-term post-fire changes in Cerrado are seemingly beneficial to populations of $M$. atticolus by creating favorable environmental conditions.

In the long run, however, fire regimes of increased intensity are detrimental to populations of Micrablepharus atticolus: survival was lowest in the plot burned late in the dry season, the probability of capture was low in the late biennial plot, and recruitment was lowest in biennial plots. Late dry season fires in Cerrado attain highest intensity, since most of the combustible fuel is dry, relative air humidity is at its lowest, and wind speed is at its highest (Mistry, 1998; Ramos et al., 2009). High fire frequencies result in lower recruitment and higher mortality of woody plants, leading to more open Cerrado physiognomies with decreased abundance and richness of woody plants (Hoffmann, 1996; 1999; Moreira, 2000; Hoffmann and Moreira, 2002). In addition, high fire frequencies favor the growth of grasses and a reduction of the leaf litter (Mistry, 1998; Hoffmann and Moreira, 2002), soil moisture, nutrient pools and nutrient fluxes (Kauffman et al., 1994; Nardoto et al., 2006; Valenti et al., 2008). As a consequence, high fire frequencies result in decreased abundance of arthropods (Diniz et al., 2011; Freire and Motta, 2011), including those that dwell in the leaf litter (Vasconcelos et al., 2009). Altogether, these changes result in less-favorable microclimate conditions (reduced leaf litter and moisture) and diminished food resources for $M$. atticolus.

Fire suppression had mixed effects on the demography of Micrablepharus atticolus: survival and recruitment were high, but the probability of capture was lowest in the control (unburned) plot. The total number of captures and recaptures in the control plot was also significantly lower than in all other plots. Fire suppression creates shadier microenvironments, due to increased abundance and richness of woody plants (Hoffmann, 1996; 1999; Moreira, 2000; Hoffmann and Moreira, 2002), which are seemingly unsuitable to Micrablepharus atticolus populations. Therefore, either fire suppression or fire regimes of increased severity seem detrimental to populations of M. atticolus.

Present-day fire regimes in the Cerrado pose contrasting challenges to its biodiversity (Coutinho, 1990; Pivello, 2011). In protected areas, where fires are not allowed and where fire-management plans are often lacking, there is a tendency for the woody vegetation to become denser and taller, resulting in shadier and moister environments (Durigan and Ratter, 2006; Soares et al., 2006). This leads to increased build up of combustible fuel and, when fires occur, they tend to be severe and burn large tracts of the landscape. In practice, even in protected areas of Cerrado fires occur every 3-6 years, when the probability of burning as a function of time since the last fire peaks, highlighting the inefficacy of fire-suppression measures (França et al., 2007; Pereira et al., 2014). Conversely, outside protected areas, human-induced fires occur at a high frequency, often annually, leading to a reduction in woody vegetation and favoring the herbaceous layer, resulting in more open and dry environments. More recently, this scenario has worsened due to positive feedbacks between carbon emissions from burns and climate change, which lead to increasingly hotter and drier, fireprone landscapes, in an escalating spiral (Arantes et al., 
2012; Araújo et al., 2012). Our long-term study indicates that both fire-suppression and uncontrolled highfrequency burns are detrimental to populations of the endemic Cerrado lizard, Micrablepharus atticolus. Given their small body size, limited mobility and ectothermy, Cerrado amphibians and reptiles could show similar responses. Adequate fire management, through prescribed burns, conducted at adequate temporal and spatial scales is therefore warranted, to reduce the severity of burns in Cerrado (Pivello, 2011; Pereira et al., 2014). This should include a reduction in the frequency or a shift towards the early dry season in the timing of burns in more open areas, and controlled, small-scale fires in mosaic arrangement to preclude the excessive accumulation of combustible fuel in denser physiognomies.

\section{ACKNOWLEDGEMENTS}

We thank the staff of RECOR for being supportive during the development of fieldwork. GRC thanks Coordenação de Apoio à Formação de Pessoal de Nível Superior (CAPES), Conselho Nacional do Desenvolvimento Científico e Tecnológico (CNPq), and Fundação de Apoio à Pesquisa do Distrito Federal (FAPDF) for financial support. HCS thanks CAPES and CNPq for undergraduate and graduate scholarships.

\section{REFERENCES}

Amaral A. 1933. Estudos sobre lacertílios neotropicos. I. Novos gêneros e espécies de lagartos do Brasil. Memórias do Instituto Butantan 7:51-74.

Andersen A.N., Cook G.D., Williams R.J. 2003. Fire in Tropical Savannas: The Kapalga Experiment. Springer-Verlag, New York.

Andersen A.N., Cook G.D., Corbett L.K., Douglas M.M., Eager R.W., Russell-Smith J., Setterfield S.A., ... Woinarski J.C.Z. 2005. Fire frequency and biodiversity conservation in Australian tropical savannas: implications from the Kapalga fire experiment. Austral Ecology 30:155-167. doi:10.1111/J.1442-9993.2005.01441.X

Anderson D.R. 2001. The need to get the basics right in wildlife field studies. Wildlife Society Bulletin 29:1294-1297.

Arantes A.E., Ferreira L.G., Araújo F.M. 2012. Burnings in the Brazilian savanna: a preliminary analysis on key biophysical drivers using MODIS and TRMM data. In International I, ed. IEEE International Geoscience and Remote Sensing Symposium (IGARSS). Munich, 6158-6160.

Araújo F.M., Ferreira L.G., Arantes A.E. 2012. Distribution patterns of burned areas in the Brazilian biomes: an analysis based on satellite data for the 2002-2010 period. Remote Sensing 4:19291946. doi:10.3390/Rs4071929

Attum O.A., Eason P.K. 2006. Effects of vegetation loss on a sand dune lizard. Journal of Wildlife Management 70:27-30. doi:10.2193/0022-541x(2006)70[27:Eovloa]2.0.Co;2

Avila-Pires T.C.S. 1995. Lizards of Brazilian Amazonia (Reptilia: Squamata). Zoologische Verhandelingen, Leiden 299:1-706.

Bailey L.L., Simons T.R., Pollock K.H. 2004. Spatial and temporal variation in detection probability of plethodon salamanders using the robust capture-recapture design. Journal of Wildlife Management 68:14-24. doi:10.2193/0022-541x(2004)068[0014:Satvid]2.0.Co;2
Balestrin R.L., Cappellari L.H., Outeiral A.B. 2010. Reproductive biology of Cercosaura schreibersii (Squamata, Gymnophthalmidae) and Cnemidophorus lacertoides (Squamata, Teiidae) in SulRiograndense Shield, Brazil. Biota Neotropica 10:131-139. doi:10.1590/S1676-06032010000100013

Banks S.C., Blyton M.D.J., Blair D., McBurney L., Lindenmayer D.B. 2012. Adaptive responses and disruptive effects: how major wildfire influences kinship-based social interactions in a forest marsupial. MolecularEcology21:673-684.doi:10.1111/J.1365-294x.2011.05282.X

Barbour T. 1925. New Neotropical lizards. Proceedings of the Biological Society of Washington 38:101-102.

Bartón K. 2014. MuMIn: Multi-model inference. Available from: http://CRAN.R-project.org/package=MuMIn.

Bates D., Maechler M., Bolker B., Walker S. 2014. lme4: Linear mixed-effects models using Eigen and S4. Available from: http:// CRAN.R-project.org/package $=$ lme 4 .

Bond W.J., Keeley J.E. 2005. Fire as a global 'herbivore': the ecology and evolution of flammable ecosystems. Trends in Ecology \& Evolution 20:387-394. doi:10.1016/J.Tree.2005.04.025

Bond W.J., Woodward F.I., Midgley G.F. 2005. The global distribution of ecosystems in a world without fire. New Phytologist 165:525-537. doi:10.1111/J.1469-8137.2004.01252.X

Booysen P.D.V., Tainton N.M. 1984. Ecological Effects of Fire in South African Ecosystems. Springer-Verlag, Berlin.

Bourlière F. 1959. Lifespan of mammalian and bird populations in nature. Pp. 90-105, in: Wolstenholme G.E.W., O'Connor M. (Eds.), Ciba Foundation Colloquia on Ageing. Vol. 5. The Lifespan of Animals. J. \& A. Churchill Ltd., London.

Bowman D.M.J.S., Balch J.K., Artaxo P., Bond W.J., Carlson J.M., Cochrane M.A., ... Pyne S.J. 2009. Fire in the Earth system. Science 324:481-484. doi:10.1126/Science.1163886

Bowman D.M.J.S., Balch J., Artaxo P., Bond W.J., Cochrane M.A., D'Antonio C.M., ... Swetnam T.W. 2011. The human dimension of fire regimes on Earth. Journal of Biogeography 38:2223-2236. doi:10.1111/J.1365-2699.2011.02595.X

Brisson J.A., Strasburg J.L., Templeton A.R. 2003. Impact of fire management on the ecology of collared lizard (Crotaphytus collaris) populations living on the Ozark Plateau. Animal Conservation 6:247-254. doi:10.1017/S1367943003003305

Burnham K.P., Anderson D.R. 2002. Model Selection and MultiModel Inference. Springer-Verlag, New York.

Burnham K.P., Anderson D.R. 2004. Multimodel inference: understanding AIC and BIC in model selection. Sociological Methods \& Research 33:261-304.

Bury R.B. 2004. Wildfire, fuel reduction, and herpetofaunas across diverse landscape mosaics in northwestern forests. Conservation Biology 18:968-975. doi:10.1111/J.1523-1739.2004.00522.X

Cano P.D., Leynaud G.C. 2009. Effects of fire and cattle grazing on amphibians and lizards in northeastern Argentina (humid Chaco). European Journal of Wildlife Research 56:411-420. doi:10.1007/ s10344-009-0335-7

Carpenter S.R. 1990. Large-scale perturbations: opportunities for innovation. Ecology 71:2038-2043.

Castro-Neves B.M., Miranda H.S. 1996. Efeitos do fogo no regime térmico do solo de um campo sujo de Cerrado. Pp. 20-30, in: Miranda H.S., Saito C.H., Dias B.F.S. (Eds.), Impactos de Queimadas em Áreas de Cerrado e Restinga. Brasília, Universidade de Brasília.

Cavitt J.F. 2000. Fire and a tallgrass prairie reptile community: Effects on relative abundance and seasonal activity. Journal of Herpetology 34:12-20. doi:10.2307/1565233

Choquet R., Lebreton J.D., Gimenez O., Reboulet A.M., Pradel R. 2009. U-CARE: Utilities for performing goodness of fit tests and manipulating CApture-REcapture data. Ecography 32:1071-1074.

Chuvieco E. 2009. Earth Observation of Wildland Fires in Mediterranean Ecosystems. Springer-Verlag, Berlin.

Clarke M.F. 2008. Catering for the needs of fauna in fire management: science or just wishful thinking? Wildlife Research 35:385-394. doi:10.1071/Wr07137 
Cochrane M.A. 2009. Tropical Fire Ecology: Climate Change, Land Use, and Ecosystem Dynamics. Springer and Praxis Publishing Ltd., Chichester.

Colli G.R. 1991. Reproductive ecology of Ameiva ameiva (Sauria, Teiidae) in the Cerrado of central Brazil. Copeia 1991:1002-1012.

Colli G.R., Peres A.K., Zatz M.G. 1997. Foraging mode and reproductive seasonality in tropical lizards. Journal of Herpetology 31:490-499.

Colli G.R., Bastos R.P., Araújo A.F.B. 2002. The character and dynamics of the Cerrado herpetofauna. Pp. 223-241, in: Oliveira P.S. and Marquis R.J. (Eds.), The Cerrados of Brazil: Ecology and Natural History of a Neotropical Savanna. New York, Columbia University Press.

Colli G.R., Mesquita D.O., Rodrigues P.V.V., Kitayama K. 2003. Ecology of the gecko Gymnodactylus geckoides amarali in a Neotropical Savanna. Journal of Herpetology 37:694-706.

Conedera M., Tinner W., Neff C., Meurer M., Dickens A.F., Krebs P. 2009. Reconstructing past fire regimes: methods, applications, and relevance to fire management and conservation. Quaternary Science Reviews 28:555-576. doi:10.1016/J.Quascirev.2008.11.005

Cope E.D. 1862. Contributions to Neotropical Saurology. Proceedings of the Academy of Natural Sciences of Philadelphia 14:176-188.

Cope E.D. 1868. Sixth contribution to the herpetology of tropical America. Proceedings of the Academy of Natural Sciences of Philadelphia 20:305-313.

Cope E.D. 1876. "On the Batrachia and Reptilia of Costa Rica"; "On the Batrachia and Reptilia collected by Dr. John M. Branford during the Nicaraguan Canal Survey of 1874"; and "Report on the Reptiles brought by Professor James Orton from the middle and upper Amazon and western Peru". Journal of the Academy of Natural Sciences of Philadelphia 8:93-183.

Costa B.M., Pantoja D.L., Vianna M.C.M., Colli G.R. 2013. Direct and short-term effects of fire on lizard assemblages from a Neotropical savanna hotspot. Journal of Herpetology 47:502-510. doi:10.1670/12-043

Coutinho L.M. 1990. Fire in the ecology of the Brazilian Cerrado. Pp. 82-105, in: Goldammer J.G. (Ed.), Fire in the Tropical Biota: Ecosystem Processes and Global Challenges. Springer-Verlag, Berlin.

Crawley M.J. 2013. The R Book. John Wiley \& Sons Ltd., Chichester.

Cunningham S.C., Babb R.D., Jones T.R., Taubert B.D., Vega R. 2002. Reaction of lizard populations to a catastrophic wildfire in a central Arizona mountain range. Biological Conservation 107:193201. doi:10.1016/S0006-3207(02)00064-2

Dempster A.P., Laird N.M., Rubin D.B. 1977. Maximum likelihood from incomplete data via the EM algorithm. Journal of the Royal Statistical Society, Series B 39:1-38.

Di Bella C.M., Jobbagy E.G., Paruelo J.M., Pinnock S. 2006. Continental fire density patterns in South America. Global Ecology and Biogeography 15:192-199. doi:10.1111/J.1466-822x.2006.00225.X

Diniz I.R., Marinho-Filho J., Machado R.B., Cavalcanti R.B. 2010. Cerrado: Conhecimento Científico Quantitativo como Subsídio para Ações de Conservação. Editora UnB, Brasília.

Diniz I.R., Higgins B., Morais H.C. 2011. How do frequent fires in the Cerrado alter the lepidopteran community? Biodiversity and Conservation 20:1415-1426.

Driscoll D.A., Henderson M.K. 2008. How many common reptile species are fire specialists? A replicated natural experiment highlights the predictive weakness of a fire succession model. Biological Conservation 141:460-471. doi:10.1016/J.Biocon.2007.10.016

Driscoll D.A., Lindenmayer D.B., Bennett A.F., Bode M., Bradstock R.A., Cary G.J., ... York A. 2010. Fire management for biodiversity conservation: Key research questions and our capacity to answer them. Biological Conservation 143:1928-1939. doi:10.1016/J.Biocon.2010.05.026

Duellman W.E. 1978. The biology of an equatorial herpetofauna in Amazonian Ecuador. Miscellaneous Publications of the Museum of Natural History, University of Kansas 65:1-352.
Dunham A.E., Miles D.B., Reznick D.N. 1988. Life history patterns in squamate reptiles. Pp. 441-552, in: Gans C., Huey R.B. (Eds.), Biology of the Reptilia. Volume 16. Ecology B. Defense and Life History. New York, A.R. Liss.

Durigan G., Ratter J.A. 2006. Successional changes in Cerrado and Cerrado/forest ecotonal vegetation in western São Paulo state, Brazil, 1962-2000. Edinburgh Journal of Botany 63:119-130.

Eby S., Ritchie M.E. 2013. The impacts of burning on Thomson's gazelles', Gazella thomsonii, vigilance in Serengeti National Park, Tanzania. African Journal of Ecology 51:337-342. doi:10.1111/ Aje.12044

Eiten G. 1972. The Cerrado vegetation of Brazil. The Botanical Review 38:201-341.

Faria A.S., Lima A.P., Magnusson W.E. 2004. The effects of fire on behaviour and relative abundance of three lizard species in an Amazonian savanna. Journal of Tropical Ecology 20:591-594. doi:10.1017/S0266467404001798

Fenner A.L., Bull C.M. 2007. Short-term impact of grassland fire on the endangered pygmy bluetongue lizard. Journal of Zoology 272:444-450. doi:10.1111/J.1469-7998.2007.00287.X

Ford W.M., Menzel M.A., McGill D.W., Laerm J., McCay T.S. 1999 Effects of a community restoration fire on small mammals and herpetofauna in the southern Appalachians. Forest Ecology and Management 114:233-243. doi:10.1016/S0378-1127(98)00354-5

França H., Neto M.B.R., Setzer A. 2007. O Fogo no Parque Nacional das Emas. Ministério do Meio Ambiente, Brasília, DF.

Freire G.D., Motta P.C. 2011. Effects of experimental fire regimes on the abundance and diversity of cursorial arachnids of Brazilian savannah (Cerrado biome). Journal of Arachnology 39:263-272.

Frizzo T.L.M., Bonizário C., Borges M.P., Vasconcelos H.L. 2011. Revisão dos efeitos do fogo sobre a fauna de formações savânicas do Brasil. Oecologia Australis 15:365-379. doi:10.4257/ oeco.2011.1502.13

Gainsbury A.M., Colli G.R. 2003. Lizard assemblages from natural cerrado enclaves in southwestern Amazonia: the role of stochastic extinctions and isolation. Biotropica 35:503-519. doi:10.1111/j.1744-7429.2003.tb00607.x

Galecki A., Burzykowski T. 2013. Linear Mixed Effects Models Using R. Springer Science+Business Media, New York.

Garda A.A., Costa G.C., Franca F.G.R., Giugliano L.G., Leite G.S., Mesquita D.O., ... Colli G.R. 2012. Reproduction, body size, and diet of Polychrus acutirostris (Squamata: Polychrotidae) in two contrasting environments in Brazil. Journal of Herpetology 46:2-8. doi:10.1670/10-288

Goldammer J.G. 1990. Fire in the Tropical Biota: Ecosystems Processes and Global Challenges. Springer-Verlag Berlin, Heidelberg.

Goldammer J.G., Furyaev V.V. 1996. Fire in Ecosystems of Boreal Eurasia. Springer Science+Business Media, Dordrecht.

Greenberg C.H., Waldrop T.A. 2008. Short-term response of reptiles and amphibians to prescribed fire and mechanical fuel reduction in a southern Appalachian upland hardwood forest. Forest Ecology and Management 255:2883-2893. doi:10.1016/J.Foreco.2008.01.064

Greenberg C.H., Neary D.G., Harris L.D. 1994. Effect of highintensity wildfire and silvicultural treatments on reptile communities in sand-pine scrub. Conservation Biology 8:1047-1057. doi:10.1046/J.1523-1739.1994.08041047.X

Griffiths A.D., Christian K.A. 1996. The effects of fire on the frillneck lizard (Chlamydosaurus kingii) in northern Australia. Australian Journal of Ecology 21:386-398. doi:10.1111/J.1442-9993.1996. Tb00625.X

Guimarães M., Doherty P.F., Munguía-Steyer R. 2014 Strengthening population inference in herpetofaunal studies by addressing detection probability. South American Journal of Herpetology 9:1-8. doi:10.2994/Sajh-D-13-00020.1

Hailey A. 2000. The effects of fire and mechanical habitat destruction on survival of the tortoise Testudo hermanni in northern Greece. Biological Conservation 92:321-333. doi:10.1016/ S0006-3207(99)00099-3 
Hallowell E. 1861 dated 1860. Report upon the Reptilia of the North Pacific Exploring Expedition, under command of Capt. John Rogers, U.S.N. Proceedings of the Academy of Natural Sciences of Philadelphia 12:480-510.

Hoffmann W.A. 1996. The effects of fire and cover on seedling establishment in a Neotropical savanna. Journal of Ecology 84:383393. doi:10.2307/2261200

Hoffmann W.A. 1999. Fire and population dynamics of woody plants in a Neotropical savanna: matrix model projections. Ecology 80:13541369. doi:10.1890/0012-9658(1999)080[1354:Fapdow]2.0.Co;2

Hoffmann W.A., Moreira A.G. 2002. The role of fire in population dynamics of woody plants. Pp. 159-177, in: Oliveira P.S., Marquis R.J. (Eds.), The Cerrados of Brasil: Ecology and Natural History of a Neotropical Savanna. Columbia University Press, New York.

Honaker J., King G., Blackwell M. 2011. Amelia II: A program for missing data. Journal of Statistical Software 45:1-47.

Hossack B.R., Lowe W.H., Ware J.L., Corn P.S. 2013. Disease in a dynamic landscape: Host behavior and wildfire reduce amphibian chytrid infection. Biological Conservation 157:293-299. doi:10.1016/J.Biocon.2012.09.013

Karpestam E., Merilaita S., Forsman A. 2012. Reduced predation risk for melanistic pygmy grasshoppers in post-fire environments. Ecology and Evolution 2:2204-2212. doi:10.1002/Ece3.338

Karsten K.B., Andriamandimbiarisoa L.N., Fox S.F., Raxworthy C.J. 2008. A unique life history among tetrapods: An annual chameleon living mostly as an egg. Proceedings of the National Academy of Sciences of the United States of America 105:8980-8984. doi:10.1073/Pnas.0802468105

Kasischke E.S., Stocks B.J. 2000. Fire, Climate Change, and Carbon Cycling in the Boreal Forest. Springer-Verlag, New York.

Kauffman J.B., Cummings D.L., Ward D.E. 1994. Relationships of fire, biomass and nutrient dynamics along a vegetation gradient in the Brazilian Cerrado. Journal of Ecology 82:519-531. doi: $10.2307 / 2261261$

Klink C.A., Machado R.B. 2005. Conservation of the Brazilian Cerrado. Conservation Biology 19:707-713.

Kochert M.N., Steenhof K., Carpenter L.B., Marzluff J.M. 1999. Effects of fire on golden eagle territory occupancy and reproductive success. Journal of Wildlife Management 63:773-780. doi:10.2307/3802790

Kortello A.D., Ham S.J. 2010. Movement and habitat selection by Argia vivida (Hagen) (Odonata, Coenagrionidae) in fuel-modified forest. Journal of Insect Conservation 14:133-140. doi:10.1007/ S10841-009-9233-2

Laake J.L. 2013. RMark: An R Interface for Analysis of CaptureRecapture Data with MARK. Seattle, WA: Alaska Fish. Sci. Cent., NOAA, Natl. Mar. Fish. Serv. 25.

Langford G.J., Borden J.A., Major C.S., Nelson D.H. 2007. Effects of prescribed fire on the herpetofauna of a southern Mississippi pine savanna. Herpetological Conservation and Biology 2:135-143.

Legge S., Murphy S., Heathcote J., Flaxman E., Augusteyn J., Crossman M. 2008. The short-term effects of an extensive and high-intensity fire on vertebrates in the tropical savannas of the central Kimberley, northern Australia. Wildlife Research 35:33. doi:10.1071/WR07016

Lepesqueur C., Morais H.C., Diniz I.R. 2012. Accidental fire in the Cerrado: its impact on communities of caterpillars on two species of Erythroxylum. Psyche 2012:1-7.

Letnic M., Dickman C.R., Tischler M.K., Tamayo B., Beh C.L. 2004. The responses of small mammals and lizards to post-fire succession and rainfall in arid Australia. Journal of Arid Environments 59:85114. doi:10.1016/J.Jaridenv.2004.01.014

Lindenmayer D.B., Wood J.T., MacGregor C., Michael D.R., Cunningham R.B., Crane M., ... Driscoll D.A. 2008. How predictable are reptile responses to wildfire? Oikos 117:1086-1097. doi:10.1111/J.0030-1299.2008.16683.X

Linnaeus C. 1758. Systema Naturae per Regna tria Naturae, secundum Classes, Ordines, Genera, Species, cum characteribus, differentiis, synonymus, locis. Ed. ro. Tomus I, Stockholm.
Little I.T., Hockey P.A.R., Jansen R. 2013. A burning issue: Fire overrides grazing as a disturbance driver for South African grassland bird and arthropod assemblage structure and diversity. Biological Conservation 158:258-270. doi:10.1016/J.Biocon.2012.09.017

Lopes C.T., Vasconcelos H.L. 2011. Fire increases insect herbivory in a Neotropical savanna. Biotropica 43:612-618. doi:10.1111/J.1744-7429.2011.00757.X

Lyet A., Cheylan M., Prodon R., Besnard A. 2009. Prescribed fire and conservation of a threatened mountain grassland specialist: a capture-recapturestudyon theOrsini'sviperintheFrenchalps.Animal Conservation 12:238-248. doi:10.1111/J.1469-1795.2009.00245.X

Masters P. 1996. The effects of fire-driven succession on reptiles in Spinifex grasslands at Uluru National Park, northern territory. Wildlife Research 23:39-48. doi:10.1071/Wr9960039

Mesquita D.O., Colli G.R. 2003. The ecology of Cnemidophorus ocellifer (Squamata, Teiidae) in a Neotropical savanna. Journal of Herpetology 37:498-509.

Miranda H.S. 2010. Efeitos do Regime do Fogo sobre a Estrutura de Comunidades de Cerrado: Resultados do Projeto Fogo. Ministério do Meio Ambiente; Instituto Brasileiro do Meio Ambiente e dos Recursos Naturais Renováveis; Centro Nacional de Prevenção e Combate aos Incêndios Florestais., Brasília.

Miranda H.S., Bustamante M.M.C., Miranda A.C. 2002. The fire factor. Pp. 51-68, in: Oliveira P.S., Marquis R.J. (Eds.), The Cerrados of Brazil: Ecology and natural history of a neotropical savanna. Columbia University Press, New York.

Miranda H.S., Sato M.N., Nascimento W.N., Aires F.S. 2009. Fires in the Cerrado, the Brazilian savanna. Pp. 427-450, in: Cochrane M.A. (Ed.) Tropical Fire Ecology: Climate Change, Land Use, and Ecosystem Dynamics. Springer and Praxis Publishing Ltd., Chichester.

Miranda H.S., Sato M.N., Andrade S.M.A., Neves B.M.C., Quesada C.A.N., Andrade L.A.Z., ... Maia J.M.F. 2011. Projeto Fogo. Pp. 163-177, in: Ribeiro M.L. (Ed.) Reserva Ecológica do IBGE: Biodiversidade Terrestre, Vol. 1. IBGE, Rio de Janeiro.

Mistry J. 1998. Fire in the Cerrado (savannas) of Brazil: an ecological review. Progress in Physical Geography 22:425-448. doi:10.1177/030913339802200401

Mistry J., Bizerril M. 2011. Por que é importante entender as interrelações entre pessoas, fogo e áreas protegidas? Biodiversidade Brasileira 1:40-49.

Mittermeier R.A., Myers N., Thomsen J.B., da Fonseca G.A.B., Olivieri S. 1998 . Biodiversity hotspots and major tropical wilderness areas: approaches to setting conservation priorities. Conservation Biology 12:516-520. doi:10.1046/j.1523-1739.1998.012003516.x

Moranz R.A., Fuhlendorf S.D., Engle D.M. 2014. Making sense of a prairie butterfly paradox: The effects of grazing, time since fire, and sampling period on regal fritillary abundance. Biological Conservation 173:32-41. doi:10.1016/J.Biocon.2014.03.003

Moreira A.G. 2000. Effects of fire protection on savanna structure in central Brazil. Journal of Biogeography 27:1021-1029. doi:10.1046/J.1365-2699.2000.00422.X

Moreno J.M., Oechel W.C. 1994. The Role of Fire in MediterraneanType Ecosystems. Springer-Verlag, New York.

Moseley K.R., Castleberry S.B., Schweitzer S.H. 2003 Effects of prescribed fire on herpetofauna in bottomland hardwood forests. Southeastern Naturalist 2:475-486. doi:10.1656/1528-7092(2003)002[0475:Eopfoh]2.0.Co;2

Mushinsky H.R. 1985. Fire and the Florida sandhill herpetofaunal community, with special attention to responses of Cnemidophorus sexlineatus. Herpetologica 41:333-342.

Mushinsky H.R. 1992. Natural history and abundance of southeastern five-lined skinks, Eumeces inexpectatus, on a periodically burned sandhill in Florida. Herpetologica 48:307-312.

Myers N., Mittermeier R.A., Mittermeier C.G., da Fonseca G.A.B., Kent J. 2000. Biodiversity hotspots for conservation priorities. Nature 403:853-858. doi:10.1038/35002501 
Nardoto G.B., Bustamante M.M.D., Pinto A.S., Klink C.A. 2006. Nutrient use efficiency at ecosystem and species level in savanna areas of central Brazil and impacts of fire. Journal of Tropical Ecology 22:191-201. doi:10.1017/S0266467405002865

Nicholson E., Lill A., Andersen A. 2006. Do tropical savanna skink assemblages show a short-term response to low-intensity fire? Wildlife Research 33:331-338. doi:10.1071/Wr05067

Nimer E. 1989. Climatologia do Brasil. IBGE, Departamento de Recursos Naturais e Estudos Ambientais, Rio de Janeiro.

Nogueira C.C. 2006. Diversidade e padrões de distribuição da fauna de lagartos do Cerrado. Universidade de São Paulo.

O'kane C.A.J., Page B.R., Macdonald D.W. 2014. Differing influences of resource availability on the demographics and habitat selection of wildebeest compared with impala. Journal of Tropical Ecology 30:189-198. doi:10.1017/S0266467414000133

Oksanen L. 2001. Logic of experiments in ecology: is pseudoreplication a pseudoissue? Oikos 94:27-38. doi:10.1034/j.1600-0706.2001.11311.x

Oliveira P.S., Marquis R.J. 2002. The Cerrados of Brazil. Ecology and Natural History of a Neotropical Savanna. Columbia University Press, New York.

Pantoja D.L. 2007. Efeitos do fogo sobre a taxocenose de lagartos em áreas de cerrado sensu stricto no Brasil central. Unpublished Mestrado em Ecologia Dissertação de Mestrado, Universidade de Brasília.

Pausas J.G., Keeley J.E. 2009. A burning story: the role of fire in the history of life. Bioscience 59:593-601. doi:10.1525/Bio.2009.59.7.10

Pelegrin N., Bucher E.H. 2010. Long-term effects of a wildfire on a lizard assemblage in the Arid Chaco forest. Journal of Arid Environments 74:368-372. doi:10.1016/j.jaridenv.2009.09.009

Pereira A.C., Oliveira S.L.J., Pereira J.M.C., Turkman M.A.A. 2014. Modelling fire frequency in a Cerrado savanna protected area. Plos One 9:e102380. doi:10.1371/journal.pone.0102380

Perry R.W., Rudolph D.C., Thill R.E. 2009. Reptile and amphibian responsestorestoration offire-maintainedpinewoodlands.Restoration Ecology 17:917-927. doi:10.1111/J.1526-100x.2009.00521.X

Pianka E.R. 1996. Long-term changes in lizard assemblages in the Great Victoria Desert: dynamic habitat mosaics in response to wildfires. Pp. 191-215, in: Cody M.L., Smallwood J.A. (Eds.), LongTerm Studies of Vertebrate Communities. Academic Press, San Diego.

Pianka E.R., Goodyear S.E. 2012. Lizard responses to wildfire in arid interior Australia: Long-term experimental data and commonalities with other studies. Austral Ecology 37:1-11. doi:10.1111/j.1442-9993.2010.02234.x

Pinheiro F., Diniz I.R., Coelho D., Bandeira M.P.S. 2002. Seasonal pattern of insect abundance in the Brazilian Cerrado. Austral Ecology 27:132-136. doi:10.1046/j.1442-9993.2002.01165.x

Pivello V.R. 2011. The use of fire in the Cerrado and Amazonian rainforests of Brazil: past and present. Fire Ecology 7:24-39. doi:10.4996/Fireecology.0701024

Pivello V.R., Oliveras I., Miranda H.S., Haridasan M., Sato M.N., Meirelles S.T. 2010. Effect of fires on soil nutrient availability in an open savanna in Central Brazil. Plant and Soil 337:111-123. doi:10.1007/s11104-010-0508-x

Popgeorgiev G. 2008. The effects of a large-scale fire on the demographic structure of a population of Hermann's (Testudo hermanni boettgeri Mojsisovics, 1889) and spur-thighed (Testudo graeca ibera Pallas, 1814) tortoises in eastern Rhodopes Mountains, Bulgaria. Historia naturalis bulgarica 19:115-127.

Prada M., Marini-Filho O.J., Price P.W. 1995. Insects in flower heads of Aspilia foliacea (Asteraceae) after a fire in a central Brazilian savanna: Evidence for the plant vigor hypothesis. Biotropica 27:513518. doi:10.2307/2388965

R Core Team. 2014. R: A Language and Environment for Statistical Computing. Available from: www.R-project.org.

Radford I.J., Andersen A.N. 2012. Effects of fire on grass-layer savanna macroinvertebrates as key food resources for insectivorous vertebrates in northern Australia. Austral Ecology 37:733-742. doi:10.1111/J.1442-9993.2012.02413.X

Ramos A.M., dos Santos L.A.R., Fortes L.T.G. 2009. Normais Climatológicas do Brasil 1961-1990. INMET, Brasília, DF.

Ramos-Neto M.B., Pivello V.R. 2000. Lightning fires in a Brazilian savanna National Park: rethinking management strategies. Environmental Management 26:675-684. doi:10.1007/ s002670010124

Redford K.H., Fonseca G.A.B. 1986. The role of gallery forests in the zoogeography of the Cerrado non-volant mammalian fauna. Biotropica 18:126-135. doi:10.2307/2388755

Ribeiro J.F., Walter B.M.T. 1998. Fitofisionomias do bioma Cerrado. Pp. 89-166, in: Sano S.M., Almeida S.P. (Eds.), Cerrado: Ambiente e Flora. Planaltina, EMBRAPA.

Rodrigues M.T. 1987. Sistemática, ecologia e zoogeografia dos Tropidurus do grupo torquatus ao sul do rio Amazonas (Sauria, Iguanidae). Arquivos de Zoologia 31:105-230.

Rodrigues M.T. 1996. A new species of lizard, genus Micrablepharus (Squamata: Gymnophthalmidae), from Brazil. Herpetologica 52:535-541.

Roebroeks W., Villa P. 2011. On the earliest evidence for habitual use of fire in Europe. Proceedings of the National Academy of Sciences of the United States of America 108:5209-5214. doi:10.1073/ Pnas.1018116108

Rota C.T., Millspaugh J.J., Rumble M.A., Lehman C.P., Kesler D.C. 2014. The role of wildfire, prescribed fire, and mountain pine beetle infestations on the population dynamics of BlackBacked Woodpeckers in the Black Hills, South Dakota. Plos One 9. doi:10.1371/journal.pone.0094700

Rubin D.B. 1996. Multiple imputation after $18+$ years. Journal of the American Statistical Association 91:473-489.

Russell K.R., Van Lear D.H., Guynn D.C. 1999. Prescribed fire effects on herpetofauna: review and management implications. Wildlife Society Bulletin 27:374-384.

Ruthven D.C., Kazmaier R.T., Janis M.W. 2008. Short-term response of herpetofauna to various burning regimes in the south Texas plains. Southwestern Naturalist 53:480-487. doi:10.1894/Wl-17.1

Santos M.G., Nogueira C., Giugliano L.G., Colli G.R. 2014 Landscape evolution and phylogeography of Micrablepharus atticolus (Squamata, Gymnophthalmidae), an endemic lizard of the Brazilian Cerrado. Journal of Biogeography 41:1506-1519. doi:10.1111/ jbi.12291

Sanz-Aguilar A., Anadon J.D., Gimenez A., Ballestar R., Gracia E., Oro D. 2011. Coexisting with fire: The case of the terrestrial tortoise Testudo graeca in Mediterranean shrublands. Biological Conservation 144:1040-1049. doi:10.1016/J.Biocon.2010.12.023

Secretariat of the Convention on Biological Diversity. 2001. Impacts of human-caused fires on biodiversity and ecosystem functioning, and their causes in tropical, temperate and boreal forest biomes. SCBD, Montreal.

Sherbrooke W.C. 1975. Reproductive cycle of a tropical teiid lizard, Neusticurus ecpleopus Cope. Biotropica 7:194-207.

Simon M.F., Grether R., de Queiroz L.P., Skema C., Pennington R.T., Hughes C.E. 2009. Recent assembly of the Cerrado, a Neotropical plant diversity hotspot, by in situ evolution of adaptations to fire. Proceedings of the National Academy of Sciences of the United States of America 106:20359-20364.

Singh S., Smyth A.K., Blomberg S.P. 2002. Effect of a control burn on lizards and their structural environment in a eucalypt openforest. Wildlife Research 29:447-454. doi:10.1071/WR01015

Smith A.L., Bull C.M., Driscoll D.A. 2012. Post-fire succession affects abundance and survival but not detectability in a knobtailed gecko. Biological Conservation 145:139-147. doi:10.1016/j. biocon.2011.10.023

Soares J.J., Souza M.H.A.O., Lima M.I.S. 2006. Twenty years of post-fire plant succession in a "Cerrado", São Carlos, SP, Brazil. Brazilian Journal of Biology 66:587-602. doi:10.1590/ S1519-69842006000400003 
Spix J.B. 1825. Animalia nova sive species novae lacertarum, quas in itinere per Brasiliam anis MDCCCXVII-MDCCCXX jussu et auspiciis Maximiliani Josephi I. Hübschmanni, Monachii, France.

Telford S.R. 1971. Reproductive patterns and relative abundance of two microteiid lizard species in Panama. Copeia 1971:670-675.

Templeton A.R., Brazeal H., Neuwald J.L. 2011. The transition from isolated patches to a metapopulation in the eastern collared lizard in response to prescribed fires. Ecology 92:1736-1747.

Tinkle D.W., Wilbur H.M., Tilley S.G. 1970. Evolutionary strategies in lizard reproduction. Evolution 24:55-74.

Uehara-Prado M., Bello A.D., Fernandes J.D., Santos A.J., Silva I.A., Cianciaruso M.V. 2010. Abundance of epigaeic arthropods in a Brazilian savanna under different fire frequencies. Zoologia 27:718-724. doi:10.1590/S1984-46702010000500008

Valenti M.W., Cianciaruso M.V., Batalha M.A. 2008. Seasonality of litterfall and leaf decomposition in a Cerrado site. Brazilian Journal of Biology 68:459-465. doi:10.1590/S1519-69842008000300002

Valentine L.E., Schwarzkopf L. 2009. Effects of weedmanagement burning on reptile assemblages in Australian tropical savannas. Conservation Biology 23:103-113. doi:10.1111/J.1523-1739.2008.01074.X

Van Sluys M. 1993. The reproductive cycle of Tropidurus itambere (Sauria, Tropiduridae) in southeastern Brazil. Journal of Herpetology 27:28-32.

Van Wilgen B.W., Richardson D.M., Kruger F.J., van Hensbergen H.J. 1992. Fire in South African Mountain Fynbos: Ecosystem, Community and Species Response at Swartboskloof. Heidelberg: Springer-Verlag Berlin.

Vasconcelos H.L., Pacheco R., Silva R.C., Vasconcelos P.B., Lopes C.T., Costa A.N., Bruna E.M. 2009. Dynamics of the leaf-litter arthropod fauna following fire in a Neotropical woodland savanna. Plos One 4:e7762. doi:10.1371/journal.pone.0007762

Veblen T.T., Baker W.L., Montenegro G., Swetnem T.W. 2003. Fire and Climatic Change in Temperate Ecosystems of the Western Americas. Springer-Verlag, New York.

Vieira E.M., Andrade I., Price P.W. 1996. Fire effects on a Palicourea rigida (Rubiaceae) gall midge: A test of the plant vigor hypothesis. Biotropica 28:210-217. doi:10.2307/2389075

Vieira G.H.C., Mesquita D.O., Péres Jr A.K., Kitayama K., Colli G.R. 2000. Micrablepharus atticolus (NCN). Natural history. Herpetological Review 31:241-242.

Vitt L.J. 1982. Sexual dimorphism and reproduction in the microteiid lizard, Gymnophthalmus multiscutatus. Journal of Herpetology 16:325-329. doi:10.2307/1563730
Vitt L.J. 1991. An introduction to the ecology of Cerrado lizards. Journal of Herpetology 25:79-90.

Vitt L.J., Caldwell J.P. 1993. Ecological observations on Cerrado lizards in Rondônia, Brazil. Journal of Herpetology 27:46-52.

Vitt L.J., Caldwell J.P. 2009. Herpetology. An Introductory Biology of Amphibians and Reptiles. Elsevier, Burlington.

Vrcibradic D., Rocha C.F.D. 1998. Reproductive cycle and life-history traits of the viviparous skink Mabuya frenata in southeastern Brazil. Copeia 1998:612-619. doi:10.2307/1447791

Webb J.K., Shine R. 2008. Differential effects of an intense wildfire on survival of sympatric snakes. Journal of Wildlife Management 72:1394-1398. doi:10.2193/2007-515

Webb J.K., Shine R., Pringle R.M. 2005. Canopy removal restores habitat quality for an endangered snake in a fire suppressed landscape. Copeia 2005:894-900.

White G.C., Burnham K.P. 1999. Program MARK: survival estimation from populations of marked animals. Bird Study 46:120-138.

Wied-Neuwied M. 1825. Beitrage zur Naturgeschichte von Brasilien. Landes-lndustrie, Welmar.

Wiederhecker H.C., Pinto A.C.S., Colli G.R. 2002. Reproductive ecology of Tropidurus torquatus (Squamata: Tropiduridae) in the highly seasonal Cerrado biome of central Brazil. Journal of Herpetology 36:82-91. doi:10.1670/0022-1511(2002)036[0082:RE OTTS]2.0.CO;2

Wiegmann A.F.A. 1834. Herpetologia Mexicana seu descriptio amphibiorum Novae Hispaniae quae itineribus comitis de Sack, Ferdinandi Deppe et Chr. Guil. Schiede in Museum Zoologicum Beroli-nense pervenerunt. Pars prima, Saurorum species amplectens, adiecto Systematis Saurorum Pro-dromo, additisque multis in hunc amphibiorum ordinem observationibus. C.G. Luderitz, Berlin.

Wilgers D.J., Horne E.A. 2007. Spatial variation in predation attempts on artificial snakes in a fire-disturbed tallgrass prairie. Southwestern Naturalist 52:263-270. doi:10.1894/0038-4909(2007)52[263:Svip ao]2.0.Co; 2

Woinarski J.C.Z., Armstrong M., Price O., McCartney J., Griffiths A.D., Fisher A. 2004. The terrestrial vertebrate fauna of Litchfield National Park, Northern Territory: monitoring over a 6-year period and response to fire history. Wildlife Research 31:587-596. doi:10.1071/Wr03077

Zar J.H. 2010. Biostatistical Analysis. Prentice Hall, Inc., Upper Saddle River, New Jersey.

Zhang P. 2003. Multiple imputation: Theory and method. International Statistical Review 71:581-592. 


\section{Capítulo 2: Correlatos ecológicos da autotomia caudal em Micrablepharus atticolus em uma savana Neotropical}

Autotomia caudal e regeneração são talvez as adaptações mais dramáticas entre os lagartos para aumentar a sobrevivência. Apesar de muitos estudos sobre o assunto, a significância ecológica das taxas de autotomia caudal em populações naturais permanece elusiva, devido às dificuldades em controlar vários fatores contraditórios e à falta de dados demográficos acurados. Baseados em um estudo de captura e recaptura, nós investigamos os determinantes ecológicos das taxas de autotomia caudal em Micrablepharus atticolus, um lagarto de cauda azul do Cerrado. Nós testamos se o hábitat (representando a intensidade de predação), a ontogenia e o sexo influenciavam as taxas de autotomia, e também se as taxas de autotomia influenciavam a condição corporal dos indivíduos. Nós encontramos que as taxas de autotomia caudal em M. atticolus são mais baixas do que muitas outras espécies com caudas brilhantes e coloridas, provavelmente por causa dos hábitos fossoriais e de seu pequeno tamanho corporal. As taxas de autotomia caudal foram mais baixas que esperado ao acaso na parcela com taxas de mortalidade mais baixas, o que sugere um papel mais proeminente da intensidade de predação ao invés da eficiência de predação, e as taxas aumentaram com a idade, sugerindo efeitos cumulativos de tentativas de predação ao longo da ontogenia ou de diferenças específicas da idade na intensidade de predação. Nós também não encontramos diferenças intrasexuais ou qualquer efeito da atividade reprodutiva nas taxas de autotomia caudal. Nossos resultados indicam que os custos energéticos da autotomia caudal são baixos, ou que os animais compensam a perda da cauda com maiores taxas de forrageio. Estas características de $M$. atticolus parecem altamente associadas com seu tamanho corporal pequeno, 
estilo de vida fossorial e de uma curta duração de vida e sugerem que os custos da regeneração da cauda sejam baixos. 


\title{
Blue tales of a blue-tailed lizard: ecological correlates of tail autotomy in Micrablepharus atticolus (Squamata, Gymnophthalmidae) in a Neotropical savannah
}

\author{
H. C. Sousa ${ }^{1}$, B. M. Costa ${ }^{2}$, C. J. S. Morais ${ }^{1}$, D. L. Pantoja ${ }^{1}$, T. A. de Queiroz ${ }^{1}$, C. R. Vieira ${ }^{3}$ \\ \& G. R. Colli ${ }^{1}$ \\ 1 Departamento de Zoologia, Universidade de Brasília, Brasília, DF, Brasil \\ 2 Instituto Federal de Brasília, Gama, DF, Brasil \\ 3 Department of Biology, Utah State University, Logan, UT, USA
}

\section{Keywords}

tail autotomy; predation; defense; energetics; ontogeny; mortality; Cerrado; Neotropics.

\section{Correspondence \\ Guarino R. Colli, Departamento de Zoologia, Universidade de Brasília, 70910-900 Brasília, DF, Brasil. \\ Email: grcolli@unb.br \\ Editor: Mark-Oliver Rödel}

Received 20 April 2015; revised 27 January 2016; accepted 1 February 2016

doi:10.1111/jzo.12335

\begin{abstract}
Tail autotomy and regeneration are perhaps the most dramatic adaptations to enhance survival among lizards. In spite of much work on the subject, the ecological significance of tail autotomy rates in natural populations remains elusive, due to difficulties in controlling several confounding factors and the paucity of accurate demographic data. On the basis of a capture-recapture study, we investigate the ecological determinants of tail autotomy rates in Micrablepharus atticolus, a bluetailed lizard from the South American Cerrado. We tested whether habitat (as a proxy of predation intensity), seasonality (as a proxy of intensity of social interactions), ontogeny and sex affected autotomy rates, and also whether autotomy rates affected body condition. We found that tail autotomy rates in M. atticolus are lower than in many other species with brightly colored tails, likely resulting from a small body size and fossorial habits. Autotomy rates were lower than expected by chance in the plot with lower mortality rates, suggesting a more prominent role of predation intensity instead of predator efficiency, and increased with age, suggesting cumulative effects of predation attempts along the ontogeny or age-specific differences in predation intensity. We also found no intersexual differences or any effect of breeding activity on autotomy rates. Our results indicate that energetic costs of tail autotomy are low, or that animals compensate tail loss with increased foraging rates. These characteristics of $M$. atticolus seem tightly associated with its small body size, fossorial lifestyle and very short life span, and suggest that the costs of tail regeneration should be low.
\end{abstract}

\section{Introduction}

The evolutionary arms race between predators and prey produced a variety of escape tactics in animals (Dawkins \& Krebs, 1979). Among them, tail autotomy and regeneration are perhaps the most dramatic adaptations to enhance survival (reviewed in Arnold, 1984, 1987; Bateman \& Fleming, 2009). When attacked by a predator, many salamanders, most lizards and some snakes may shed a nonessential, wiggling tail that distracts the predator and enables the owner to flee. In lizards, this controlled shedding occurs under a central neural or hormonal control, producing breakage at an intravertebral fracture plane that subdivides or ruptures surrounding tissue and releases the tail (Gilbert, Payne \& Vickaryous, 2013). Following autotomy, most species can produce a new tail supported by a hollow cartilaginous cone and different in many respects from the original tail (Boozalis, LaSalle \& Davis, 2012; Higham, Russell \& Zani, 2013). Tail autotomy can also occur in social contexts, such as during conspecific fights (Arnold, 1987; Bateman \& Fleming, 2009), and is apparently plesiomorphic in Squamata, with multiple independent losses within the clade (Arnold, 1984).

Besides an immediate survival benefit, tail autotomy may also have costs to individual fitness (reviewed in Arnold, 1984, 1987; Bateman \& Fleming, 2009). For instance, tail loss can affect activity and behavior (Cooper \& Wilson, 2008), capacity to distract predators (Cooper \& Smith, 2009), energy balance (Lynn, Borkovic \& Russell, 2013), foraging ability (Wrinn \& Uetz, 2008), growth rates (Iraeta, Salvador \& Diaz, 2012), immunity (Kuo et al., 2013), locomotor performance (Jagnandan, Russell \& Higham, 2014), reproductive success (Lu et al., 2012), social status (Anderson et al., 2012) and survivorship (Salvador \& Veiga, 2005). These costs may be proportional to the amount of tail shed, but this issue is still largely unexplored (Cromie \& Chapple, 2013).

In natural populations, the frequency of autotomized tails is often correlated with predation intensity (Cooper, Perez-Mellado \& 
Vitt, 2004). Nevertheless, this relationship may be modulated by predator efficiency, such that the frequency of autotomized tails is highest when populations are exposed to inefficient predators and vice-versa (Schoener, 1979; Medel et al., 1988; Bateman \& Fleming, 2011), and also by the ease with which individuals shed their tails (Pérez-Mellado, Corti \& LoCascio, 1997; Cooper et al., 2004; Pafilis et al., 2009). In addition, the frequency of autotomized tails in natural populations can be affected by intersexual differences, population density and social interactions (Fox, Rose \& Myers, 1981; Vitt, 1981; Matuschka \& Bannert, 1987; Jennings \& Thompson, 1999); by ontogeny, when the probability of tail autotomy varies with age (Vitt, Congdon \& Dickson, 1977; Kelt, Nabors \& Forister, 2002; Fitch, 2003) and by habitat effects, such that populations inhabiting more exposed habitats show a higher frequency of autotomized tails (Pianka \& Huey, 1978; Tanner \& Perry, 2007; Duckett \& Stow, 2011). In spite of much work on the subject, the ecological significance of autotomy rates in natural populations remains elusive, especially because of the difficulties in controlling several confounding factors, such as age, habitat and sex, and the paucity of accurate demographic data (Schoener, 1979; Bateman \& Fleming, 2009; Higham et al., 2013).

Here, we investigate the ecological determinants of tail autotomy rates in the gymnophthalmid lizard Micrablepharus atticolus (Rodrigues, 1996). This lizard is endemic to, and broadly distributed in, the Brazilian Cerrado, but also occurs in peripheral isolates in southern Amazonia (Santos et al., 2014). Individuals of $M$. atticolus are heliophilous, active during the hottest hours of the day, feed on several groups of arthropods and lay multiple clutches in the breeding season (Vitt, 1991; Vitt \& Caldwell, 1993; Vieira et al., 2000). They are often abundant in open, sandy habitats and have the habit of foraging and burying in the litter, grass and soil (Vitt, 1991; Colli, Bastos \& Araújo, 2002; Gainsbury \& Colli, 2003). Unlike other species that change the tail color during ontogeny (Hawlena et al., 2006), M. atticolus has a conspicuous blue tail whose color does not fade at adulthood. In other species, blue tails are known to effectively divert the attention of predators away from vital parts of the body (Bateman, Fleming \& Rolek, 2014; Ortega, López \& Martín, 2014; Fresnillo, Belliure \& Cuervo, 2015).

We take advantage of a capture-recapture study conducted in a long-term, large-scale experiment to assess the impacts of different burn regimes on the Cerrado biota (Sousa et al., 2015). We test whether habitat (as a proxy of predation intensity), seasonality (as a proxy of intensity of social interactions), ontogeny and sex affect autotomy rates. We predict that autotomy rates are higher (1) in more open habitats, where exposure to predators should be highest; (2) during the reproductive season, when social interactions peak; (3) in older individuals, which have been exposed to predators for longer time; and (4) in males, which are more prone to conspecific aggressive interactions when approaching females. Further, we test the effects of tail autotomy on individual fitness, using body condition as a proxy. We predict that (5) tail loss and the size of the autotomized portion of the tail should result in decreased body condition, due to the loss of energy stores in the tail and reduced foraging ability.

\section{Materials and methods}

\section{Study sites}

We conducted this study in Reserva Ecológica do IBGE $\left(15^{\circ} 56^{\prime} 41^{\prime \prime} \mathrm{S}, 47^{\circ} 53^{\prime} 07^{\prime \prime} \mathrm{W}\right)$, a protected area in Brasília, Distrito Federal, Brazil, at the core of the Cerrado biome (Oliveira \& Marquis, 2002; Ribeiro, 2011). From 1972 to 1990, the reserve was fully protected from fires until 1989, when a long-term experiment was initiated to assess the effects of different burn regimes upon Cerrado animals and plants (Pivello et al., 2010). A large area was divided into 10 ha plots, each subjected to a different combination of the timing (early, modal and late dry season) and frequency (biennial and quadrennial) of prescribed burns. In addition to the costs and difficulties of replication typical of large-scale ecologic studies (Carpenter, 1990; Oksanen, 2001), this experiment could not be replicated because of legal issues associated with burning the vegetation inside protected areas. We selected five plots (Fig. 1) in the cerrado sensu stricto physiognomy: three subjected to prescribed biennial burns (early biennial - EB, middle biennial $\mathrm{MB}$ and late biennial - LB), one subjected to prescribed quadrennial burns (middle quadrennial - Q) and one control plot (C). The last biennial burn occurred in 2008 (i.e. nine burns in each of the $\mathrm{EB}, \mathrm{MB}$ and $\mathrm{LB}$ plots), while the last quadrennial burn occurred in 2007 (i.e. five burns in the Q plot). Because plots were placed in the same physiognomy and shared the same history of burns prior to the onset of the experiment, we assumed that differences between plots through time arose from the effects of prescribed burn regimes.

In Cerrado, frequent burns reduce the recruitment and increase the mortality of woody plants, leading to open physiognomies with decreased abundance and richness of woody plants (Hoffmann, 1999; Moreira, 2000). Further, high fire frequencies stimulate the growth of grasses and a reduction of the leaf litter (Mistry, 1998; Hoffmann \& Moreira, 2002), soil moisture, nutrient pools and nutrient fluxes (Kauffman, Cummings \& Ward, 1994; Nardoto et al., 2006; Valenti, Cianciaruso \& Batalha, 2008). Conversely, fire suppression leads to canopy closing, due to increased abundance and richness of woody plants, and potentially toward the forested 'cerradão' physiognomy. Still, fire intensity is highest during the late dry season in Cerrado, because most of the combustible fuel is dry, relative air humidity is at its lowest and wind speed is at its highest (Mistry, 1998; Ramos, dos Santos \& Fortes, 2009). Therefore, fire severity and habitat openness in experimental plots increased in this order: $\mathrm{C} \rightarrow \mathrm{Q} \rightarrow \mathrm{EB} \rightarrow \mathrm{MB} \rightarrow \mathrm{LB}$ (Fig. 2). We assumed that lizards inhabiting plots with increased habitat openness and reduced leaf litter are more exposed to predators, and as a consequence, should exhibit higher frequency of tail autotomy (Pianka \& Huey, 1978; Tanner \& Perry, 2007).

\section{Captures and recaptures}

We monitored the populations of $M$. atticolus in the study plots from October 2010 to November 2014 (details in Sousa et al., 2015). In each plot, we placed 10 arrays of pitfall traps 

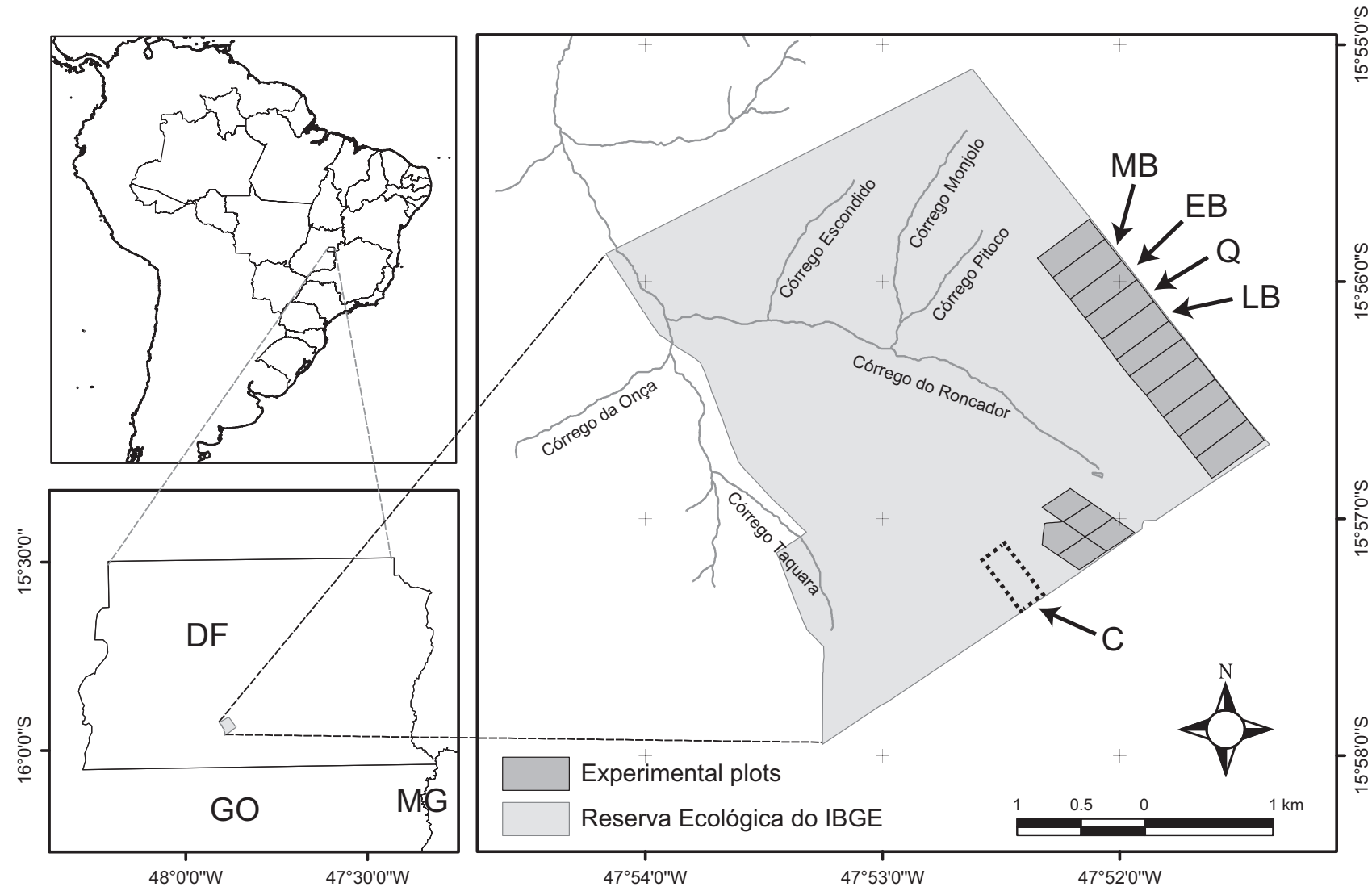

Figure 1 Map indicating study site in Reserva Ecológica do IBGE, Brasília, Distrito Federal, Brazil and the location of experimental plots. DF, Distrito Federal; GO, Goiás; MG, Minas Gerais; C, control; EB, early biennial; LB, late biennial; MB, middle biennial; $Q$, quadrennial.

with drift fences (Fig. 2). Each array consisted of four 301 buckets buried into the ground and configuring a Y-shape format. One bucket was placed at the center and the other three buckets at the tips, arranged in $120^{\circ}$ angles. The buckets at the tips were connected with the central bucket by $50-\mathrm{cm}$ high metal drift fences, $6 \mathrm{~m}$ away from the central bucket. We opened the traps during six consecutive days every month, and checked daily during this period. We recorded the following data of each captured lizard: snout-vent length (SVL), tail length and length of regenerated portion of tail (if any), with a ruler (1-mm precision); body mass, with a spring scale $(0.1 \mathrm{~g}$ precision); and sex. If a lizard's tail was broken but had not yet regenerated, then we regarded the length of the regenerated portion of the tail as zero. To determine the sex of each individual, we first assessed the presence of eggs in gravid females, then the presence of hemipenis by eversion; adult individuals ( $S V L \geq 35 \mathrm{~mm}$, Sousa et al., 2015) without hemipenis or eggs were regarded as non-gravid females; individuals with SVL $<35 \mathrm{~mm}$ were regarded as juveniles, and if recaptured as adults, sexed later. In the analyses involving sex, we only used those individuals that could be sexed. Next, each lizard was individually marked by toe-clipping and immediately released at the site of capture. Toe-clipping is extensively used for permanently marking lizards and most studies to date have found no effects on locomotor performance, stress level or survival, except in species that rely on modified subdigital lamellae for clinging (Borges-Landaez \& Shine, 2003; Jones \& Bell, 2010; Hoehn, Henle \& Gruber, 2015). We did not clip more than two toes per limb for each lizard. During the entire study period there were no recaptures indicative of movements among plots.

\section{Statistical analyses}

To investigate the relationship between habitat openness and predation intensity, we used the capture history of each individual of $M$. atticolus to assess the effects of fire regimen on vital demographic rates, with package BaSTA (Colchero, Jones \& Rebke, 2012). In demographic analysis, the capture history of each individual is a sequence of presences-absences along the sampling occasions, represented as a binary variable (1-0). Here, we assumed that predation intensity and mortality rate are positively correlated. Mortality in natural populations of lizards can result from predation, diseases, starvation, anthropogenic disturbances and natural catastrophes. Among them, predation is often considered the leading agent of mortality (e.g. Schoener \& Spiller, 1996; Campbell et al., 2012; Wolf et al., 2013). We have no data on the role of diseases, but 

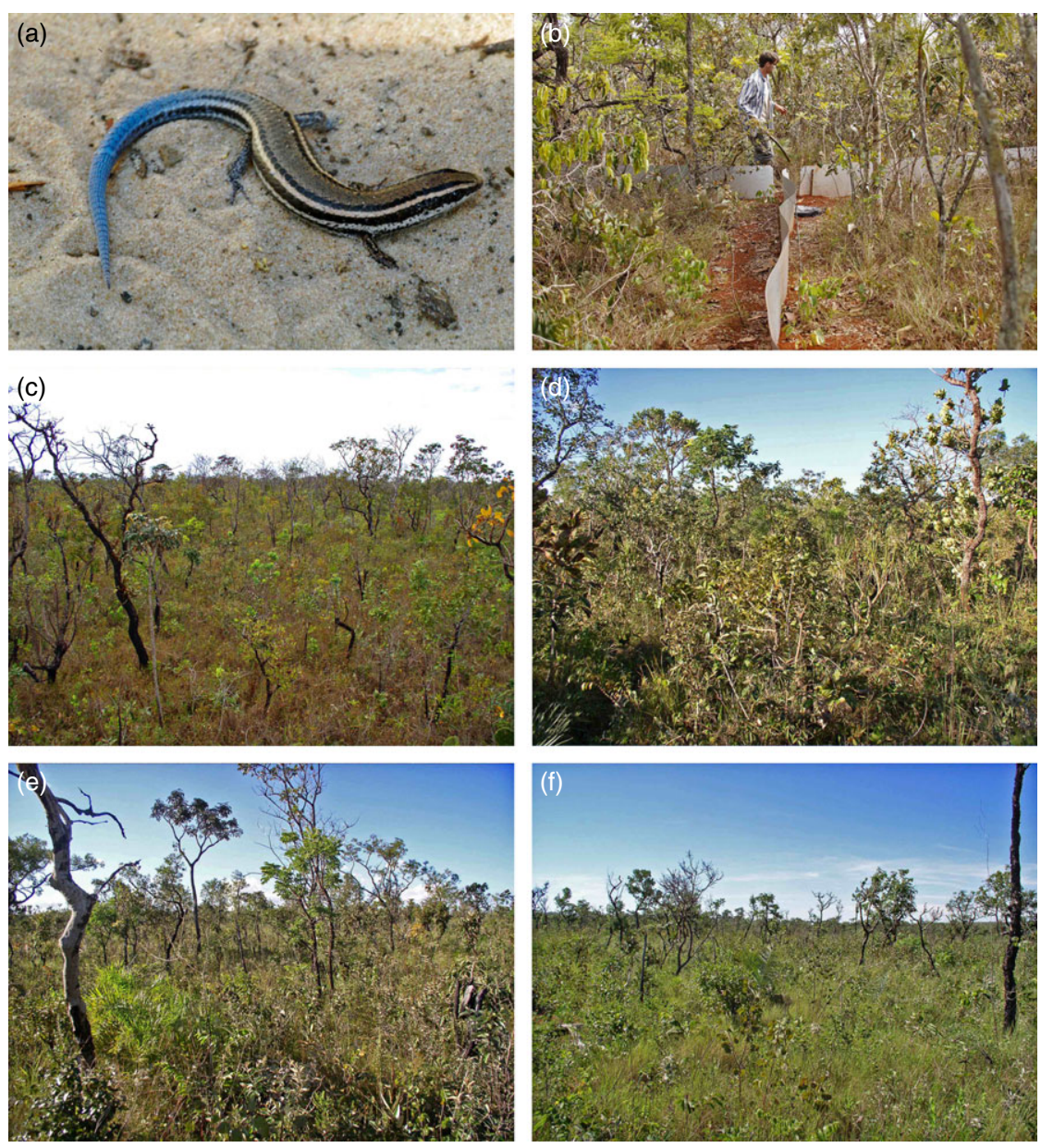

Figure 2 Micrablepharus atticolus and experimental plots submitted to different fire regimes in Reserva Ecológica do IBGE, Brasília, Distrito Federal, Brazil. (a) individual of M. atticolus with broken and regenerated tail (OGRC); (b) control plot, depicting array of pitfall traps (OCRV); (c) quadrennial plot (CDLP); (d) early biennial plot (ODLP); (e) middle biennial plot (CDLP); (f) late biennial plot (ODLP).

food supply seems to be abundant and fires have negligible direct effects on lizard populations in the study site (Colli, Peres \& Zatz, 1997; Costa et al., 2013). BaSTA uses Bayesian analyses coupled with Markov chain Monte Carlo (MCMC) methods to model age-specific survival from capture-recapture data in the presence of covariates (Colchero \& Clark, 2012). The following parameters were used in this analysis: Gompertz mortality function (model $=$ 'GO') with a Makeham shape $($ shape $=$ 'Makeham'), $10 \quad$ MCMC simulations $\quad(n s i m=10)$ each with $10^{5}$ iterations $($ niter $=100000$ ), sampled at each 100 iterations (thinning $=100$ ) and discarding the first $10^{4}$ iterations as burnin (burnin $=10001$ ). Multiple runs were performed in parallel $($ parallel $=\mathrm{T}$, ncpus $=4)$, using package snowfall (Knaus, 2013).

To assess the effects of habitat openness, seasonality, sex and ontogeny upon the occurrence of tail autotomy, we used a generalized linear mixed model (GLMM) with a binomial error distribution and a logit link function (Crawley, 2013), implemented in package lme4 (Bates et al., 2014). We first created a full model in which the condition of the tail (broken vs. intact) of each captured individual was the response variable; SVL, sex, habitat (fire regime) and insolation were fixed effects; and year and individual (identity) were random effects, to account for recaptures. Insolation was used as a variable describing climate seasonality in Cerrado, because a previous study that investigated the demography of $M$. atticolus found that, among several climate variables, insolation was the most important predictor of temporal variation in SVL and the only simultaneous predictor of survival, recapture and recruitment (Sousa et al., 2015). Next, we assessed the adequacy of the full model by comparison with a null, intercept-only model (including the random effects) via the Pearson $\chi^{2}$ statistic. To determine predictor importance, we used a manual forward selection approach by adding variables to the null model and assessing model improvement with a significance $\left(\chi^{2}\right)$ test of the reduction in scaled deviance (Crawley, 2013). Further, we used an information-theoretic approach by ranking all possible models according to their Akaike information criterion cor- 
rected for small samples $\left(\mathrm{AIC}_{c}\right)$ and calculating model-averaged coefficients, with package MuMIn (Bartón, 2014). In this last approach, predictor importance is defined as the sum of the Akaike weights $\left(\mathrm{wAIC}_{c}\right)$ for all models containing a given predictor (Burnham \& Anderson, 2002).

To investigate the possible costs of tail autotomy for individual fitness, we assessed the effects of tail breakage upon body condition. We defined body condition as the scaled mass index (SMI) of Peig \& Green (2009), computed as:

$$
\widehat{\mathrm{M}}_{i}=\mathrm{M}_{i}\left(\frac{\mathrm{L}_{0}}{\mathrm{~L}_{i}}\right)^{b_{\mathrm{SMA}}}
$$

where $\mathrm{M}_{i}$ and $\mathrm{L}_{i}$ are the body mass and the SVL of individual $i$, respectively; $\mathrm{L}_{0}$ is the mean $\mathrm{SVL}$ in the study population; and $b_{\mathrm{SMA}}$ is a scaling factor. We computed $b_{\mathrm{SMA}}$ from a standardized major axis (SMA) regression (Warton et al., 2006) of $\ln (M+1)$ on $\ln (\mathrm{L})$, using package lmodel2 (Legendre, 2014). Unlike most conventional methods of estimating body condition, the SMI can successfully account for the varying relationship between M and L during ontogeny (Peig \& Green, 2010) and is a good predictor of variations in fat and protein reserves in diverse vertebrate groups (Peig \& Green, 2009). Next, we built a GLMM in which SMI was the response variable, tail condition (broken vs. intact) was the fixed effect and year and individual (identity) were random effects. We assessed the adequacy of the model as indicated above. We also tested the significance of the relationship between SMI and the length of the regenerated portion of the tail, and between SMI and the proportion of the regenerated portion of the tail using a standard least-squares linear model. We conducted statistical analyses with software R (R Core Team 2014), using a significance level of $5 \%$ when testing hypotheses.

\section{Results}

Along 4 years, we marked 190 individuals of M. atticolus, representing 253 captures and recaptures in the five monitored plots. On average, each lizard was captured on 1.24 occasions and $32.63 \%$ of the individuals had autotomized tails. Pooling all captures, mean SVL was $35.67 \pm 5.75(14-48, n=253)$ and mean tail length was $44.80 \pm 12.31(8-74, n=253)$. Considering only individuals with intact tails, mean SVL was $34.47 \pm 6.33(14-45, n=156)$ and mean tail length was $49.30 \pm 10.92 \quad(16-74, \quad n=156)$. Tail length represented $1.42 \pm 0.17(1.04-2.11)$ times the SVL. The age-specific survival and mortality models estimated by BaSTA indicated that mortality increased with age; further, it was highest in the LB and $\mathrm{C}$ plots, and lowest in the MB plot (Fig. 3).

The full GLMM relating tail autotomy to SVL, habitat, insolation and sex was highly significant $\left(\chi_{[8]}^{2}=28.22, P<0.001\right)$. The model averaging analysis, model-averaged coefficients and relative variable importance clearly indicated SVL and habitat are the best predictors of tail autotomy (Table 1). The probability of tail autotomy increased significantly with SVL $\left(\chi_{[1]}^{2}=11.45, P<0.001\right.$, Fig. 4) and was significantly lower in the EB plot $\left(\chi_{[4]}^{2}=10.79, P=0.029\right.$, Fig. 5).

The GLMM relating SMI to tail autotomy was not significant $\left(\chi_{[1]}^{2}=0.12, P=0.734\right)$. There was no relationship between SMI and either the length $\left(F_{1,211}=0.074, P=0.786\right)$ or the proportion of the regenerated portion of the tail $\left(F_{1,211}=0.335, P=0.564\right)$.

\section{Discussion}

Inferences drawn from population-level studies of tail autotomy are often limited by the lack of information on the predators
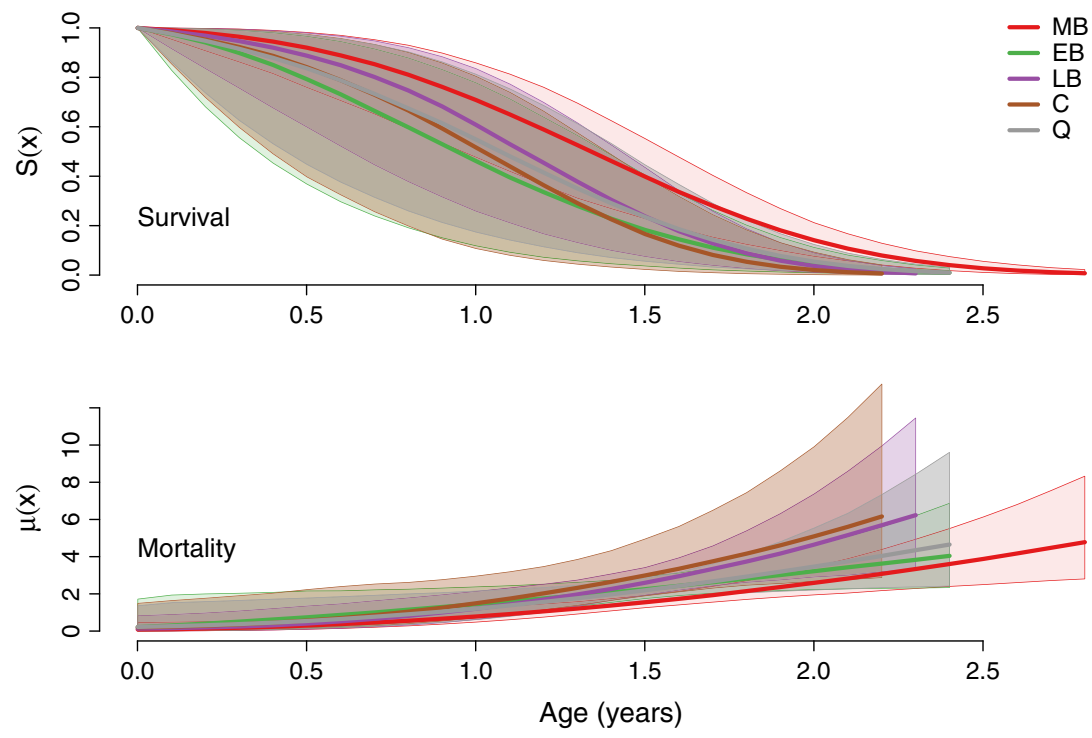

Figure 3 Predicted survival probability and mortality rate of Micrablepharus atticolus in experimental plots submitted to different fire regimes at Reserva Ecológica do IBGE, Brasília, Distrito Federal, Brazil: late biennial (LB), middle biennial (MB), early biennial (EB), quadrennial (Q) and control (C). The width of the survival probability and mortality rate polygons corresponds to the $95 \%$ credible intervals. Mortality rates were higher in the $\mathrm{C}$ and LB plots. 
Table 1 Model selection, model-averaged coefficients and relative variable importance of generalized linear mixed-effects models (GLMMs), relating the incidence of tail autotomy in Micrablepharus atticolus to insolation, snout-vent length (SVL), sex and fire regime, in Reserva Ecológica do IBGE, Brasília, Distrito Federal, Brazil, from October 2010 to November 2014

\begin{tabular}{|c|c|c|c|c|}
\hline Model & d.f. & $\mathrm{AlC}_{c}$ & $\Delta \mathrm{AlC}_{c}$ & wAIC $_{c}$ \\
\hline$\overline{\text { Regime + SVL }}$ & 8 & 259.15 & 0.00 & 0.56 \\
\hline Regime + SVL + insolation & 9 & 260.83 & 1.68 & 0.24 \\
\hline Regime + SVL + sex & 10 & 262.77 & 3.62 & 0.09 \\
\hline Regime + SVL + insolation + sex & 11 & 264.45 & 5.30 & 0.04 \\
\hline SVL & 4 & 266.15 & 7.00 & 0.02 \\
\hline Regime + sex & 9 & 266.46 & 7.31 & 0.01 \\
\hline SVL + insolation & 5 & 267.20 & 8.05 & 0.01 \\
\hline Regime + insolation + sex & 10 & 267.65 & 8.50 & 0.01 \\
\hline Regime + insolation & 8 & 268.43 & 9.28 & 0.01 \\
\hline SVL + sex & 6 & 268.78 & 9.63 & 0.00 \\
\hline SVL + insolation + sex & 7 & 270.40 & 11.25 & 0.00 \\
\hline Insolation & 4 & 271.28 & 12.13 & 0.00 \\
\hline Sex & 5 & 271.34 & 12.19 & 0.00 \\
\hline Insolation + sex & 6 & 271.65 & 12.50 & 0.00 \\
\hline Regime & 7 & 273.15 & 14.00 & 0.00 \\
\hline Intercept-only & 3 & 275.53 & 16.38 & 0.00 \\
\hline Model-averaged coefficients & Estimate & SE & $z$ & $P$ \\
\hline (Intercept) & 0.000 & 0.000 & - & - \\
\hline Regime (EB) & -3.573 & 2.105 & 1.689 & 0.091 \\
\hline Regime (LB) & 0.005 & 0.934 & 0.005 & 0.996 \\
\hline Regime (C) & -0.999 & 1.191 & 0.834 & 0.404 \\
\hline Regime (Q) & -0.887 & 1.237 & 0.713 & 0.476 \\
\hline SVL & 3.234 & 1.767 & 1.822 & 0.069 \\
\hline Insolation & 0.195 & 0.556 & 0.350 & 0.727 \\
\hline Sex (Juvenile) & -0.102 & 0.596 & 0.171 & 0.864 \\
\hline Sex (Male) & 0.093 & 0.397 & 0.232 & 0.817 \\
\hline Relative variable importance & SVL & Regime & Insolation & Sex \\
\hline Importance & 0.97 & .96 & 0.31 & 0.16 \\
\hline
\end{tabular}

Juvenile lizards could not be sexed and formed a third 'sex'.

d.f., degrees of freedom; $\mathrm{AlC}_{c}$, Akaike information criterion adjusted for small samples; $\triangle \mathrm{AIC}_{c}$, difference in $\mathrm{AlC}_{c}$ between candidate and best model (minimum $\mathrm{AlC}_{c}$ ); $\mathrm{wAIC}_{c}$, Akaike weight; representing normalized likelihood or weight of evidence in favor of candidate model; EB, early biennial fire regime; LB, late biennial fire regime; $C$, control (fire suppression); $\mathrm{Q}$, quadrennial fire regime.

or the type of interaction that happens between predator and prey: low autotomy rates may mean high predator efficiency, rather than low susceptibility to predator attacks. To attenuate some of these limitations, we estimated vital rates of $M$. atticolus populations based on a long-term capture-recapture study. Rates of tail autotomy in M. atticolus (33\%) are similar to those reported for other gymnophthalmids, but are lower than many other species that lack a colored and conspicuous tail (e.g. Zani, 1996; Bateman \& Fleming, 2009; Fleming, Valentine \& Bateman, 2013). Nevertheless, lizards with conspicuously colored tails often show higher frequencies of tail autotomy in comparison with our results (e.g. Vitt et al., 1977;

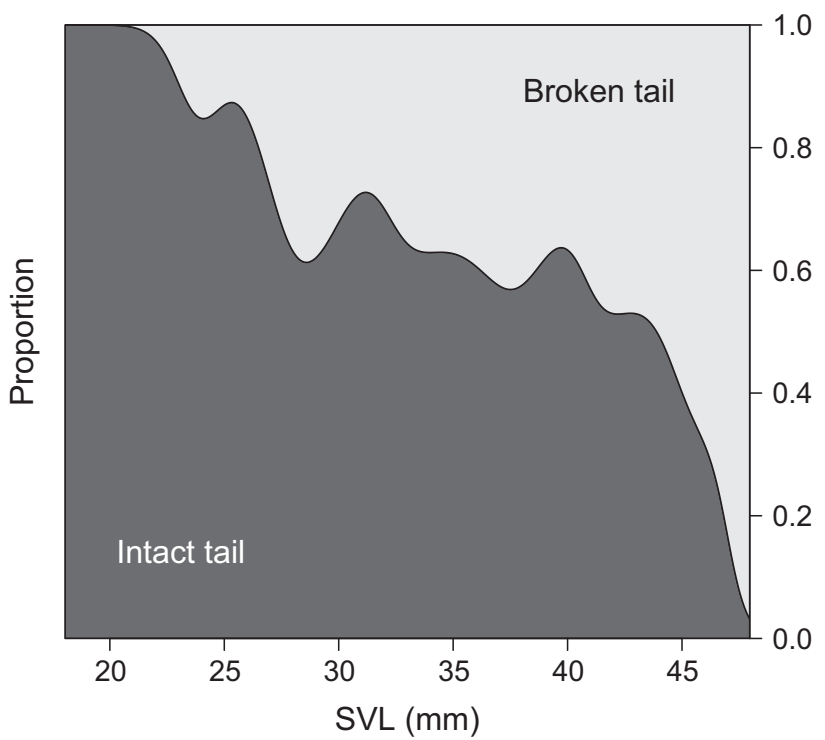

Figure 4 Changes in the conditional distribution of tail state (intact vs. broken) according to snout-vent length (SVL) in the lizard Micrablepharus atticolus at Reserva Ecológica do IBGE, Brasília, Distrito Federal, Brazil. A smoothing approach via kernel density estimates was used to derive conditional probabilities. The conditional plot indicates that the probability of tail breakage increases with SVL.

Vitt \& Cooper, 1986; Fitch, 2003). Conspicuously, colored tails are known to divert the attention of predators, with red and blue being the most effective colors. This strategy can be particularly important for animals that live in open habitats, which are probably more susceptible to detection by visually oriented predators. However, due to its small body size and fossorial habits, M. atticolus may be less susceptible to predator attacks, and consequently, show lower autotomy rates (Fleming et al., 2013).

Mortality rates of $M$. atticolus were highest at the extremes of the habitat openness gradient (LB and C plots). Although direct observations of predation events are scanty (but see Maffei, Ubaid \& Jim, 2010), mortality rates indicate that predation is highest in more open plots (LB) due to increased exposure to predators, and in more closed plots (C) due to higher density of predators. Small lizards are preyed upon by a variety of arthropods, mammals, birds and other reptiles, especially snakes (Jaksic et al., 1982; Bauer, 1990; Pike et al., 2010). Overall, the abundance and species richness of birds (Tubelis \& Cavalcanti, 2001; Macedo, 2002), mammals (Carmignotto, Bezerra \& Rodrigues, 2014) and reptiles (Nogueira, Colli \& Martins, 2009) is highest in denser Cerrado physiognomies. More specifically, the abundance of cursorial spiders, which feed on M. atticolus (Maffei et al., 2010), is highest in the control (C) plot (Freire \& Motta, 2011). Contrary to our expectations, rates of tail autotomy were not significantly higher in the LB plot and neither in the $\mathrm{C}$ plot. However, autotomy rates were smaller than expected by chance in the EB plot, where mortality rates were among the lowest. These 


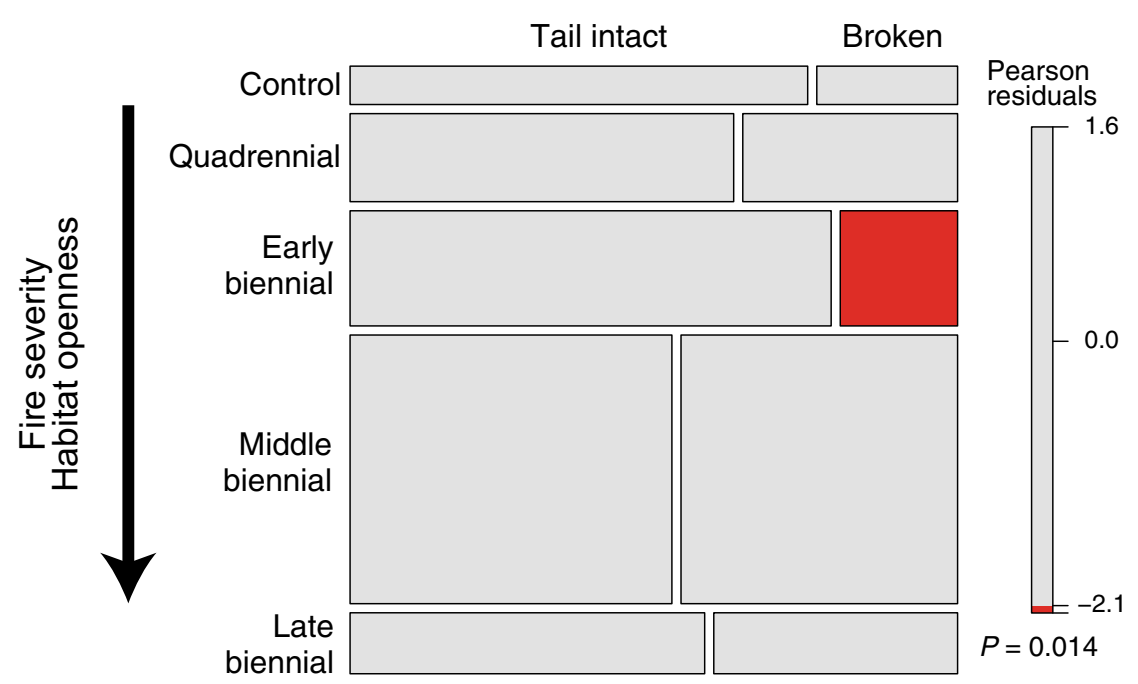

Figure 5 Extended mosaic plot with residual-based shading depicting the proportion of individuals of the lizard Micrablepharus atticolus with broken or intact tails, in five experimental plots submitted to different fire regimes at Reserva Ecológica do IBGE, Brasília, Distrito Federal, Brazil. The dark red cell indicates that in the plot submitted to biennial prescribed fires early in the dry season, the number of lizards with broken tails was smaller than expected by chance. The width of each cell is proportional to the number of captured lizards.

mixed findings are not conclusive, but suggest that autotomy rates in $M$. atticolus reflect predation intensity, instead of predator efficiency. If autotomy rates indicated predator efficiency, we would expect highest mortality in the EB plot.

$M$. atticolus has a well-defined reproductive cycle, with reproductive activity concentrated in the dry season, and its populations undergo an almost complete annual turnover (Sousa et al., 2015). Therefore, we predicted high rates of tail autotomy during the peak of breeding activity, as a result of conspecific aggressive interactions, and also in males, which are more prone to fights when approaching females (Bateman \& Fleming, 2009). However, reproductive seasonality expressed as hours of insolation had low predictive power for autotomy rates. Further, the lack of intersexual differences in autotomy rates supports the view that conspecific aggressive interactions play a minor role, if any, in autotomy rates of M. atticolus.

We found that rates of tail autotomy correlate with SVL, and consequently, with age in $M$. atticolus. This is in line with the view that older individuals have been exposed to predators for a longer time; thus, they are more likely to have experienced autotomy events (Bateman \& Fleming, 2009). Nevertheless, ontogenetic shifts in autotomy rates may as well result from age-specific differences in predation intensity or readiness to autotomize the tail (Vitt et al., 1977; Cooper et al., 2004; Pafilis et al., 2009). In M. atticolus, mortality rates increase with age and most individuals die after their first reproduction. Larger, older individuals may become more susceptible to predation, and thus to tail autotomy, with the increased activity associated with their single mating season. In fact, mean SVL of captured individuals, probability of capture and reproductive activity all peak in the dry season (Sousa et al., 2015). Future works should address the existence of ontogenetic variation in the ease of tail autotomy.
There was no association between tail autotomy and body condition in $M$. atticolus. We expected that body condition would be reduced following tail autotomy as a consequence of the energetic costs of tail regeneration and the loss of fat stored in the tail (Lynn et al., 2013), or of reduced foraging and prey capture abilities (Martin \& Avery, 1997; Cooper, 2003). There is no information on the fat content of $M$. atticolus tails (or gymnophthalmids, in general) and this is an issue that warrants further investigation. Nevertheless, our results suggest that either the energetic costs of autotomy are low, or that animals compensate tail loss with increased foraging rates, as documented in other species (Dial \& Fitzpatrick, 1981).

Reduced foraging efficiency may result from decreased locomotor performance or increased vulnerability to predation following tail autotomy. Gymnophthalmid lizards are characterized by body elongation and limb reduction (Wiens, Brandley \& Reeder, 2006), which may be extreme in some forms, such as Bachia, Calyptommatus, Notobachia and Scriptosaura. With body elongation and limb reduction, there is increased reliance on the vertebral axis as the main driver of locomotion (Renous, Hofling \& Gasc, 1998). In such species, tail autotomy may not imply a significant locomotor cost, because the whole body is used for serpentine movement or burrowing (Arnold, 1984; Fleming et al., 2013), unless a very large portion of the tail is lost (Lin \& Ji, 2005). Nevertheless, Micrablepharus lizards rely more on quadrupedal locomotion (Renous, Hofling \& Gasc, 1999), as it happens with the close relative Vanzosaura (Höfling \& Renous, 2004; Renous, Hofling \& Bels, 2008; Recoder et al., 2014). Taking the above and a fossorial lifestyle, tail autotomy apparently does not impair locomotion or affect vulnerability to predation in M. atticolus.

In conclusion, our results indicate that despite possessing a long, brightly colored blue tail, rates of tail autotomy in 
M. atticolus are comparatively low. Further, they support the role of habitat and ontogeny, but not the effects of sex or conspecific aggression upon autotomy rates in natural populations of $M$. atticolus. Finally, our results indicate no significant effects of tail autotomy on body condition. These characteristics of the species seem tightly associated with certain aspects of its ecology, most importantly the small body size, fossorial lifestyle and very short life span, and suggest that the costs of tail regeneration should be low, what could be addressed in future studies.

\section{Acknowledgements}

We thank the staff of Reserva Ecológica do IBGE for being extremely supportive and all field assistants that helped in this long-term study. We also thank Coordenação de Apoio à Formação de Pessoal de Nível Superior - CAPES, Conselho Nacional do Desenvolvimento Científico e Tecnológico $\mathrm{CNPq}$ and Fundação de Apoio à Pesquisa do Distrito Federal - FAPDF for financial support.

\section{References}

Anderson, M.L., Cavalieri, C.N., Rodríguez-Romero, F. \& Fox, S.F. (2012). The differential effect of tail autotomy on sprint performance between the sexes in the lizard Uta stansburiana. J. Herpetol. 46, 648-652.

Arnold, E.N. (1984). Evolutionary aspects of tail shedding in lizards and their relatives. J. Nat. Hist. 18, 127-169.

Arnold, E.N. (1987). Caudal autotomy as a defense. In Biology of the Reptilia. Volume 16. Ecology B. Defense And Life History: 235-273. Gans, C. \& Huey, R.B. (Eds). New York: Alan R. Liss, Inc.

Bartón, K. (2014). MuMIn: Multi-model inference: R package version 1.10.5. Available at: http://CRAN.R-project.org/ package=MuMIn

Bateman, P.W. \& Fleming, P.A. (2009). To cut a long tail short: a review of lizard caudal autotomy studies carried out over the last 20 years. J. Zool. 277, 1-14.

Bateman, P.W. \& Fleming, P.A. (2011). Frequency of tail loss reflects variation in predation levels, predator efficiency, and the behaviour of three. Biol. J. Linn. Soc. 103, 648-656.

Bateman, P.W., Fleming, P.A. \& Rolek, B. (2014). Bite me: blue tails as a 'risky-decoy' defense tactic for lizards. Curr. Zool. 60, 333-337.

Bates, D., Maechler, M., Bolker, B. \& Walker, S. (2014). lme4: Linear mixed-effects models using Eigen and S4, R package version 1.1-7. Available at: http://CRAN.R-project.org/ package $=1 m e 4$.

Bauer, A.M. (1990). Gekkonid lizards as prey of invertebrates and predators of vertebrates. Herpetol. Rev. 21, 83-87.

Boozalis, T.S., LaSalle, L.T. \& Davis, J.R. (2012). Morphological and biochemical analyses of original and regenerated lizard tails reveal variation in protein and lipid composition. Comp. Biochem. Phys. A-Mol. Integr. Physiol. 161, 77-82.
Borges-Landaez, P.A. \& Shine, R. (2003). Influence of toeclipping on running speed in Eulamprus quoyii, an Australian scincid lizard. J. Herpetol. 37, 592-595.

Burnham, K.P. \& Anderson, D.R. (2002). Model Selection and Multi-Model Inference. 2nd edn. New York: Springer-Verlag.

Campbell, E.W., Adams, A.A.Y., Converse, S.J., Fritts, T.H. \& Rodda, G.H. (2012). Do predators control prey species abundance? An experimental test with brown treesnakes on Guam. Ecology 93, 1194-1203.

Carmignotto, A.P., Bezerra, A.M.R. \& Rodrigues, F.H.G. (2014). Nonvolant small mammals from a southwestern area of Brazilian Cerrado: diversity, habitat use, seasonality, and biogeography. Therya 5, 535-558.

Carpenter, S.R. (1990). Large-scale perturbations: opportunities for innovation. Ecology 71, 2038-2043.

Colchero, F. \& Clark, J.S. (2012). Bayesian inference on agespecific survival for censored and truncated data. J. Anim. Ecol. 81, 139-149.

Colchero, F., Jones, O.R. \& Rebke, M. (2012). BaSTA: an R package for Bayesian estimation of age-specific survival from incomplete mark-recapture/recovery data with covariates. Methods Ecol. Evol. 3, 466-470.

Colli, G.R., Peres, A.K. \& Zatz, M.G. (1997). Foraging mode and reproductive seasonality in tropical lizards. J. Herpetol. 31, 490-499.

Colli, G.R., Bastos, R.P. \& Araújo, A.F.B. (2002). The character and dynamics of the Cerrado herpetofauna. In The Cerrados of Brazil: ecology and Natural History of a Neotropical Savanna: 223-241. Oliveira, P.S. \& Marquis, R.J. (Eds). New York: Columbia University Press.

Cooper, W.E. (2003). Shifted balance of risk and cost after autotomy affects use of cover, escape, activity, and foraging in the keeled earless lizard (Holbrookia propinqua). Behav. Ecol. Sociobiol. 54, 179-187.

Cooper, W.E. \& Smith, C.S. (2009). Costs and economy of autotomy for tail movement and running speed in the skink Trachylepis maculilabris. Can. J. Zool. 87, 400-406.

Cooper, W.E. \& Wilson, D.S. (2008). How to stay alive after losing your tail. Behaviour 145, 1085-1099.

Cooper, W.E., Perez-Mellado, V. \& Vitt, L.J. (2004). Ease and effectiveness of costly autotomy vary with predation intensity among lizard populations. J. Zool. 262, 243-255.

Costa, B.M., Pantoja, D.L., Vianna, M.C.M. \& Colli, G.R. (2013). Direct and short-term effects of fire on lizard assemblages from a Neotropical savanna hotspot. J. Herpetol. 47, 502-510.

Crawley, M.J. (2013). The R Book. Chichester: John Wiley \& Sons Ltd.

Cromie, G.L. \& Chapple, D.G. (2013). Is partial tail loss the key to a complete understanding of caudal autotomy? Austral Ecol. 38, 452-455.

Dawkins, R. \& Krebs, J.R. (1979). Arms races between and within species. Proc. R. Soc. Ser. B-Bio. 205, 489-511.

Dial, B.E. \& Fitzpatrick, L.C. (1981). The energetic costs of tail autotomy to reproduction in the lizard Coleonyx brevis (Sauria: Gekkonidae). Oecologia 51, 310-317. 
Duckett, P.E. \& Stow, A.J. (2011). Levels of dispersal and tail loss in an Australian gecko (Gehyra variegata) are associated with differences in forest structure. Aust. J. Zool. 59, 170.

Fitch, H.S. (2003). A comparative study of loss and regeneration of lizard tails. J. Herpetol. 37, 395-399.

Fleming, P.A., Valentine, L.E. \& Bateman, P.W. (2013). Telling tails: selective pressures acting on investment in lizard tails. Physiol. Biochem. Zool. 86, 645-658.

Fox, S.F., Rose, E. \& Myers, R. (1981). Dominance and the acquisition of superior home ranges in the lizard Uta stansburiana. Ecology 62, 888-893.

Freire, G.D. \& Motta, P.C. (2011). Effects of experimental fire regimes on the abundance and diversity of cursorial arachnids of Brazilian savannah (Cerrado biome). J. Arachnol. 39, 263272.

Fresnillo, B., Belliure, J. \& Cuervo, J.J. (2015). Red tails are effective decoys for avian predators. Evol. Ecol. 29, 123-135.

Gainsbury, A.M. \& Colli, G.R. (2003). Lizard assemblages from natural cerrado enclaves in southwestern Amazonia: the role of stochastic extinctions and isolation. Biotropica 35, 503-519.

Gilbert, E.A.B., Payne, S.L. \& Vickaryous, M.K. (2013). The anatomy and histology of caudal autotomy and regeneration in lizards. Physiol. Biochem. Zool. 86, 631-644.

Hawlena, D., Boochnik, R., Abramsky, Z. \& Bouskila, A. (2006). Blue tail and striped body: why do lizards change their infant costume when growing up? Behav. Ecol. 17, 889896.

Higham, T.E., Russell, A.P. \& Zani, P.A. (2013). Integrative biology of tail autotomy in lizards. Physiol. Biochem. Zool. 86, 603-610.

Hoehn, M., Henle, K. \& Gruber, B. (2015). The effect of toeclipping on the survival of gecko and skink species. Herpetol. Conserv. Biol. 10, 242-254.

Hoffmann, W.A. (1999). Fire and population dynamics of woody plants in a Neotropical savanna: matrix model projections. Ecology 80, 1354-1369.

Hoffmann, W.A. \& Moreira, A.G. (2002). The role of fire in population dynamics of woody plants. In The Cerrados of Brasil: ecology and Natural History of a Neotropical Savanna: 159-177. Oliveira, P.S. \& Marquis, R.J. (Eds). New York: Columbia University Press.

Höfling, E. \& Renous, S. (2004). High frequency of pauses during intermittent locomotion of small South American gymnophthalmid lizards (Squamata, Gymnophthalmidae). Phyllomedusa 3, 83-94.

Iraeta, P., Salvador, A. \& Diaz, J.A. (2012). Effects of caudal autotomy on postnatal growth rates of hatchling Psammodromus algirus. J. Herpetol. 46, 342-345.

Jagnandan, K., Russell, A.P. \& Higham, T.E. (2014). Tail autotomy and subsequent regeneration alter the mechanics of locomotion in lizards. J. Exp. Biol. 217, 3891-3897.

Jaksic, F.M., Greene, H.W., Schwenk, K. \& Seib, R.L. (1982). Predation upon reptiles in Mediterranean habitats of Chile, Spain and California: a comparative analysis. Oecologia 53, $152-159$.
Jennings, W.B. \& Thompson, G.G. (1999). Territorial behavior in the Australian scincid lizard Ctenotus fallens. Herpetologica 55, 352-361.

Jones, C. \& Bell, T. (2010). Relative effects of toe-clipping and pen-marking on short-term recapture probability of McCann's skinks (Oligosoma maccanni). Herpetol. J. 20, 237-241.

Kauffman, J.B., Cummings, D.L. \& Ward, D.E. (1994). Relationships of fire, biomass and nutrient dynamics along a vegetation gradient in the Brazilian Cerrado. J. Ecol. 82, 519531.

Kelt, D.A., Nabors, L.K. \& Forister, M.L. (2002). Size-specific differences in tail loss and escape behavior in Liolaemus nigromaculatus. J. Herpetol. 36, 322-325.

Knaus, J. (2013). snowfall: Easier cluster computing (based on snow), R package version 1.84-6. Available at: http:// CRAN.R-project.org/package=snowfall.

Kuo, C.C., Yao, C.J., Lin, T.E., Liu, H.C., Hsu, Y.C., Hsieh, M.K. \& Huang, W.S. (2013). Tail loss compromises immunity in the many-lined skink, Eutropis multifasciata.

Naturwissenschaften 100, 379-384.

Legendre, P. (2014). lmodel2: Model II Regression, R package version 1.7-2. Available at: http://CRAN.R-project.org/ package $=$ lmodel 2 .

Lin, Z.H. \& Ji, X. (2005). Partial tail loss has no severe effects on energy stores and locomotor performance in a lacertid lizard, Takydromus septentrionalis. J. Comp. Physiol. B. 175, 567-573.

Lu, H., Gao, J., Ma, X., Lin, Z. \& Ji, X. (2012). Tail loss affects fecundity but not offspring traits in the Chinese skink Eumeces chinensis. Curr. Zool. 58, 228-235.

Lynn, S.E., Borkovic, B.P. \& Russell, A.P. (2013). Relative apportioning of resources to the body and regenerating tail in juvenile leopard geckos (Eublepharis macularius) maintained on different dietary rations. Physiol. Biochem. Zool. 86, 659-668.

Macedo, R.H.F. (2002). The avifauna: ecology, biogeography, and behavior. In The Cerrados of Brazil: 242-265. Oliveira, P.S. \& Marquis, R.J. (Eds). New York: Columbia University Press.

Maffei, F., Ubaid, F.K. \& Jim, J. (2010). Predation of herps by spiders (Araneae) in the Brazilian Cerrado. Herpetol. Notes 3, 167-170.

Martin, J. \& Avery, R.A. (1997). Tail loss affects prey capture 'decisions' in the lizard Psammodromus algirus. J. Herpetol. 31, 292-295.

Matuschka, F.-R. \& Bannert, B. (1987). Cannibalism and autotomy as predator-prey relationship for monoxenous Sarcosporidia. Parasitol. Res. 74, 88-93.

Medel, R.G., Jimenez, J.E., Fox, S.F. \& Jaksic, F.M. (1988). Experimental evidence that high population frequencies of lizard tail autotomy indicate inefficient predation. Oikos 53, 321-324.

Mistry, J. (1998). Fire in the Cerrado (savannas) of Brazil: an ecological review. Prog. Phys. Geog. 22, 425-448.

Moreira, A.G. (2000). Effects of fire protection on savanna structure in central Brazil. J. Biogeogr. 27, 1021-1029.

Nardoto, G.B., Bustamante, M.M.D., Pinto, A.S. \& Klink, C.A. (2006). Nutrient use efficiency at ecosystem and species level 
in savanna areas of central Brazil and impacts of fire. J. Trop. Ecol. 22, 191-201.

Nogueira, C., Colli, G.R. \& Martins, M. (2009). Local richness and distribution of the lizard fauna in natural habitat mosaics of the Brazilian Cerrado. Austral Ecol. 34, 83-96.

Oksanen, L. (2001). Logic of experiments in ecology: is pseudoreplication a pseudoissue? Oikos 94, 27-38.

Oliveira, P.S. \& Marquis, R.J. (2002). The Cerrados of Brazil. Ecology and Natural History of a Neotropical Savanna. New York: Columbia University Press.

Ortega, J., López, P. \& Martín, J. (2014). Conspicuous blue tails, dorsal pattern morphs and escape behaviour in hatchling Iberian wall lizards (Podarcis hispanicus). Biol. J. Linn. Soc. 113, 1094-1106.

Pafilis, P., Foufopoulos, J., Poulakakis, N., Lymberakis, P. \& Valakos, E.D. (2009). Tail shedding in island lizards [Lacertidae, Reptilia]: decline of antipredator defenses in relaxed predation environments. Evolution 63, 1262-1278.

Peig, J. \& Green, A.J. (2009). New perspectives for estimating body condition from mass/length data: the scaled mass index as an alternative method. Oikos 118, 1883-1891.

Peig, J. \& Green, A.J. (2010). The paradigm of body condition: a critical reappraisal of current methods based on mass and length. Funct. Ecol. 24, 1323-1332.

Pérez-Mellado, V., Corti, C. \& LoCascio, P. (1997). Tail autotomy and extinction in Mediterranean lizards. A preliminary study of continental and insular populations. $J$. Zool. 243, 533-541.

Pianka, E.R. \& Huey, R.B. (1978). Comparative ecology, resource utilization and niche segregation among gekkonid lizards in the southern Kalahari. Copeia 1978, 691-701.

Pike, D.A., Croak, B.M., Webb, J.K. \& Shine, R. (2010). Context-dependent avoidance of predatory centipedes by nocturnal geckos (Oedura lesueurii). Behaviour 147, 397-412.

Pivello, V.R., Oliveras, I., Miranda, H.S., Haridasan, M., Sato, M.N. \& Meirelles, S.T. (2010). Effect of fires on soil nutrient availability in an open savanna in Central Brazil. Plant Soil 337, 111-123.

R Core Team (2014). R: A Language and Environment for Statistical Computing. Available at: http://www.R-project.org.

Ramos, A.M., dos Santos, L.A.R. \& Fortes, L.T.G. (2009). Normais Climatológicas do Brasil 1961-1990. Brasília, DF: INMET.

Recoder, R., Werneck, F., Teixeira, M., Colli, G., Sites, J. \& Rodrigues, M. (2014). Geographic variation and systematic review of the lizard genus Vanzosaura (Squamata, Gymnophthalmidae), with the description of a new species. Zool. J. Linn. Soc.-Lond. 171, 206-225.

Renous, S., Hofling, E. \& Gasc, J.P. (1998). Respective role of the axial and appendicular systems in relation to the transition to limblessness. Acta. Biotheor. 46, 141-156.

Renous, S., Hofling, E. \& Gasc, J.P. (1999). On the rhythmical coupling of the axial and appendicular systems in small terrestrial lizards (Sauria: gymnophthalmidae). Zool.-Anal. Complex Sy. 102, 31-49.
Renous, S., Hofling, E. \& Bels, V. (2008). Locomotion patterns in two South American gymnophthalmid lizards: Vanzosaura rubricauda and Procellosaurinus tetradactylus. Zoology 111, 295-308.

Ribeiro, M.L.O. (2011). Reserva Ecológica do IBGE Biodiversidade Terrestre. Rio de Janeiro: Fundação Instituto Brasileiro de Geografia e Estatística - IBGE.

Salvador, A. \& Veiga, J.P. (2005). Activity, tail loss, growth and survivorship of male Psammodromus algirus. AmphibiaReptilia 26, 583-585.

Santos, M.G., Nogueira, C., Giugliano, L.G. \& Colli, G.R. (2014). Landscape evolution and phylogeography of Micrablepharus atticolus (Squamata, Gymnophthalmidae), an endemic lizard of the Brazilian Cerrado. J. Biogeogr. 41, 1506-1519.

Schoener, T.W. (1979). Inferring the properties of predation and other injury-producing agents from injury frequencies. Ecology 60, 1110-1115.

Schoener, T.W. \& Spiller, D.A. (1996). Devastation of prey diversity by experimentally introduced predators in the field. Nature 381, 691-694.

Sousa, H.C., Soares, A.H.B., Costa, B.M., Pantoja, D.L., Caetano, G.H., Queiroz, T.A. \& Colli, G.R. (2015). Fire regimes and the demography of the lizard Micrablepharus atticolus (Squamata, Gymnophthalmidae) in a biodiversity hotspot. S. Am. J. Herpetol. 10, 143-156.

Tanner, D. \& Perry, J. (2007). Road effects on abundance and fitness of Galapagos lava lizards (Microlophus albemarlensis). J. Environ. Manage. 85, 270-278.

Tubelis, D.P. \& Cavalcanti, R.B. (2001). Community similarity and abundance of bird species in open habitats of a central Brazilian cerrado. Ornitol. Neotrop. 12, 57-73.

Valenti, M.W., Cianciaruso, M.V. \& Batalha, M.A. (2008). Seasonality of litterfall and leaf decomposition in a Cerrado site. Braz. J. Biol., 68, 459-465.

Vieira, G.H.C., Mesquita, D.O., Péres, A.K. Jr, Kitayama, K. \& Colli, G.R. (2000). Micrablepharus atticolus (NCN). Natural history. Herpetol. Rev. 31, 241-242.

Vitt, L.J. (1981). Tail autotomy and regeneration in the tropical skink, Mabuya heathi. J. Herpetol. 15, 454-457.

Vitt, L.J. (1991). An introduction to the ecology of Cerrado lizards. J. Herpetol. 25, 79-90.

Vitt, L.J. \& Caldwell, J.P. (1993). Ecological observations on Cerrado lizards in Rondônia, Brazil. J. Herpetol. 27, 46-52.

Vitt, L.J. \& Cooper, W.E. (1986). Tail loss, tail color, and predator escape in Eumeces (Lacertilia, Scincidae): agespecific differences in costs and benefits. Can. J. Zool. 64, 583-592.

Vitt, L.J., Congdon, J.D. \& Dickson, N.A. (1977). Adaptive strategies and energetics of tail autotomy in lizards. Ecology 58, 326-337.

Warton, D.I., Wright, I.J., Falster, D.S. \& Westoby, M. (2006). Bivariate line-fitting methods for allometry. Biol. Rev. 81, 259-291.

Wiens, J.J., Brandley, M.C. \& Reeder, T.W. (2006). Why does a trait evolve multiple times within a clade? Repeated 
evolution of snakeline body form in squamate reptiles. Evolution 60, 123-141.

Wolf, A.J., Hellgren, E.C., Bogosian, V. \& Moody, R.W. (2013). Effects of habitat disturbance on Texas horned lizards: an urban case study. Herpetologica 69, 265-281.
Wrinn, K.M. \& Uetz, G.W. (2008). Effects of autotomy and regeneration on detection and capture of prey in a generalist predator. Behav. Ecol. 19, 1282-1288.

Zani, P.A. (1996). Patterns of caudal-autotomy evolution in lizards. J. Zool. 240, 201-220. 


\section{Capítulo 3: Regimes de queima e a demografia de Tropidurus itambere (Tropiduridae,}

\section{Squamata) em um hotspot de biodiversidade: viabilidade populacional sob diferentes}

\section{históricos de queima}

Nesta nova era em que a Terra entrou, conhecer como a variação do clima e os distúrbios afetam as taxas vitais dos animais e que, consequentemente, levam a mudanças no crescimento populacional é essencial para a mitigação dos efeitos antrópicos. O fogo é um distúrbio importante presente em ecossistemas inflamáveis de todo o mundo, incluindo campos e savanas. Porém, pouco se sabe sobre os efeitos do clima e do fogo sobre populações animais, especialmente no hotspot de biodiversidade do Cerrado. Neste estudo de longo prazo de marcação e recaptura, objetivou-se investigar os efeitos do clima e de diferentes regimes de queima com diferentes graus de severidade sobre a estrutura etária (baseada em médias mensais dos tamanhos corporais dos indivíduos) e a demografia do lagarto Tropidurus itambere. Com o auxílio de modelos de projeção integrados, foram investigadas as taxas vitais específicas do tamanho que mais contribuem para o crescimento populacional. Foi encontrado que a temperatura e a insolação foram os preditores mais importantes da estrutura etária e dos parâmetros demográficos, e o período de recrutamento sempre ocorrendo nos meses de janeiro, apesar da variação climática. A espécie é menos abundante nos regimes de queima mais extremos, seja na supressão do fogo, seja em queimadas frequentes e intensas no final da estação seca. Queimadas frequentes e intensas no final da estação seca prejudicam a persistência da espécie porque diminuem as taxas de recrutamento e sobrevivência, provavelmente devido à redução na disponibilidade de recursos alimentares e micro-hábitats para os ovos e para indivíduos adultos. A sobrevivência, crescimento e nascimento de jovens são os parâmetros que mais contribuem para o crescimento populacional na espécie, portanto o manejo deve ser voltado para 
estes indivíduos. Com base em outros estudos e em nossos resultados, sugere-se que queimadas de baixa intensidade e extensão durante o final da estação chuvosa devem beneficiar espécies de sucessão precoce como T. itambere e espécies de sucessão tardia, como algumas aves e pequenos mamíferos, pois criam hábitats adequados para a sobrevivência e recrutamento e ainda evitam incêndios de alta intensidade em áreas extensas que ocorrem no final da estação seca. Mudanças climáticas que afetem os padrões normais de temperatura e insolação devem ter altos impactos sobre populações de animais ectotérmicos, como o lagarto T. itambere. 
Fire regimes and demography of Tropidurus itambere (Tropiduridae, Squamata) in a biodiversity hotspot: population viability in different fire histories

Heitor C. de Sousa ${ }^{1}$, Bernardo M. Costa ${ }^{2}$, Carlos José S. Morais ${ }^{1}$, Davi L. Pantoja ${ }^{1}$, Tânia A. de Queiroz $^{1}$, Guarino R. Colli ${ }^{1}$

1 Departamento de Zoologia, Universidade de Brasília, 70910-900 Brasília, DF, Brasil 2 Instituto Federal de Brasília, Campus Gama, Lote 01, DF 480, Setor de Múltiplas Atividades, 72429-005, Gama, DF, Brasil

Correspondence: Guarino R. Colli, Departamento de Zoologia, Universidade de Brasília, 70910900 Brasília, DF, Brasil. Email: grcolli@unb.br 


\section{Abstract}

In this new Age that Earth entered, knowing how climate variation and disturbances affects animal vital rates and consequently drives changes in population growth is essential for mitigating the anthropic effects. Fire is a major disturbance present in flammable ecosystems worldwide, including grasslands and savannas. However, little is known about the effects of climate and fire on animal populations, especially in the Cerrado biodiversity hotspot. In this long-term of markrecapture study, we aimed to investigate the effects of climate and of different histories of fire on the age structure (based on monthly mean body sizes) and the demography of the Cerrado endemic lizard Tropidurus itambere. With aid of integrated projection models (IPMs), we also investigated the size-specific vital rates that contribute more to population growth and predicted population sizes after 50 years. We found that temperature and insolation were the most important predictors for the age structure and demographic parameters and timing of recruitment was always in January, despite of the climate variation between the years. The species is less abundant in the most extreme regimes of fire, with suppression of fire and frequent late-dry intense fires. Frequent late-dry intense fires also harm the populations persistence, because those decrease the recruitment and survival rates, presumably due to the lack of microhabitat and food resources availability for eggs and individuals. Populations of T. itambere are in great decline, with great risks of extinction after 50 years, probably because of the suppression of fire, thus creating unsuitable habitats for the species. The survival, growth and birth of younglings most contribute to the population growth in the species, thus management should be invested in these individuals. We conclude that small lowintense fires prescribed in the wet season shall benefit early successional species as $T$. itambere and late successional, as birds and small mammals, because they create suitable habitats for survival and recruitment and avoid extense and high intense fires in the dry season. Changes in the 
normal distributions of temperature and insolation must have high impacts on populations of ectothermic animals, such as T. itambere. 


\section{INTRODUCTION}

Animal population dynamics depend on the species vital rates (e.g. survival, growth and fecundity) and on how these rates are regulated by abiotic and biotic factors (Tinkle 1967; Stearns 1977). Abiotic factors include climate conditions and stochastic perturbations, such as fire and droughts (Inger \& Greenberg 1966; Letnic et al. 2004; Read et al. 2012). Temperature and rainfall are the main factors that influence the population dynamics of the organisms (Adolph \& Porter 1996; Ogutu et al. 2008; Altwegg \& Anderson 2009). These factors are important in tropical environments, where there is low temperature variation, but considerable variation in rainfall (Andrews \& Nichols 1990; Andrews 1991; Brown \& Shine 2006). On the other hand, the climatic conditions and perturbations drive important biotic factors, including predation(Wilson \& Cooke 2004; Madsen et al. 2006), competition (Ballinger 1976; Massot et al. 1992), and food resources (Ballinger 1977; Dunham 1978; Prevedello et al. 2013).

Annual temperature variation may affect the length of the days of activity (Adolph \& Porter 1996) and the developments of individuals and embryos in ectothermic animals, as reptiles (Marquis, Massot \& Le Galliard 2008; Le Galliard, Marquis \& Massot 2010; Telemeco et al. 2010). Therefore, temperature may affect ultimately the growth (Braña \& Ji 2000), survival (RojasGonzález et al. 2008) and fecundity of animal populations (Baird \& Davies 1986). Additionally, variations in rainfall in the tropics affect biomass vegetation and the abundances of many animals that are source of food to other animals, leading to effects on higher trophic levels (Lemos-Espinal, Smith \& Ballinger 2003; White 2013; Ujvari et al. 2015). Rainfall also affects the levels of air humidity, which influence on the embryos development and survival and post-hatching fitness of lizards (e.g. survival, growth, locomotor performance) (Stamps \& Tanaka 1981; Lorenzon et al. 1999; Warner \& Shine 2007). The cloud cover and insolation may also affect survival, activity, 
recruitment, age structure and growth of reptile populations because they influence on thermal opportunities (Hare \& Cree 2010; Sousa et al. 2015).

Fire is a perturbation present in fire-prone ecosystems, including savannas and grasslands and it is getting more frequent worldwide (Bond \& Keeley 2005; Bond, Woodward \& Midgley 2005; Bowman et al. 2009). Fire has major importance in ecosystem processes and also contributes to global greenhouse gas budgets (Beringer et al. 2015; Edwards, Russell-Smith \& Meyer 2015). In tropical savannas, natural fires occur by lightning ignitions or by human activities (Ramos-Neto \& Pivello 2000; Bond \& Keeley 2005). Fires initiated by humans tend to happen in the late dry season, when air humidity is low, fuel is dry and abundant, and wind intensity is higher (Mistry 1998). In addition, human activities generate fire regimes more frequent, intense, broader in scale, and more difficult to control in comparison to the natural regimes (Miranda, Bustamante \& Miranda 2002; Miranda et al. 2009; Bowman et al. 2011). Fire frequency and intensity opens the canopy cover and increases the grass cover of fire-prone ecosystems, because it increases the tree mortality (Bond \& Keeley 2005; Bond, Woodward \& Midgley 2005; Miranda 2010). Yet, fires may affect animal community diversity and composition (Andersen et al. 2005; Watson et al. 2012a; Pastro, Dickman \& Letnic 2014), but little is known about the effects of fire on animal populations, which may be more instructive for management and conservation (Driscoll et al. 2010; Duff, Bell \& York 2013; Smith, Michael Bull \& Driscoll 2013).

Because fires are natural and relatively frequent perturbations in savannas, the organisms may have adopted adaptive strategies to cope with them (Simon et al. 2009; Brennan, Moir \& Wittkuhn 2011; Avitabile et al. 2015). Accordingly, lizards have behavior adaptations to protect themselves in the passage of fire, as burrowing in holes and termite mounds (Russell, Lear \& Guynn Jr. 1999; Costa et al. 2013). However, because of their different ecologies and physiologies, 
species respond differently to the secondary effects of fire on the vegetation structure and they may specialize in different stages in the succession of vegetation after fire (Masters 1996; Smith, Michael Bull \& Driscoll 2013). In animals, fire may change the species habitat (Pianka 1996; Hailey 2000; Haslem et al. 2011), physiology (Stawski et al. 2015), behavior (Griffiths \& Christian 1996; Faria, Lima \& Magnusson 2004), food resources (Andersen et al. 2005; Radford \& Andersen 2012), predation rates (Karpestam, Merilaita \& Forsman 2012), thermal opportunities (Lelièvre $e t$ al. 2013) and social interactions (Breininger et al. 2014). Therefore, the varied effects of post-fire changes on reptiles hamper their predictions (Driscoll \& Henderson 2008; Lindenmayer et al. 2008). These changes may influence the vital rates of the animal populations, as survival and recruitment, which in turn, may affect the age structure and long-term population growth rates. Fire may also affect capture probability, or detectability, of animals and many studies neglect this factor because of the high costs in obtaining such data (Driscoll et al. 2010; Driscoll et al. 2012; Smith, Bull \& Driscoll 2012). Unfortunately, neglecting this factor often biases the conclusions about the effects of fire on animal populations (Driscoll et al. 2012; Guimarães, Doherty \& Munguía-Steyer 2014).

In the new age that Earth entered, the Anthropocene, management towards conservation of biodiversity is critical to reduce the present rates of species extinction (Steffen et al. 2011; Zalasiewicz et al. 2011; Lewis \& Maslin 2015). Global climate changes and habitat destruction drive the species extinction of many vertebrates in the world (Dirzo et al. 2014), with considerable impacts on reptiles (Sinervo et al. 2010; Böhm \& al 2013). Habitat loss and harvesting are the main factors that threat one in five reptiles in the world (Böhm \& al 2013). Similarly, the biodiversity hotspot of Cerrado is under increasing threat, with high rates of land conversion and endemic species (Mittermeier et al. 1998; Myers et al. 2000; Klink \& Machado 2005). Moreover, gap 
analysis revealed that $91 \%$ of the endemic lizards from Cerrado are under-represented in the current scenario of protected areas (Silva et al. 2014). In addition to these numbers, fires are increasing worldwide and we do not know how these perturbations affect most of the animal populations (Driscoll et al. 2010; Bowman et al. 2011), and more critically, those from Cerrado (Frizzo et al. 2011). Demographic studies may help to understand the needs and dangers in variable conditions that species face upon to, and which factors may affect the population extinction risks probability (Clarke 2008; Templeton, Brazeal \& Neuwald 2011). Integrated projection models that use age or size-specific estimates may also determine which sizes are more sensitive and contribute more to the population growth rates (Easterling, Ellner \& Dixon 2000; Stubben, Milligan \& Nantel 2012; Merow et al. 2014).

In this paper, we present results of a long-term monitoring study that aimed to investigate the demography of an endemic lizard from a Neotropical savanna Tropidurus itambere Rodrigues, 1987 in areas with different fire regimes, estimating its vital rates (survival and recruitment) and detecting the most important size classes that contribute to population growth, based on integrated projection models. Tropidurus itambere is a diurnal, heliophilous, and territorialist ambush forager, has a fast-growing strategy, and it is sexually reproductive in the first year of life (Rodrigues 1987; Van Sluys 1997; Van Sluys 1998; Rocha et al. 2009). The species seems to present multiple clutches in each reproductive season that vary between one and eight eggs, and the recruitment happens in the wet season (Van Sluys 1993b; Van Sluys 2000). It feeds upon several arthropods and invertebrates (Van Sluys 1993a). Our main hypothesis predict that the species benefits from the more frequent and intense fire histories, because the species is present in more open physiognomies and in severe fire regimes (Van Sluys 2000; Pantoja 2007b; Carvalho 2013). In these fire regimes, we expect that age structure (represented as monthly means of SVL) presents 
more young individuals, populations are larger, present higher rates of survival, capture, and recruitment, leading to higher population growth rates.

\section{MATERIAL AND METHODS}

\section{Study area}

We conducted this study at Reserva Ecológica do IBGE, RECOR (1556'41"S, 4753'07"W), Brasília, Distrito Federal, Brazil, in the core of the Cerrado biome (Eiten 1972). Climate is markedly seasonal, with a wet season from October to April, followed by a dry season from May to September (Nimer 1989). From 1972 to 1990, the RECOR was fully protected from fires. In 1989, however, a long-term experiment was initiated to evaluate the effects of different burn regimes upon animals and plants (Miranda 2010; Pivello et al. 2010; Miranda et al. 2011). A uniform sampling area was divided into 10 ha plots, each submitted to a different regime, characterized by a combination of the timing (early dry season: in late June, middle dry season: in early August, and late dry season: in late September) and frequency (biennial and quadrennial) of burns. In addition, there were control, unburned plots. Because plots were placed in the same physiognomy and shared the same history of burns prior to the onset of the experiment, we assumed that differences between plots through time arose from the effects of prescribed burn regime histories. We selected five plots (Figure 1) in the cerrado sensu stricto physiognomy (Ribeiro \& Walter 1998): three subjected to prescribed biennial burns (early biennial - EB, middle biennial $\mathrm{MB}$, and late biennial - LB), one subjected to prescribed quadrennial burns (middle quadrennial $\mathrm{Q})$, and one control plot (C). Fire severity increased along the sequence $\mathrm{C} \rightarrow \mathrm{Q} \rightarrow \mathrm{EB} \rightarrow \mathrm{MB} \rightarrow$ LB. The last prescribed burns occurred in 2007 in quadrennial plots (five burns in each plot) and 


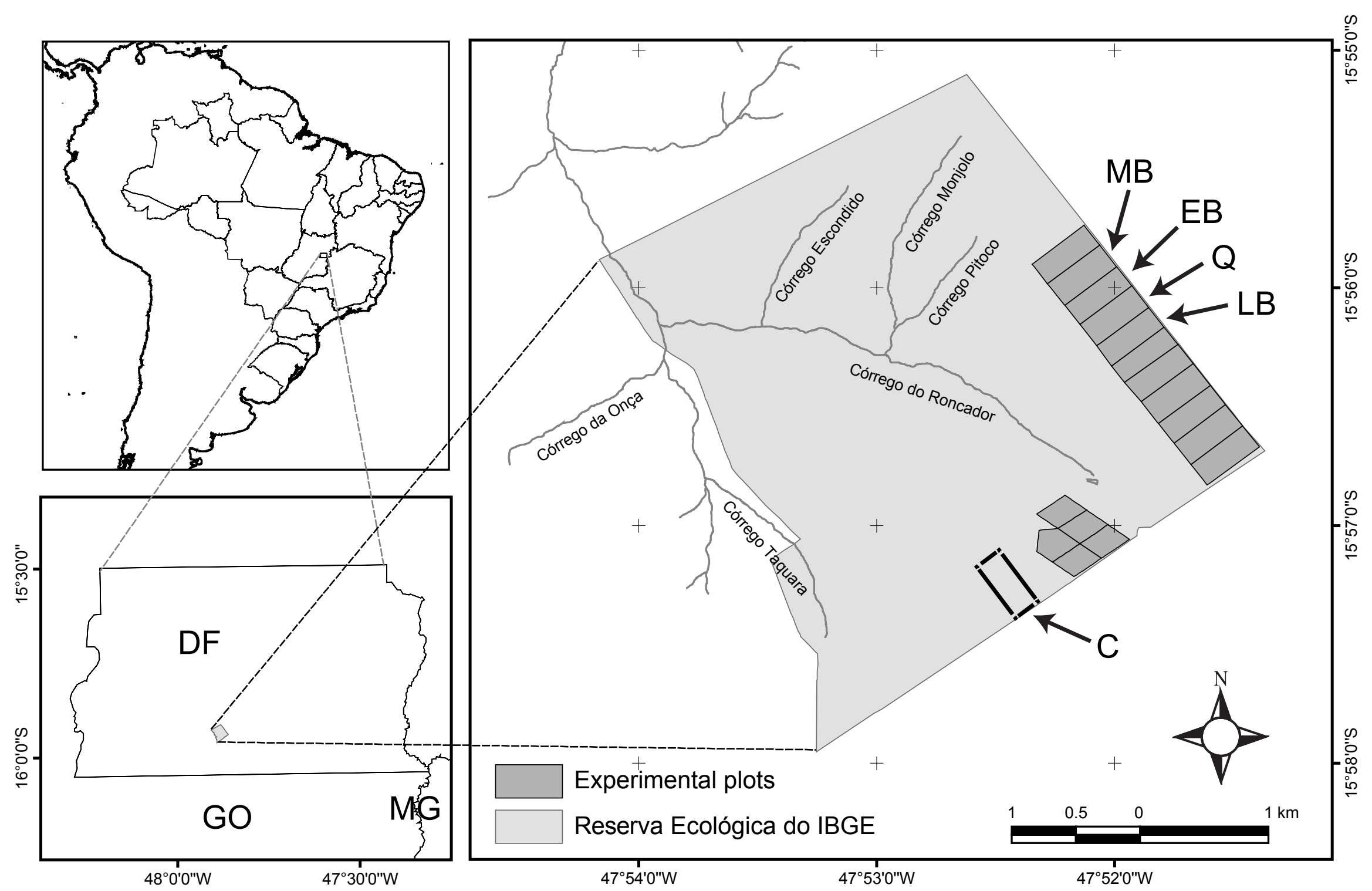

Figure 1. Map with location of the studied plots: late biennial (LB), modal biennial (MB), early biennial (EB), quadrennial $(Q)$ and the control without fire until 2011 (C). 
2008 in biennial plots (nine burns in each plot). In September 2011, an unplanned fire partially burned the LB, and completely burned the control plot. With the exception of the C plot, all other plots were adjacent to each other, separated by a ca. 5m-wide dirt road Figure 1). In addition to the costs and difficulties of replication typical of large-scale ecologic studies (Carpenter, 1990; Oksanen, 2001), our experiment could not be replicated because of legal issues associated with burning the vegetation inside protected areas. We recognize this reduces the statistical power of our study, but such large-scale manipulative experiments are the only way to ensure the availability of adequate treatment levels (Driscoll et al. 2010). Therefore, we restrict our statistical inferences to the study areas, considering our sampling methodology as adequate to represent them.

\section{Population monitoring}

From November 2005 to December 2014, we monitored the populations of Tropidurus itambere in study plots, capturing animals with the aid of pitfall traps. Description of traps can be found elsewhere (Sousa et al. 2015). We opened the traps every month, during six consecutive days, and checked daily. Considering the distance between transects in adjacent plots (ca. $200 \mathrm{~m}$ ), the small size and territorialist behavior of the study species (Van Sluys 1997; Van Sluys 2000) and the dirt road separating adjacent plots, we did not expect lizard movements between adjacent plots to affect our results. Indeed, during the entire period of this study there was not a single recapture indicative of movements between plots. We recorded the SVL (with a ruler, $1 \mathrm{~mm}$ precision) and sex of each captured lizard, followed by individual marking (toe clipping) and release at the capture site. We determined the sex by hemipenis eversion in males and also by visually assessing the presence of eggs in females. Individuals that could not be sexed in the capture or next recaptures, we considered as juveniles. To assess differences in the number of captures or recaptures among plots, we used 
sequential chi-square tests, removing variables (plots) from analyses based on their chi-square residuals until differences among plots were no longer significant (Zar 2010).

\section{Age structure}

To identify seasonal or cyclic patterns and trends in the age structure of the lizard population in each plot, we transformed monthly means of SVL into time series. As we captured no lizards in some months/plots, and the time-series analyses cannot have missing data, we used multiple imputations (Rubin 1996; Zhang 2003) to replace missing data and estimate statistical parameters, with package Amelia II (Honaker, King \& Blackwell 2012) in R (R Core Team 2015) as in (Sousa et al. 2015). We included the monthly means of climatic variables obtained from the RECOR meteorological station: precipitation (precip), evaporation (evap), relative air humidity (humid), insolation (sun), average air temperature (tmed), maximum air temperature (tmax) and minimum air temperature (tmin); to improve prediction (Honaker, King \& Blackwell 2012).

We built a correlogram to identify cyclic patterns in SVL variation and created cyclic sine and cosine wave patterns along the months and among the years to assess the influence of climatic variables upon monthly means of SVL. We used an information-theory approach (Burnham \& Anderson 2002), based on the Akaike information criterion corrected for finite sample sizes (AIC c $_{\text {), }}$ to select linear mixed-effects (LME) models relating monthly means of SVL to climatic variables, with packages lme4 (Bates et al. 2014) and MuMIn (Bartón 2014) of R (R Core Team 2015). Because evaporation is highly correlated to air humidity (>0.90) and we did not have any hypothesis relating it to SVL, we excluded it from the models selection. We undertook an exhaustive screening of all possible models to assess predictor importance, determined as the sum of the Akaike weights for all models containing a given predictor, and retained those where $\Delta \mathrm{AIC}_{\mathrm{c}}$ 
$\leq 2$ to assess predictor coefficients (Burnham \& Anderson 2002). To account for the temporal pseudoreplication resulting from plots being sampled several times over the course of the study, we used the sine and cosine wave patterns previously identified and year as random factors in the LME models (Crawley 2013).

We used LME models to assess differences in SVL among plots along the year. In this analysis, we used fire regime (plot) as fixed factor and year (2005 to 2014) as a random factor. We assessed the significance of the fixed factors and their interaction by comparing the full model with simpler models, sequentially dropping terms and using a significance test $\left(\chi^{2}\right)$ of the reduction in scaled deviance (Crawley 2013). We conducted all analyses in R (R Core Team 2015) and used a significance level of $5 \%$ in hypothesis testing.

\section{Demographic analyses}

We used individual capture histories of Tropidurus itambere from November 2005 to November 2014 to assess the effects of climate variables and fire regime histories on estimates of demographic parameters. We used Pradel models, which estimate the probabilities of apparent survival $(\Phi)$, capture $(p)$ and recruitment $(f)$. With these parameters, the model is also able to derive the finite population growth $(\lambda)$. We implemented the analyses in two steps, using RMark 2.1.14 (Laake 2013) and MARK 8.0 (White \& Burnham 1999). In the first step, we used model selection and model averaging to identify climate variables that best explain capture histories. We started the analysis with a general model, where $\Phi, p$, and $f$ were constrained by all climatic variables. To ensure that this general model adequately fitted the data, we conducted a goodness-of-fit (GOF) test, by comparing our general model with a saturated model where survival and recapture probabilities were constrained by the interaction of fire regime history and capture occasion 
$\left(\Phi\left(g^{*} t\right), p\left(g^{*} t\right)\right)$, with U-CARE 2.3.2 (Choquet et al. 2009b). Next, we conducted a heuristic stepwise model selection based on AICc, retaining those models with $\triangle \mathrm{AICc} \leq 2$ (Burnham \& Anderson 2002). Finally, we assessed parameter importance as indicated above.

In the second step, we used model selection and model averaging to identify fire-related variables that best explain capture histories. Thus, we constrained $\Phi, p$, and $f$ by the climate variables identified in the first step and by burn frequency (biennial, quadrennial, and control), timing (late, middle, early and control), regime history ( $\mathrm{LB}, \mathrm{MB}, \mathrm{EB}, \mathrm{Q}$, and C), a continuous vector indicating the time (in months) since last fire in each plot (TSLF), and a binomial vector indicating the occurrence of fire in each plot (0: no fire, 1: fire). Therefore, we attempted to model both the long-term (frequency, time, regime history, TSLF) and short-term (occurrence) effects of fire, accounting for variation in climate. We conducted model selection and averaging as indicated above, in the first step.

Age-specific life tables and integral projection models

To estimate the life expectancy and produce age-specific life-tables we used individual capture histories among the years in the package BaSTA (Colchero, Jones \& Rebke 2013). BaSTA uses Bayesian analyses coupled with Markov chain Monte Carlo (MCMC) methods to model agespecific survival from capture-recapture data in the presence of covariates (Colchero \& Clark 2012). The following parameters were used in this analysis: Gompertz mortality function (model="GO") with a Makeham shape (shape="Makeham"), ten MCMC simulations (nsim=10) each with $10^{5}$ iterations (niter=100,000), sampled at each 100 iterations (thinning=100), and discarding the first $10^{4}$ iterations as burnin (burnin=10,001). Multiple runs were performed in parallel (parallel=T, ncpus=4), using package snowfall (Knaus 2013). 
We constructed integral projection models (IPMs) according to (Merow et al. 2014) (Appendixes 1 and 2) with the aid of package IPMpack (Metcalf et al. 2013). We built regressions of survival and growth predicted by size (SVL) for all the fire regimes with our own time series data (Figures S1, S2 and S3). In this analysis, if an individual was never recaptured in the next capture events, it was considered dead. To account for detectability, we took annual means of capture probability estimated by MARK in the previous section and divided the probability of surviving and growing by the capture probability in each fire regime. To predict fecundity, we gathered data from Paracatu, Minas Gerais, which we have information about clutch size and SVL of 67 reproductive individuals of Tropidurus itambere. We found females with both ovules and vitellogenic follicles, evidencing multiple clutches in the species (Van Sluys 1993b).To be more realistic, we considered as double the clutch size for the females larger than the smallest female with presence of ovules and vitellogenic follicles (more than an offspring per season). With the regressions for each fire regime, we produced five kernels of 50 grids that describes how the size distribution of individuals changes over time. These kernels can be split into a survival/growth kernel, and a fecundity kernel (Merow et al. 2014). The survival/growth kernel describes the probability that an individual survives over a month and grow (Merow et al. 2014). The fecundity kernel describes the number of offspring produced by reproductive individuals during the census interval, and the size distribution of those new offspring (Merow et al. 2014). In each fecundity function from the five fire regimes, we included the survival probability from the offspring produced as the maximum value from recruitment estimated by MARK. With those kernels, we made elasticity analyses based on the eigenvalues and eigenvectors in package popbio (Stubben \& Milligan 2007). To estimate the quasi-extinction probability based on the kernels in the next 100 years of populations from each fire regime, we simulated for structured populations in an independently and identically distributed stochastic environment with the function stoch.quasi.ext 
from package popbio (Stubben \& Milligan 2007) with 10 runs of 5000 iterations, with an initial population size of 4789 individuals distributed with sizes based on a normal distribution, and with a quasi-extinction probability threshold of 100 individuals. We also calculated the probability of quasi-extinction in the next 100 years with threshold of 100 individuals for the populations in each fire regime incorporating demographic stochasticity with the function multiresultm, from package popbio (Stubben \& Milligan 2007)

\section{RESULTS}

In nine years and one month, we marked 1083 individuals of Tropidurus itambere in the five plots, with 1609 captures and recaptures that result in 0.33 of average recapture. Eight hundred and eighty individuals were only captured once. The maximum number of recaptures from one individual was six times. There were no differences in the captures and recaptures in the early and middle biennial plots (captures: $\chi_{1}{ }^{2}=0.10323, P=0.748$; recaptures: $\chi_{1}{ }^{2}=1.48, P=0.2238$ ), which had significantly more captures and recaptures than the plots with different fire regimes (Figure 2, sequential $\chi^{2}$ tests, $\left.P<0.001\right)$. On the other side, we captured and recaptured less in this increasing order: control, quadrennial and for last in the late biennial plot (Figure 2, sequential $\chi^{2}$ tests, $P<$ $0.001)$.

There is a clear seasonal variation in the SVL temporally, with little overlap between the generations (years) (Figure 3). The autocorrelation analysis of monthly means of SVL based on 1000 imputed datasets revealed that the temporal autocorrelation is highest for a gap of 12 months (mean $a c f=0.71$ ), what demonstrates that the age structure has an annual cycle. Hatchlings appear from January to April, at the middle to the end of the rainy season. Reproduction occurs during the end of the dry and beginning of the rainy season: we found only two females bearing eggs, one in 


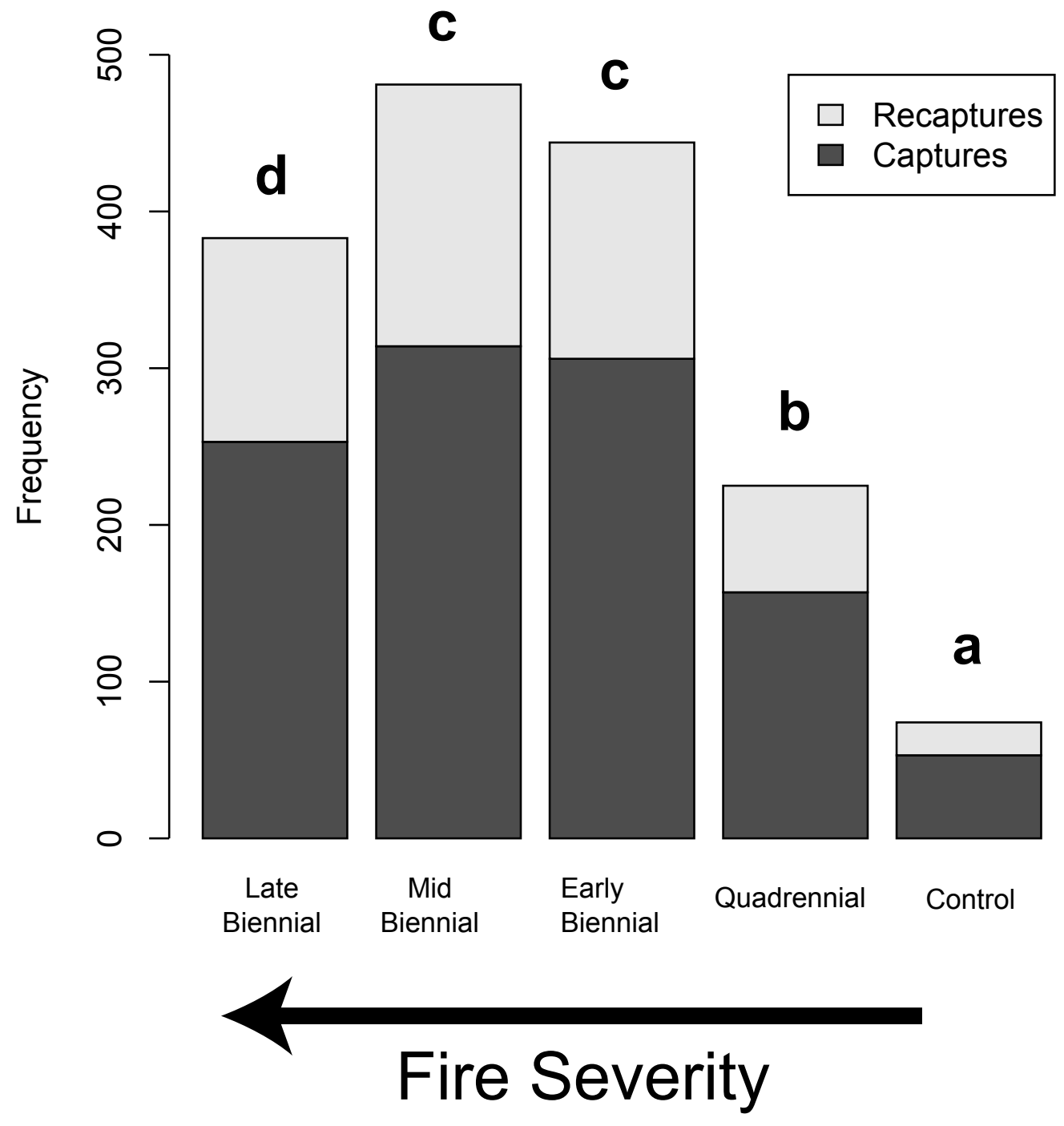

Figure 2. Captures and recaptures of Tropidurus itambere in cerrado sensu stricto control and treatment plots of varying fire severity, in central Brazil. Asterisks indicate plots where captures and recaptures differed from the remainder. 


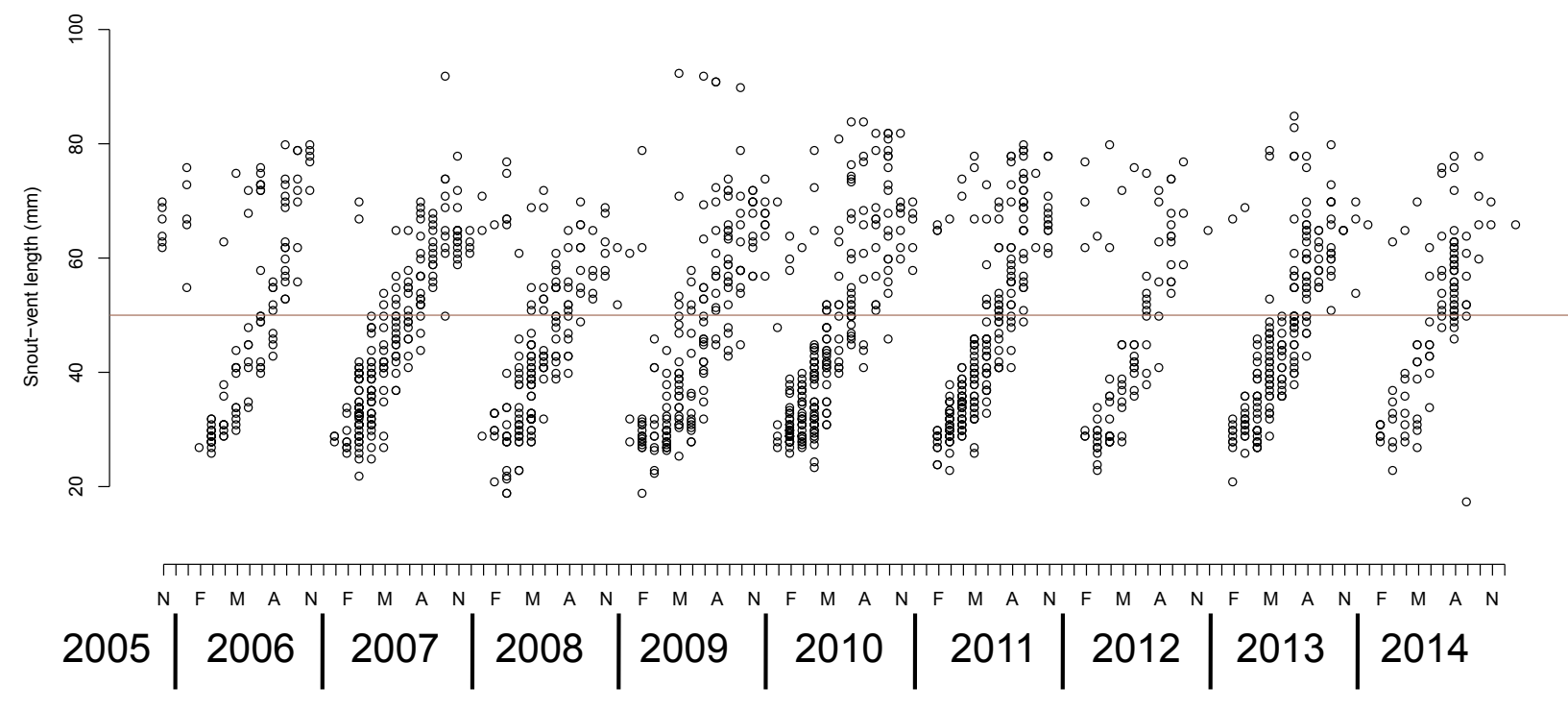

Figure 3. Snout-vent length (SVL) of Tropidurus itambere captured from 2005 to 2014, in cerrado sensu stricto control and treatment plots of varying fire severity, in central Brazil. Dashed line indicates SVL at sexual maturity $(50 \mathrm{~mm})$. 


\section{Survival}

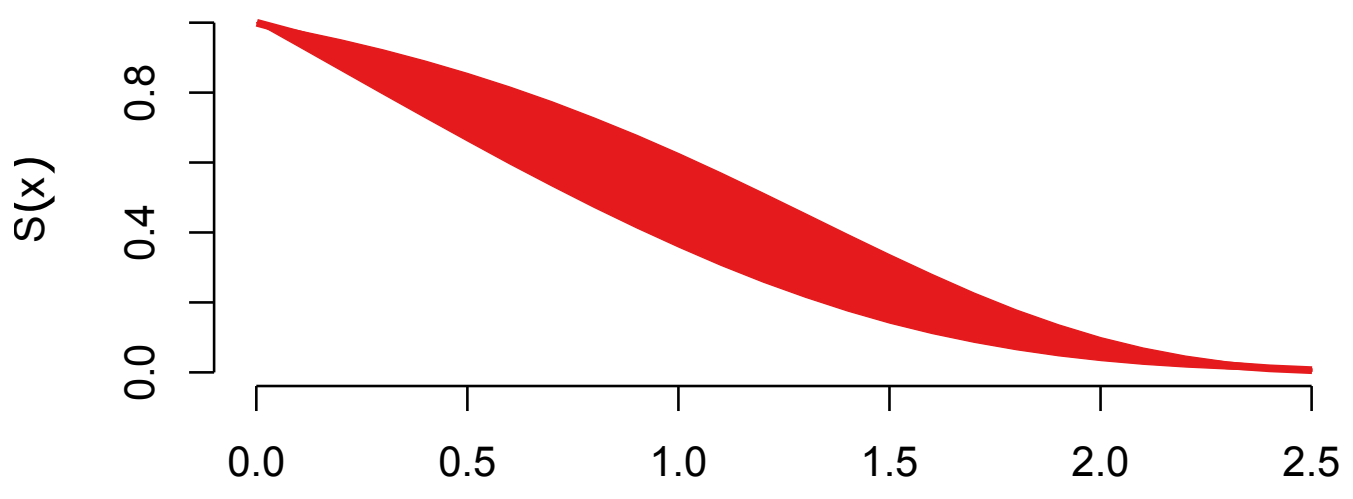

\section{Mortality}

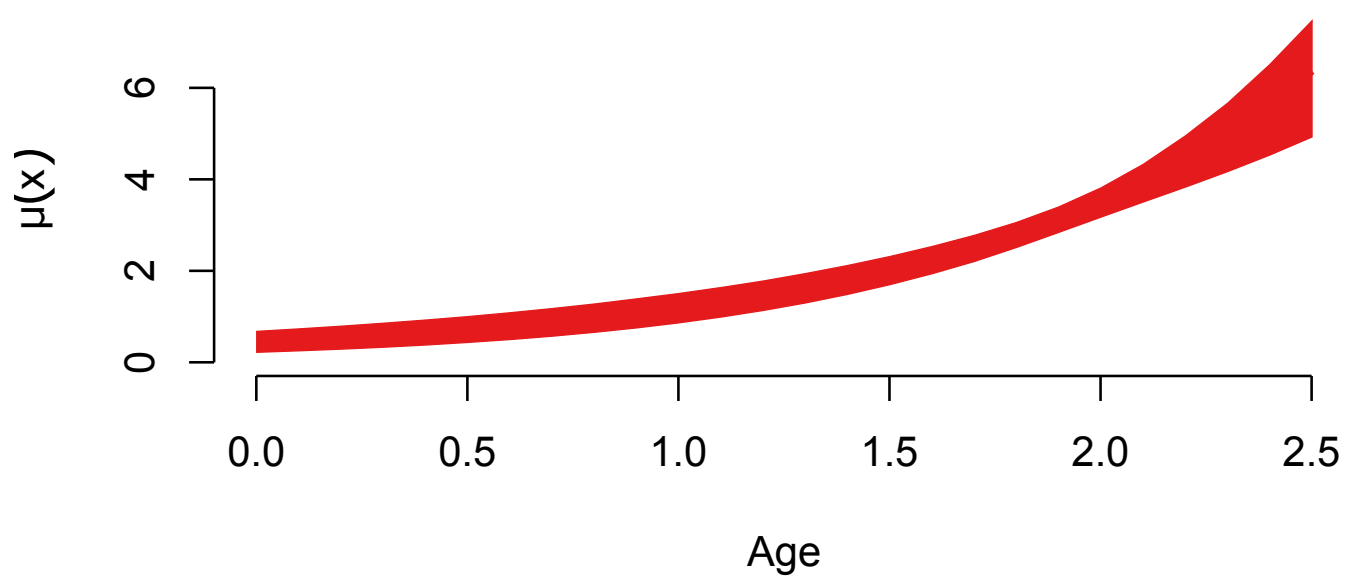

Figure 4. Predicted survival probability and mortality rate of Tropidurus itambere at Reserva Ecológica do IBGE, Brasília, Distrito Federal, Brazil. The width of the survival probability and mortality rate polygons corresponds to the $95 \%$ credible intervals. 
September and another in November. Bayesian analysis in the capture histories indicated that individuals have constant mortality during life, with a life span of two and a half years, at maximum (Figure 4). In summary, the species presents an annual life cycle with low survivorship (Figure 4), breeding takes place at the end of the dry season to the beginning of the rainy season, and hatchlings appearing at the middle to the end of the rainy season (Figure 3).

The model selection of LME models relating monthly means of SVL to the climate variables retained two models, all containing, besides the seasonality (sine and cosine waves factors), the variables of temperature averages (minimum, mean and maximum) (Table 1). Means of SVL increased when values of temperature (minimum, mean and maximum) were low. The SVL did not vary among the plots (i.e., no significant effect of dropping the interaction term and fire history upon the scaled deviance; $\chi^{2}{ }_{[4]}=4.216, P=0.377$ ), nor the interaction between months of capture and the plots (i.e., no significant effect of dropping the interaction term upon the scaled deviance; $\left.\chi^{2}{ }_{[4]}=6.124, P=0.19\right)$, indicating no difference in the age structure among the different histories of fire (Figure 5). The means of SVL were affected significantly only by the months of the year (i.e., significant increase in scaled deviance after dropping all fixed effects and their interaction; $\left.\chi^{2}[1]=331, P<0.001\right)$ (Figure 6).

The demographic analyses with probability of survival $(\Phi)$, capture $(p)$, and recruitment $(f)$ constrained by climate variables retained eleven models with $\Delta \mathrm{AICc} \leq 2$ (Table 2 ). All the variables contained in the most parsimonious model had $100 \%$ of importance in a model-averaging analysis (Table2), and insolation was the only important predictor of all three demographic parameters. In the second step of model selection with $\Phi, p$, and $f$ constrained by the climate variables identified in the first step and fire frequency, timing, history, occurrence, and time since the last fire, a single model with $\triangle \mathrm{AICc} \leq 2$ was retained: $\Phi \quad(T S L F+$ frequency + tmin + sun + humid $)$ 
Table 1. Coefficients, Akaike information criterion adjusted for small samples $\left(\mathrm{AIC}_{\mathrm{c}}\right)$, and relative variable importance of two linear mixed-effects models, where $\Delta \mathrm{AIC}_{\mathrm{c}} \leq 2$, relating monthly means of the SVL of Tropidurus itambere to climate predictors, in Reserva Ecológica do Roncador RECOR, Brasília, Distrito Federal, Brazil, from November 2005 to December 2014. Precipitation (precip), relative air humidity (humid), insolation (sun), average air temperature (tmed), maximum air temperature (tmax), minimum air temperature (tmin) and sin and cos waves depicting the seasonal variation.

\begin{tabular}{llll}
\hline Parameter & Model 1 & Model 2 & Importance \\
\hline $\mathrm{AIC}_{\mathrm{c}}$ & 745.83 & 747.49 & \\
Intercept & $102.391 \pm 13.244$ & $102.255 \pm 14.174$ & - \\
cos waves & $18.706 \pm 1.019$ & $18.804 \pm 1.031$ & 1.00 \\
sin waves & - & - & 0.00 \\
tmed & $-2.315 \pm 0.593$ & - & 0.70 \\
tmax & - & $-1.593 \pm 0.526$ & 0.30 \\
tmin & & $-0.504 \pm 0.281$ & 0.30 \\
insol & - & - & 0.00 \\
humid & - & - & 0.00 \\
precip & - & - & 0.00 \\
\hline
\end{tabular}




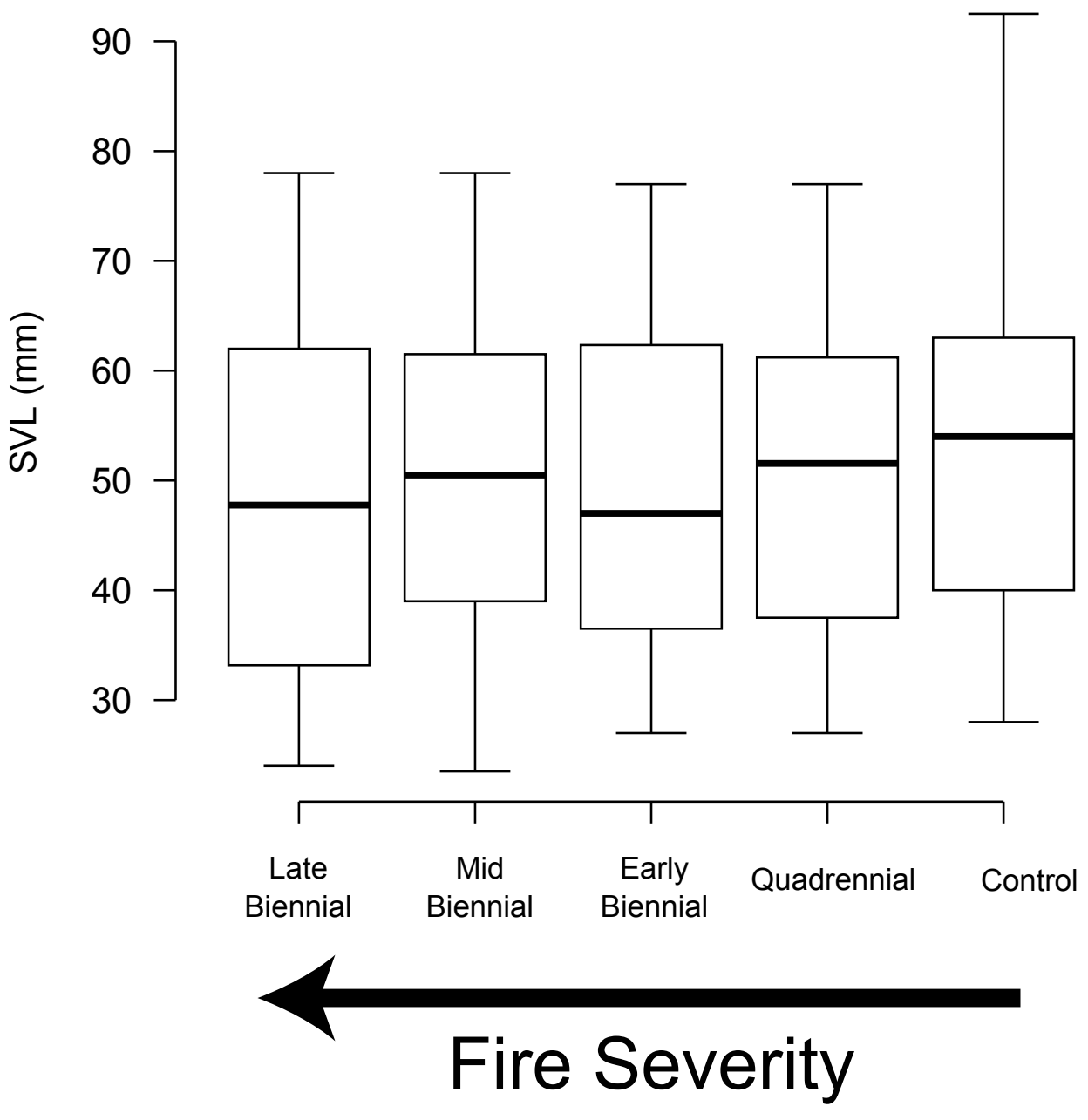

Figure 5. Snout-vent length (SVL) variation of Tropidurus itambere in cerrado sensu stricto control and treatment plots of varying fire severity in central Brazil. Boxplot depicts median (solid bar) and interquartile range (box). Whiskers extend as far as $1.5 \mathrm{x}$ the interquartile range or to minimum and maximum SVL. 


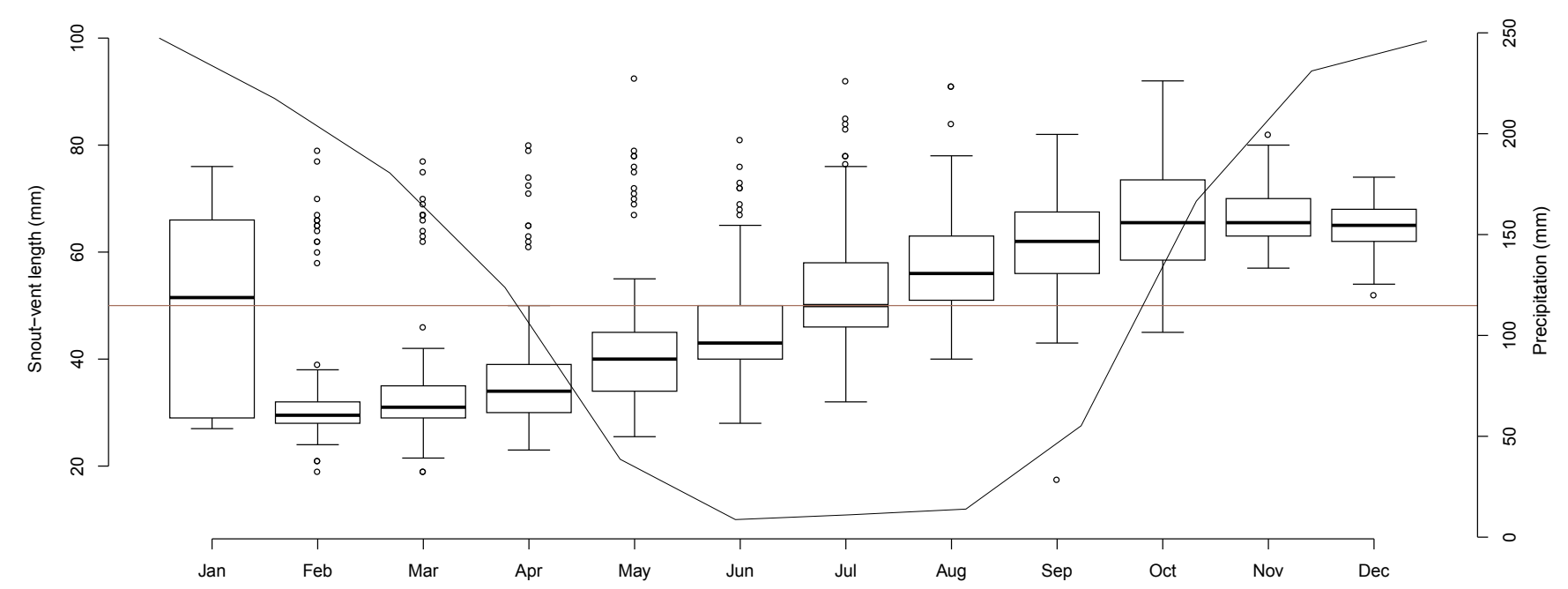

Figure 6. Monthly variation in precipitation and snout-vent length (SVL) of Tropidurus itambere captured from 2005 to 2013, in cerrado sensu stricto control and treatment plots of varying fire severity, in central Brazil. Boxplot depicts median (solid bar) and interquartile range (box). Whiskers extend as far as 1.5x the interquartile range or to minimum and maximum SVL. Dashed line indicates SVL at sexual maturity $(50 \mathrm{~mm})$. Curve represents average precipitation in Brasília, Distrito Federal, from 1961-1990

(Source: Instituto Nacional de Meteorologia - INMET). 
Table 2. Best Pradel models estimating the probabilities of survival $(\Phi)$, recapture $(p)$ and recruitment $(f)$ of Tropidurus itambere in Brasília, Distrito Federal, Brazil, from November 2005 to December 2014, constrained by climate variables. precip: precipitation; humid: relative air humidity; sun: insolation; tmax: maximum air temperature; tmed: average air temperature; tmin: minimum air temperature; and $\sin$ and $\cos$ waves depicting the seasonal variation; AICc: Akaike information criterion corrected for small sample size; wAICc: Akaike weight.

\begin{tabular}{|c|c|c|c|}
\hline Model & $\mathrm{AICc}$ & wAICc & Deviance \\
\hline $\begin{array}{l}\Phi(\text { tmin }+ \text { humid }+ \text { sun }) p(\text { sun }+ \text { tmed }+\sin +\cos +\operatorname{tmax}+\text { precip }) f(\sin +\cos + \\
\text { tmed }+ \text { sun }+ \text { tmax }+ \text { tmin })\end{array}$ & 12447.9 & 0.170561 & 2475.799 \\
\hline $\begin{array}{l}\Phi(\text { tmin }+ \text { humid }+\operatorname{sun}+\sin +\cos ) p(\operatorname{sun}+\text { tmed }+\sin +\cos +\text { tmax }+ \text { precip }) \\
f(\sin +\cos +\text { tmed }+\operatorname{sun}+\text { tmax }+ \text { tmin })\end{array}$ & 12448.04 & 0.159414 & 2471.821 \\
\hline $\begin{array}{l}\Phi(\text { tmin }+ \text { humid }+ \text { sun }) p(\text { sun }+ \text { tmed }+\sin +\cos +\operatorname{tmax}+\text { precip }) f(\sin +\cos + \\
\text { tmed }+ \text { sun }+ \text { tmax }+ \text { tmin }+ \text { precip })\end{array}$ & 12448.91 & 0.102955 & 2474.754 \\
\hline $\begin{array}{l}\Phi(\text { tmin }+ \text { humid }+ \text { sun }) p(\text { sun }+ \text { tmed }+\sin +\cos +\text { tmax }+ \text { precip }+ \text { humid }) f(\sin \\
+\cos +\text { tmed }+ \text { sun }+ \text { tmax }+ \text { tmin })\end{array}$ & 12449.33 & 0.083537 & 2475.172 \\
\hline $\begin{array}{l}\Phi(\text { tmin }+ \text { humid }+\operatorname{sun}+\sin +\cos ) p(\text { sun }+ \text { tmed }+\sin +\cos +\text { tmax }+ \text { precip }) \\
f(\sin +\cos +\text { tmed }+\operatorname{sun}+\text { tmax }+ \text { tmin }+ \text { precip })\end{array}$ & 12449.58 & 0.073605 & 2471.305 \\
\hline $\begin{array}{l}\Phi(\text { tmin }+ \text { humid }+ \text { sun }) p(\text { sun }+ \text { tmed }+\sin +\cos +\text { tmax }+ \text { precip }+ \text { tmin }) f(\sin + \\
\text { cos }+ \text { tmed }+ \text { sun }+ \text { tmax }+ \text { tmin })\end{array}$ & 12449.58 & 0.073501 & 2475.427 \\
\hline $\begin{array}{l}\Phi(\text { tmin }+ \text { humid }+\operatorname{sun}+\sin +\cos ) p(\operatorname{sun}+\text { tmed }+\sin +\cos +\text { tmax }+ \text { precip }) \\
f(\sin +\cos +\text { tmed }+\operatorname{sun}+\text { tmax }+ \text { tmin }+ \text { humid })\end{array}$ & 12449.62 & 0.072256 & 2471.342 \\
\hline $\begin{array}{l}\Phi(\text { tmin }+ \text { humid }+ \text { sun }+ \text { tmed }) p(\text { sun }+ \text { tmed }+\sin +\cos +\text { tmax }+ \text { precip }) f(\sin \\
+\cos +\text { tmed }+ \text { sun }+ \text { tmax }+ \text { tmin })\end{array}$ & 12449.77 & 0.066873 & 2475.617 \\
\hline $\begin{array}{l}\Phi(\text { tmin }+ \text { humid }+ \text { sun }+\sin +\cos ) p(\operatorname{sun}+\text { tmed }+\sin +\cos +\text { tmax }+ \text { precip }+ \\
\text { tmin }) f(\sin +\cos +\text { tmed }+\operatorname{sun}+\operatorname{tmax}+\text { tmin })\end{array}$ & 12449.79 & 0.066302 & 2471.513 \\
\hline $\begin{array}{l}\Phi(\text { tmin }+ \text { humid }+ \text { sun }) p(\text { sun }+ \text { tmed }+\sin +\cos +\text { tmax }+ \text { precip }) f(\sin +\cos + \\
\text { tmed }+ \text { sun }+ \text { tmax }+ \text { tmin }+ \text { humid })\end{array}$ & 12449.8 & 0.065943 & 2475.644 \\
\hline $\begin{array}{l}\Phi(\text { tmin }+ \text { humid }+ \text { sun }+\sin +\cos ) p(\text { sun }+ \text { tmed }+\sin +\cos +\text { tmax }+ \text { precip }+ \\
\text { humid }) f(\text { sin }+\cos +\text { tmed }+\operatorname{sun}+\text { tmax }+ \text { tmin })\end{array}$ & 12449.83 & 0.065054 & 2471.551 \\
\hline
\end{tabular}


$p($ occurrence+frequency + sun + tmed + sin_cos + tmax + precip $) \quad f($ history+ $) \quad$ sin_cos + tmed+sun+tmax+tmin $)(\mathrm{AICc}=12,378.371$, deviance $=2,387.661)$. In this model, survival and capture probabilities were best explained by fire frequency, whilst recruitment was affected by the fire history. In addition, the time since last fire affected the survival and the fire occurrence affected the capture probability. The demographic parameters exhibited regular, cyclical patterns throughout the years (Figure7).

The survival probability varied seasonally, driven by variations in insolation, air humidity and minimum temperatures, with higher survival in the wet season (Figure7, Table 3). It is important to notice that survival rates had higher variations when compared to capture and recruitment parameters (influence of sine and cosine waves) (Figure7, Table 3). Survival was negatively affected by the time since last fire in all fire regimes. However, survival rates were highest in quadrennial and lowest in biennial frequencies of fire (Figure7, Table 3). The capture probability increases at the middle of the wet season and reaches the peaks in the middle to the end of the dry season (when the mean temperatures are highest), when it decreases again (Figure7, Table 3). Recruitment was surprisingly fixed between the years, with one peak each year and always in January (Figure7, Table 3). Therefore, the recruitment is positively affected by high mean temperatures and low insolation, and when the extremes of temperature are lower (Figure7, Table 3). The fire histories affected the recruitment, with lowest rates in quadrennial histories, and with the highest rates in the early and middle biennial regime histories (Figure7, Table 3). Population growth rates are constant in all fire regimes (Table 4).

The integral projection models revealed that the survival probability is not constant along the growth of the individuals (Supplementary Information). In all fire regimes, survival contributes more than $70 \%$ to the population growth, while fecundity contributes with less than $30 \%$, based on 


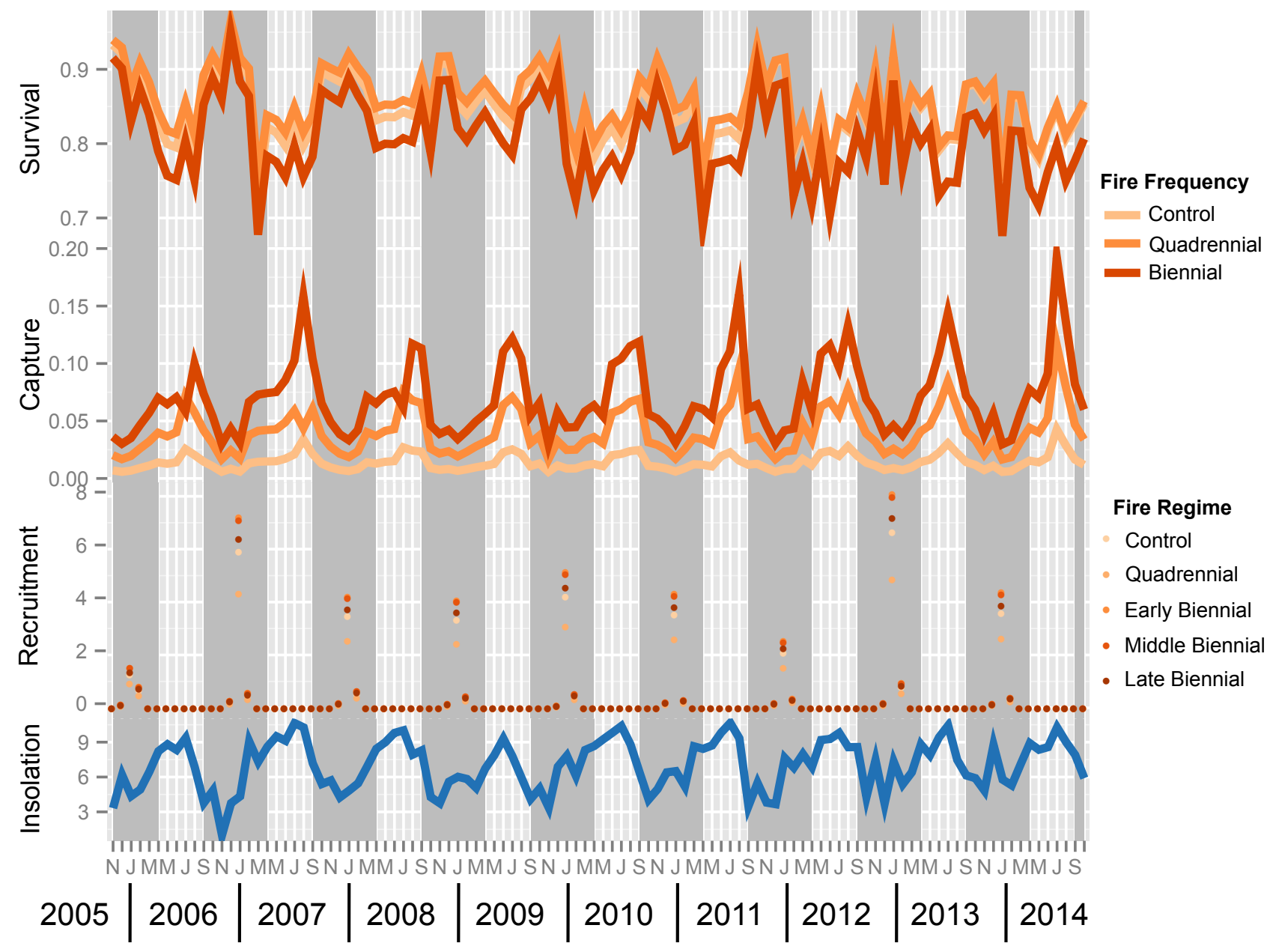

Figure 7. Estimates of apparent survival, capture and recruitment rates of Tropidurus itambere from cerrado sensu stricto control and treatment plots of varying fire severity in central Brazil, from 2005 to 2013. Blue line indicates the monthly variation of insolation (Source: RECOR meteorological station). 
Table 3. Demographic analysis of Tropidurus itambere in plots subjected to controlled burns, in Brasília, Distrito Federal, Brazil, from November 2005 to December 2014. Values represent estimates of demographic parameters and coefficients of strata and covariates of the Pradel model $\Phi$ $($ TSLF+frequency+tmin+sun+humid $)$ $p($ occurrence + frequency + sun + tmed + sin_cos + tmax + precip $)$ $f($ history+sin_cos + tmed + sun+tmax + tmin $)$. Coefficients ( $\boldsymbol{\beta}) \Phi:$ probability of survival, $p$ : probability of capture, $f$ : per capita recruitment. Strata: burn frequency (control, quadrennial and biennial), regime (control, quadrennial, early biennial, middle biennial and late biennial), time since last fire (TSLF) and fire occurrence (yes, no).

\begin{tabular}{|c|c|c|}
\hline Parameter & Estimate $( \pm \mathrm{SD})$ & $\beta( \pm \mathrm{SE})$ \\
\hline \multicolumn{3}{|l|}{$\Phi$} \\
\hline Intercept (Biennial) & $0.808 \pm 0.055$ & $6.546 \pm 1.226$ \\
\hline Control & $0.847 \pm 0.045$ & $0.326 \pm 0.284$ \\
\hline Quadrennial & $0.858 \pm 0.043$ & $0.366 \pm 0.129$ \\
\hline$T S L F$ & - & $-0.000197 \pm 0.000324$ \\
\hline $\operatorname{tmin}$ & - & $-0.065 \pm 0.031$ \\
\hline humid & - & $-0.027 \pm 0.012$ \\
\hline sun & - & $-0.322 \pm 0.073$ \\
\hline \multicolumn{3}{|l|}{$p$} \\
\hline Intercept (Biennial) & $0.07 \pm 0.032$ & $-6.462 \pm 0.853$ \\
\hline Control & $0.014 \pm 0.007$ & $-1.675 \pm 0.539$ \\
\hline Quadrennial & $0.04 \pm 0.019$ & $-0.599 \pm 0.196$ \\
\hline fire & - & $-0.817 \pm 0.285$ \\
\hline $\sin$ & - & $-0.679 \pm 0.122$ \\
\hline $\cos$ & - & $0.2 \pm 0.078$ \\
\hline sun & - & $0.121 \pm 0.034$ \\
\hline tmed & - & $0.608 \pm 0.107$ \\
\hline $\operatorname{tmax}$ & - & $-0.386 \pm 0.094$ \\
\hline precip & - & $0.001 \pm 0.001$ \\
\hline \multicolumn{3}{|l|}{$f$} \\
\hline Intercept (Control) & $0.369 \pm 1.144$ & $-23.62 \pm 2.141$ \\
\hline Quadrennial & $0.27 \pm 0.836$ & $-0.313 \pm 0.401$ \\
\hline Early Biennial & $0.449 \pm 1.394$ & $0.198 \pm 0.369$ \\
\hline Mid Biennial & $0.442 \pm 1.371$ & $0.181 \pm 0.37$ \\
\hline Late Biennial & $0.398 \pm 1.235$ & $0.077 \pm 0.371$ \\
\hline
\end{tabular}




\begin{tabular}{lll}
$\sin$ & - & $16.411 \pm 2.348$ \\
$\cos$ & - & $-1.259 \pm 0.798$ \\
tmed & - & $1.747 \pm 0.062$ \\
sun & - & $-0.078 \pm 0.035$ \\
tmax & - & $-1.028 \pm 0.062$ \\
tmin & - & $-0.154 \pm 0.062$ \\
\hline
\end{tabular}


Table 4. Annual geometric means of finite population growth rates $( \pm \mathrm{SE})$ of Tropidurus itambere in plots subjected to controlled burns, in Brasília, Distrito Federal, Brazil, from November 2005 to December 2014.

\begin{tabular}{llllll}
\hline Year & Control & Quadrennial & Early Biennial & Mid Biennial & Late Biennial \\
\hline 2005 & $0.933 \pm 0.027$ & $0.94 \pm 0.018$ & $0.916 \pm 0.024$ & $0.916 \pm 0.024$ & $0.916 \pm 0.024$ \\
2006 & $0.977 \pm 0.062$ & $0.965 \pm 0.033$ & $0.962 \pm 0.037$ & $0.96 \pm 0.037$ & $0.95 \pm 0.036$ \\
2007 & $1.056 \pm 0.081$ & $1.036 \pm 0.044$ & $1.042 \pm 0.048$ & $1.04 \pm 0.048$ & $1.026 \pm 0.046$ \\
2008 & $1.039 \pm 0.071$ & $1.021 \pm 0.04$ & $1.028 \pm 0.047$ & $1.026 \pm 0.047$ & $1.013 \pm 0.045$ \\
2009 & $1.032 \pm 0.061$ & $1.015 \pm 0.032$ & $1.021 \pm 0.036$ & $1.02 \pm 0.035$ & $1.008 \pm 0.035$ \\
2010 & $1.015 \pm 0.069$ & $1 \pm 0.037$ & $0.999 \pm 0.04$ & $0.997 \pm 0.04$ & $0.985 \pm 0.039$ \\
2011 & $1 \pm 0.068$ & $0.985 \pm 0.039$ & $0.979 \pm 0.044$ & $0.978 \pm 0.044$ & $0.967 \pm 0.043$ \\
2012 & $0.963 \pm 0.066$ & $0.942 \pm 0.037$ & $0.927 \pm 0.04$ & $0.926 \pm 0.04$ & $0.917 \pm 0.039$ \\
2013 & $1.082 \pm 0.075$ & $1.046 \pm 0.042$ & $1.053 \pm 0.047$ & $1.051 \pm 0.046$ & $1.038 \pm 0.045$ \\
2014 & $1.011 \pm 0.073$ & $0.982 \pm 0.042$ & $0.978 \pm 0.045$ & $0.976 \pm 0.045$ & $0.965 \pm 0.043$ \\
\hline Total & $1.018 \pm 0.069$ & $0.998 \pm 0.038$ & $0.997 \pm 0.042$ & $0.996 \pm 0.042$ & $0.984 \pm 0.041$ \\
\hline
\end{tabular}


the elasticity analyses. The elasticity analyses of the integral projection models indicated that the recruitment provided by the larger individuals contribute significantly to the population growth (Supplementary Information). However, the most important parameters to the population growth are the survival and growth of individuals between 25 and $35 \mathrm{~mm}$ (Supplementary Information). In all biennial plots, populations presented higher survival for smaller individuals in comparison to the other plots and consequently presented higher long-term finite population growth rates compared to the other fire regimes (Supplementary Information). The stochastic projections indicated that the population submitted to mid quadrennial fires must go to extinction in about 20 years with $100 \%$ of probability, due to the low survivorship from smaller individuals and low recruitment rates. While in the other plots, quasi-extinction probability is negligible $(0 \%)$.

\section{DISCUSSION}

In this study, the climate seasonality and the perturbations caused by fire regimes affected the demography of Tropidurus itambere. To our knowledge, this is the first study to assess the extinction risks of an endemic animal from a Neotropical savanna of biodiversity hotspot based on integral projection models. Our results also present the size-specific vital rates of a species which benefits from specific fire regimes, which may elucidate questions about resilience of organisms to perturbations, as fire and climate variations. The low survivorship, short life-span (2.5 years), and the thermal preferences of the species show that even much abundant species may become threatened face to human disturbances, as global climate change and harmful fire regimes. In this study, we also found that other climatic conditions rather than rainfall and temperature might affect animal populations in tropical and seasonal environments, mainly those with ectothermic physiologies. 
Our results demonstrated that the climate seasonality in the Neotropical savanna affects the life cycles of Tropidurus itambere. The age structure varies along the year, with an abrupt drop of mature individuals between the generations, due to the high mortality rates and by the hatchlings. Hatchlings appear in the middle of the wet season, grow, reach sexual maturity and reproduce in the next breeding season, which happens in the middle to the end of the dry season. Individuals suffer constant high mortality rates along the aging, living up until 2.5 years in maximum. These findings were similar to a population in the southeast of Brazil (Van Sluys 1993b; Van Sluys 1998; Van Sluys 2000) and different from western populations (Ferreira, Kihara \& Mehanna 2011), however comparisons may be set cautiously, because T. itambere is a species complex (Domingos and Colli, pers. comm.). Despite of it, other allopatric and sympatric Tropidurus reproduce in other seasons of the year (Ferreira, Kihara \& Mehanna 2011), what reinforces the idea that the timing of reproduction must be a local adaptation with some physiological constraints (Shine \& Schwarzkopf 1992; Shine 2005; Warner \& Shine 2007).

Remarkably, temperature was the most important climate variable affecting the age structure and the recruitment of the species. But why is the reproduction seasonal? In the wet season, when the eggs hatch and the age structure decreases, there is higher mean temperatures and lower variations at the extremes of temperature daily. Temperature positively affects the escape behavior, the growth and fitness of embryos and hatchlings (Lorenzon et al. 1999; Braña \& Ji 2000; Samia et al. 2015). These low variations in extreme temperatures must be important for growth and survival of the young individuals, as they need to grow fast. On the other side, some reptile eggs and hatchlings are susceptible to water availability in the environment (Stamps \& Tanaka 1981; Lorenzon et al. 1999; Brown \& Shine 2006), so concentration of eggs being laid in the wet season seems a selective force of the seasonality in precipitation and air humidity over reproduction 
of T. itambere. Similarly, most Cerrado arthropods (food resource for T. itambere, mainly ants) are more abundant in the wet season (Pinheiro et al. 2002), which must be important for growth and survival of hatchlings as well. The hypothesis for lower predation on eggs and hatchlings at different times of the year may not also be discarded (Brown \& Shine 2006), however, we have little information about predation rates along the year.

One noticeable aspect is the highly cyclic recruitment rates between the years. Every year, the peak of recruitment happened in January, despite of the climatic variations between the years. This result emphasizes the importance of environment clues to the reproduction cycles and population persistence (Reed et al. 2010). Changes in normal variations of insolation and temperature may disturb populations of Tropidurus itambere, because the individuals would not have reliable clues to predict the environment.

Survival rates varied much each year, with lower rates just after the recruitment and rates remained constantly low throughout the dry season. In the dry season, when temperature and insolation were high, population was also older and capture probability was high, presumably due to high activity of individuals. These findings reveal a tradeoff between activity and survival. Male tropidurids interact socially, they are territorialist, aggressive and larger than females (Van Sluys 1997; Pinto, Wiederhecker \& Colli 2005). In the dry season, when reproductive season occurs, this behavior may expose more these individuals to predation. The high activity in the dry season (when insolation is higher) also suggests that the ectothermic physiology is a constraint factor (Dunham, Grant \& Overall 1989), not the food resources, which are more abundant in the wet season. Similarly, (Colli, Péres \& Zatz 1997) observed that fat bodies from Cerrado lizards did not decrease in the dry season, what confirms our previous statement. In 2012, we may observe high variation in insolation averages that led to lower survivorship and decreased growth rate. These findings 
emphasize that insolation must be more important to populations of ectothermic animals than temperature and precipitation because these animals depend on thermal opportunities to control their metabolisms(Hare \& Cree 2010; Read et al. 2012; Sousa et al. 2015).

Short-term effects of fire affected survival and capture probabilities. In months with fire, probability of capture were lower and survival increased with the passage of fire in all plots and decreased along the time. These results reinforces the conception that lizards survive to the passage of fire, hiding themselves in holes and other refuges (Russell, Lear \& Guynn Jr. 1999; Costa et al. 2013). In Cerrado, fires are rapid and vegetation resprouts a few days or weeks after (Mistry 1998; Miranda, Bustamante \& Miranda 2002). This burst of productivity increases the abundance of insects (Prada, Marini-Filho \& Price 1995; Vieira, Andrade \& Price 1996; Uehara-Prado et al. 2010; Lopes \& Vasconcelos 2011; Lepesqueur, Morais \& Diniz 2012), which presumably increases food resources for lizards, consequently increasing survivorship. However, the opening of the vegetation probably changes the behavior of Tropidurus itambere, due to the decrease in capture probability in months of fire. As lizards are susceptible to avian predation (Shepard 2007b; Wilgers \& Horne 2007a), individuals probably decrease their activity to enhance survival. Similar changes in behavior were observed for Chlamydosaurus kingii in Australia (Griffiths \& Christian 1996) and in Kentropyx striata, Cnemidophorus lemniscatus and Anolis auratus in an Amazonian savanna (Faria, Lima \& Magnusson 2004).

In the long term, fire histories had mixed effects upon the populations. Late dry season fires led to the lowest population growths, because of the low survival and recruitment, disproving our main hypothesis. Similarly, number of captures were lower than the other two biennial regimes. Fires that occur in the late dry season are of high intensity, because combustible fuel is dry and abundant, the air moisture is low, and wind speed is high (Mistry 1998; Miranda, Bustamante \& 
Miranda 2002; Ramos, dos Santos \& Fortes 2009). Frequent fires also decrease the soil litter and moisture (Kauffman, Cummings \& Ward 1994; Hoffmann 1996; Hoffmann \& Moreira 2002), conditions that affect the egg development of lizards (Stamps \& Tanaka 1981; Lorenzon et al. 1999; Brown \& Shine 2006). This lack of conditions for egg development may affect the recruitment of Tropidurus itambere. Survival was lower in biennial frequencies and higher in the quadrennial frequencies and control plot, because fires that are more frequent lead to opening of vegetation (Hoffmann 1996; Mistry 1998; Hoffmann 1999; Hoffmann \& Moreira 2002), which may turn lizards more susceptible to predation (Shepard 2007b; Wilgers \& Horne 2007a).

Suppression of fire in the control plot led to lower number of captures and low recruitment rates. In addition, Tropidurus itambere survival was lower as the time since last fire increased in all plots. Lack of fire in open cerrado physiognomies results in encroachment of vegetation (Moreira 2000). Therefore, thermal opportunities and food resources seem to decrease the abundance of Tropidurus itambere in denser physiognomies in late-successional vegetation, since sun penetration is hampered and because ants (which are the main composition of its diet) are more abundant in our burned areas (Maravalhas \& Vasconcelos 2014).

Elasticity analysis demonstrated that the survival and growth of young individuals between 25 and $35 \mathrm{~mm}$ contribute more to the population growth. Based on the integral projection model, the population submitted to prescribed mid quadrennial fires will present decreased long-term population growth, with a probability of $100 \%$ of quasi-extinction in the next 20 years. The main reasons for that finding is the low survivorship and growth of younger individuals and low recruitment rates. This pattern also happened for the population in the control plot (lack of fire). In contrast, populations submitted to biennial fires in the early and mid-dry seasons benefit $T$. 
itambere, because they enhance survival and growth of younger individuals and do not decrease the recruitment from the populations.

Therefore, results suggest that fire suppression and late dry season fires are very threatening managements for species like Tropidurus itambere that depend on open physiognomies to persist. Results from this study and from our previous one (Sousa et al. 2015) agree with authors that defend the management of fire in Cerrado (Durigan, Ratter \& James 2016). Late dry season fires are increasing due to increased human disturbances and to lack of management of fire inside and outside of protected areas and many times are harder to control compared to early dry season fires (Klink \& Machado 2005; Pivello 2011). Early and mid dry season biennial regimes seem beneficial for populations of Tropidurus itambere because they provide optimal habitats (Nogueira, Colli \& Martins 2009) for survival, growth and recruitment of individuals, mainly of younger ones. The studies of populations' trends are important to know the resilience of species to global changes and frequent disturbances as fire. As the responses from animals are very variable in each taxa (Driscoll \& Henderson 2008; Lindenmayer et al. 2008; Smith, Michael Bull \& Driscoll 2013; Kelly et al. 2015), we highlight the importance of studying the long-term effects of different fire regimes upon different taxons. With such knowledge, stakeholders will be able to build management plans of fire in fire-prone environments (Kelly et al. 2015). We recommend the prescription of low intense fires in small patches in the early dry season, when air humidity is high and fuel content is low. Based on knowledge and experience from other studies in savanna areas in the world, small and lowintense prescribed burns should benefit early-successional species (Nimmo et al. 2013) and latesuccessional species that are more sensitive to fires, like some small mammals and birds (Kelly et al. 2011; Kelly et al. 2012; Watson et al. 2012b; Watson et al. 2012c; Griffiths \& Brook 2014), because they avoid extensive late dry season burns. 


\section{Acknowledgments}

We thank the staff of Reserva Ecológica do IBGE for being extremely supportive and all field assistants in this long-term study. We also thank Coordenação de Apoio à Formação de Pessoal de Nível Superior - CAPES, Conselho Nacional do Desenvolvimento Científico e Tecnológico CNPq and Fundação de Apoio à Pesquisa do Distrito Federal - FAPDF for financial support.

\section{References}

Adolph, S.C. \& Porter, W.P. (1996) Growth, seasonality, and lizard life histories age and size at maturity. Oikos, 77, 267-278.

Althoff, D.M. \& Thompson, J.N. (1994) The effects of tail autotomy on survivorship and body growth of Uta stansburiana under conditions of high mortality. Oecologia, 100, 250-255.

Altwegg, R. \& Anderson, M.D. (2009) Rainfall in arid zones: possible effects of climate change on the population ecology of blue cranes. Functional Ecology, 23, 1014-1021.

Andersen, A.N., Cook, G.D., Corbett, L.K., Douglas, M.M., Eager, R.W., Russell-Smith, J., Setterfield, S.A., Williams, R.J. \& Woinarski, J.C.Z. (2005) Fire frequency and biodiversity conservation in Australian tropical savannas: implications from the Kapalga fire experiment. Austral Ecology, 30, 155-167.

Anderson, M.L., Cavalieri, C.N., Rodríguez-Romero, F. \& Fox, S.F. (2012) The differential effect of tail autotomy on sprint performance between the sexes in the lizard Uta stansburiana. Journal of Herpetology, 46, 648-652.

Andrews, R.M. (1991) Population stability of a tropical lizard. Ecology, 72, 1204-1217.

Andrews, R.M. \& Nichols, J.D. (1990) Temporal and spatial variation in survival rates of the tropical lizard Anolis limifrons. Oikos, 57, 215-221.

Arnold, E.N. (1984) Evolutionary aspects of tail shedding in lizards and their relatives. Journal of Natural History, 18, 127-169.

Arnold, E.N. (1987) Caudal autotomy as a defense. Biology of the Reptilia. Volume 16. Ecology B. Defense And Life History (eds C. Gans \& R.B. Huey), pp. 235-273. Alan R. Liss, Inc., New York.

Avitabile, S.C., Nimmo, D.G., Bennett, A.F. \& Clarke, M.F. (2015) Termites are resistant to the effects of fire at multiple spatial scales. PLoS One, 10, 1-18.

Baird, D.J. \& Davies, R.W. (1986) Life-history evolution and post reproductive mortality risk. Journal of Animal Ecology, 55, 295-302.

Ballinger, R.E. (1976) Evolution of life history strategies implications of recruitment in a lizard population following density manipulations. The Southwestern Naturalist, 21, 203-208. 
Ballinger, R.E. (1977) Reproductive strategies: food availability as a source of proximal variation in a lizard. Ecology, 58, 628-635.

Ballinger, R.E., Nietfeldt, J.W. \& Krupa, J.J. (1979) An experimental analysis of the role of the tail in attaining high running speed in Cnemidophorus sexlineatus (Reptilia: Squamata: Lacertilia). Herpetologica, 35, 114-116.

Bartón, K. (2014) MuMIn: Multi-model inference. Available from:

http://CRAN.R-project.org/package=MuMIn.

Bateman, P.W. \& Fleming, P.A. (2009) To cut a long tail short: a review of lizard caudal autotomy studies carried out over the last 20 years. Journal of Zoology, 277, 1-14.

Bateman, P.W . \& Fleming, P.A. (2011) Frequency of tail loss reflects variation in predation levels, predator efficiency, and the behaviour of three populations of brown anoles. Biological Journal of the Linnean Society, 103, 648-656.

Bates, D., Maechler, M., Bolker, B. \& Walker, S. (2014) lme4: Linear mixed-effects models using Eigen and S4.

Beringer, J., Hutley, L.B., Abramson, D., Arndt, S.K., Briggs, P., Bristow, M., Canadell, J.G., Cernusak, L.A., Eamus, D., Edwards, A.C., Evans, B.J., Fest, B., Goergen, K., Grover, S.P., Hacker, J., Haverd, V., Kanniah, K., Livesley, S.J., Lynch, A., Maier, S., Moore, C., Raupach, M., Russell-Smith, J., Scheiter, S., Tapper, N.J. \& Uotila, P. (2015) Fire in Australian savannas: from leaf to landscape. Glob Chang Biol, 21, 62-81.

Böhm, M. \& al, e. (2013) The conservation status of the world's reptiles. Biological Conservation, 157, 372-385.

Bond, W.J. \& Keeley, J.E. (2005) Fire as a global 'herbivore': the ecology and evolution of flammable ecosystems. Trends in ecology \& evolution, 20, 387-394.

Bond, W.J., Woodward, F.I. \& Midgley, G.F. (2005) The global distribution of ecosystems in a world without fire. The New phytologist, 165, 525-537.

Boozalis, T.S., LaSalle, L.T. \& Davis, J.R. (2012) Morphological and biochemical analyses of original and regenerated lizard tails reveal variation in protein and lipid composition. Comp Biochem Physiol A Mol Integr Physiol, 161, 77-82.

Bowman, D.M.J.S., Balch, J., Artaxo, P., Bond, W.J., Cochrane, M.A., D'Antonio, C.M., Defries, R., Johnston, F.H., Keeley, J.E., Krawchuk, M.A., Kull, C.A., Mack, M., Moritz, M.A., Pyne, S., Roos, C.I., Scott, A.C., Sodhi, N.S. \& Swetnam, T.W. (2011) The human dimension of fire regimes on Earth. Journal of Biogeography, 38, 2223-2236.

Bowman, D.M.J.S., Balch, J.K., Artaxo, P., Bond, W.J., Carlson, J.M., Cochrane, M.A., D'Antonio, C.M., Defries, R.S., Doyle, J.C., Harrison, S.P., Johnston, F.H., Keeley, J.E., Krawchuk, M.A., Kull, C.A., Marston, J.B., Moritz, M.A., Prentice, I.C., Roos, C.I., Scott, A.C., Swetnam, T.W., van der Werf, G.R. \& Pyne, S.J. (2009) Fire in the Earth system. Science (New York, N.Y.), 324, 481-484.

Braña, F. \& Ji, X. (2000) Influence of incubation temperature on morphology, locomotor performance, and early growth of hatchling wall lizards (Podarcis muralis). Journal of Experimental Zoology, 286, 422-433.

Breininger, D.R., Stolen, E.D., Carter, G.M., Oddy, D.M. \& Legare, S.A. (2014) Quantifying how territory quality and sociobiology affect recruitment to inform fire management. Animal Conservation, 17, 72-79.

Brennan, K.E.C., Moir, M.L. \& Wittkuhn, R.S. (2011) Fire refugia: the mechanism governing animal survivorship within a highly flammable plant. Austral Ecology, 36, 131-141. 
Brown, G.P. \& Shine, R. (2006) Why do most tropical animals reproduce seasonally? Testing hypotheses on an australian snake. Ecology, 87, 133-143.

Burnham, K.P. \& Anderson, D.R. (2002) Model Selection and Multi-Model Inference, 2nd edn. Springer-Verlag, New York.

Carvalho, A.L.G.d. (2013) On the distribution and conservation of the South American lizard genus Tropidurus Wied-Neuwied, 1825 (Squamata: Tropiduridae). Zootaxa, 3640, 42.

Chapple, D.G., McCoull, C.J. \& Swain, R. (2002) Changes in reproductive investment following caudal autotomy in viviparous skinks (Niveoscincus metallicus): lipid depletion or energetic diversion? Journal of Herpetology, 36, 480-486.

Chapple, D.G. \& Swain, R. (2002) Distribution of energy reserves in a viviparous skink: does tail autotomy involve the loss of lipid stores? Austral Ecology, 27, 565-572.

Chapple, D.G. \& Swain, R. (2004) Inter-populational variation in the cost of autotomy in the metallic skink (Niveoscincus metallicus). Journal of Zoology, 264, 411-418.

Choquet, R., Lebreton, J.-D., Gimenez, O., Reboulet, A.-M. \& Pradel, R. (2009a) U-CARE: Utilities for performing goodness of fit tests and manipulating capture-recapture data. Ecography, 32, 1071-1074.

Choquet, R., Lebreton, J.-d., Gimenez, O., Reboulet, A.-m. \& Pradel, R. (2009b) U-CARE: Utilities for performing goodness of fit tests and manipulating capture recapture data. Ecography, 32, 1071-1074.

Clarke, M.F. (2008) Catering for the needs of fauna in fire management: science or just wishful thinking? Wildlife Research, 35, 385-394.

Colchero, F. \& Clark, J.S. (2012) Bayesian inference on age-specific survival for censored and truncated data. Journal of Animal Ecology, 81, 139-149.

Colchero, F., Jones, O.R. \& Rebke, M. (2013) BaSTA: an R package for Bayesian estimation of age-specific survival from incomplete mark-recapture/recovery data with covariates. Methods in Ecology and Evolution, 3, 466-470.

Colli, G.R., Constantino, R. \& Costa, G.C. (2006) Lizards and termites revisited. Austral Ecology, 31, 417-424.

Colli, G.R., Péres, A.K. \& Zatz, M.G. (1997) Foraging mode and reproductive seasonality in tropical lizads. Journal of Herpetology, 31, 490-499.

Congdon, J.D., Vitt, L.J. \& King, W.W. (1974) Geckos: adaptive significance and energetics of tail autotomy. Science, 28, 1379-1380.

Conselho Federal de Biologia (2012) Resolução n 301. 301 (ed. CFBio). Brazil.

Cooch, E.G. \& White, G.C. (2015) Program MARK: a gentle introduction. URL: http://www.phidot.org/software/mark/docs/book/.

Cooper, W.E., Jr. (1998) Reactive and anticipatory display to deflect predatory attack to an autotomous lizard tail. Canadian Journal of Zoology, 76, 1507-1510.

Cooper, W.E., Jr. (2003) Shifted balance of risk and cost after autotomy affects use of cover, escape, activity, and foraging in the keeled earless lizard (Holbrookia propinqua). Behavioral Ecology and Sociobiology, 54, 179-187.

Cooper, W.E., Jr. (2007) Compensatory changes in escape and refuge use following autotomy in the lizard Sceloporus virgatus. Canadian Journal of Zoology, 85, 99-107.

Cooper, W.E., Jr., Prez-Mellado, V. \& Vitt, L.J. (2004) Ease and effectiveness of costly autotomy vary with predation intensity among lizard populations. Journal of Zoology, 262, 243-255.

Cooper, W.E., Jr. \& Wilson, D.S. (2010) Longer hiding time in refuge implies greater assessed risk after capture and autotomy in striped plateau lizards (Sceloporus virgatus). Herpetologica, 66, 425-431. 
Cooper, W.E., Jr., Wilson, D.S. \& Smith, G.R. (2009) Sex, reproductive status, and cost of tail autotomy via decreased running speed in lizards. Ethology, 115, 7-13.

Costa, B.M. (2011) Queimadas e lagartos do Cerrado efeitos diretos e indiretos. Master Thesis, Universidade de Brasília.

Costa, B.M., Pantoja, D.L., Vianna, M.C.M. \& Colli, G.R. (2013) Direct and short-term effects of fire on lizard assemblages from a neotropical savanna hotspot. Journal of Herpetology, 47, 502-510.

Crawley, M.J. (2013) The R Book. John Wiley \& Sons Ltd., Chichester.

Cromie, G.L. \& Chapple, D.G. (2012) Impact of tail loss on the behaviour and locomotor performance of two sympatric Lampropholis skink species. PLoS One, 7, e34732.

Daniels, C.B., Flaherty, S.P. \& Simbotwe, M.P. (1986) Tail size and effectiveness of autotomy in a lizard. Journal of Herpetology, 20, 93-96.

Dial, B.E. \& Fitzpatrick, L., C (1981) The energetic costs of tail autotomy to reproduction in the lizard Coleonyx brevis (Sauria: Gekkonidae). Oecologia, 51, 310-317.

Dirzo, R., Young, H.S., Galetti, M., Ceballos, G., Isaac, N.J. \& Collen, B. (2014) Defaunation in the Anthropocene. Science, 345, 401-406.

Domínguez-López, M.E., Ortega-león, Á.M. \& Zamora-abrego, G.J. (2015) Tail autotomy effects on the escape behavior of the lizard Gonatodes albogularis (Squamata: Sphaerodactylidae), from Córdoba, Colombia. Revista Chilena de Historia Natural, 88.

Downes, S. \& Shine, R. (2001) Why does tail loss increase a lizard's later vulnerability to snake predators? Ecology, 82, 1293-1303.

Driscoll, D.A. \& Henderson, M.K. (2008) How many common reptile species are fire specialists? A replicated natural experiment highlights the predictive weakness of a fire succession model. Biological Conservation, 141, 460-471.

Driscoll, D.A., Lindenmayer, D.B., Bennett, A.F., Bode, M., Bradstock, R.A., Cary, G.J., Clarke, M.F., Dexter, N., Fensham, R., Friend, G., Gill, M., James, S., Kay, G., Keith, D.A., MacGregor, C., Russell-Smith, J., Salt, D., Watson, J.E.M., Williams, R.J. \& York, A. (2010) Fire management for biodiversity conservation: Key research questions and our capacity to answer them. Biological Conservation, 143, 1928-1939.

Driscoll, D.A., Smith, A.L., Blight, S. \& Maindonald, J. (2012) Reptile responses to fire and the risk of post-disturbance sampling bias. Biodiversity and Conservation, 21, 1607-1625.

Duff, T.J., Bell, T.L. \& York, A. (2013) Managing multiple species or communities? Considering variation in plant species abundances in response to fire interval, frequency and time since fire in a heathy Eucalyptus woodland. Forest Ecology and Management, 289, 393-403.

Dunham, A.E. (1978) Food availability as a proximate factor influencing individual growth rates in the iguanid lizard Sceloporus Merriami. Ecology, 59, 770-778.

Dunham, A.E., Grant, B.W. \& Overall, K.L. (1989) Interfaces between biophysical and physiological ecology and the population ecology of terrestrial vertebrate ectotherms. Physiological Zoology, 62, 335-355.

Durigan, G., Ratter, J.A. \& James, J. (2016) The need for a consistent fire policy for Cerrado conservation. Journal of Applied Ecology, 53, 11-15.

Easterling, M.R., Ellner, S.P. \& Dixon, P.M. (2000) Size-specific sensitivity: applying a new structured population model. Ecology, 81, 694-708.

Edwards, A., Russell-Smith, J. \& Meyer, M. (2015) Contemporary fire regime risks to key ecological assets and processes in north Australian savannas. International Journal of Wildland Fire, 24, 857.

Eiten, G. (1972) The Cerrado vegetation of Brazil. Botanical Review, 38, 201-341. 
Faria, A.S., Lima, A.P. \& Magnusson, W.E. (2004) The effects of fire on behaviour and relative abundance of three lizard species in an Amazonian savanna. Journal of Tropical Ecology, 20, 591-594.

Faria, R.G. \& Araujo, A.F.B. (2004) Sintopy of two Tropidurus lizard species (Squamata: Tropiduridae) in a rocky Cerrado habitat in central Brazil. Brazilian Journal of Biology, 64, 775-786.

Ferreira, A., Kihara, V.O. \& Mehanna, M. (2011) Reproductive strategies of brazilian lizards of the genus Tropidurus Rodrigues, 1987 (Squamata, Tropiduridae) in the temporal and spatial. Internation Journal of Morphology, 29, 1414-1421.

Fleming, P.A., Valentine, L.E. \& Bateman, P.W. (2013) Telling tails: selective pressures acting on investment in lizard tails. Physiological and Biochemical Zoology, 86, 645-658.

Fox, S.F., Conder, J.M. \& Smith, A.E. (1998) Sexual dimorphism in the ease of tail autotomy Uta stansburiana with and without previous tail loss. Copeia, 2, 376-382.

Fox, S.F., Heger, N.A. \& Delay, L.S. (1990) Social cost of tail loss in Uta stansburiana lizard tails as status-signalling badges. Animal Behavior, 39, 549-554.

Fox, S.F. \& McCoy, K. (2000) The effects of tail loss on survival, growth, reproduction, and sex ratio of offspring in the lizard Uta stansburiana in the field. Oecologia, 122, 327-334.

Fox, S.F., Rose, E. \& Myers, R. (1981) Dominance and the acquisition of superior home ranges in the lizard Uta stansburiana. Ecology, 62, 888-893.

Fox, S.F. \& Rostker, M.A. (1982) Social cost of tail loss in Uta stansburiana. Science, 218, 692693.

Frizzo, T.L.M., Bonizário, C., Borges, M.P. \& Vasconcelos, H.L. (2011) Revisão dos efeitos do fogo sobre a fauna de formações savânicas do Brasil. Oecologia Australis, 15, 365-379.

Galdino, C.A.B., Pereira, E.G. \& Fontes, A.F. (2006) Defense behavior and tail loss in the endemic lizard Eurolophosaurus nanuzae (Squamata, Tropiduridae) from southeastern Brazil. Phyllomedusa, 5, 25-30.

Griffiths, A.D. \& Brook, B.W. (2014) Effect of fire on small mammals: a systematic review. International Journal of Wildland Fire, 23, 1034.

Griffiths, A.D. \& Christian, K.A. (1996) The effects of fire on the frillneck lizard (Chlamydosaurus kingii) in northern Australia. Australian Journal of Ecology, 21, 386-398.

Guimarães, M., Doherty, P.F. \& Munguía-Steyer, R. (2014) Strengthening population inference in herpetofaunal studies by addressing detection probability. South American Journal of Herpetology, 9, 1-8.

Hailey, A. (2000) The effects of fire and mechanical habitat destruction on survival of the tortoise Testudo hermanni in northern Greece. Biological Conservation, 92, 321-333.

Hare, K.M. \& Cree, A. (2010) Exploring the consequences of climate-induced changes in cloud cover on offspring of a cool-temperate viviparous lizard. Biological Journal of the Linnean Society, 101, 844-851.

Haslem, A., Kelly, L.T., Nimmo, D.G., Watson, S.J., Kenny, S.A., Taylor, R.S., Avitabile, S.C., Callister, K.E., Spence-Bailey, L.M., Clarke, M.F. \& Bennett, A.F. (2011) Habitat or fuel? Implications of long-term, post-fire dynamics for the development of key resources for fauna and fire. Journal of Applied Ecology, 48, 247-256.

Hawlena, D. (2009) Colorful tails fade when lizards adopt less risky behaviors. Behavioral Ecology and Sociobiology, 64, 205-213.

Hawlena, D., Boochnik, R., Abramsky, Z. \& Bouskila, A. (2006) Blue tail and striped body: why do lizards change their infant costume when growing up? Behavioral Ecology, 17, 889-896. 
Hoffmann, W.A. (1996) The effects of fire and cover on seedling establishment in a Neotropical savanna. Journal of Ecology, 84, 383-393.

Hoffmann, W.A. (1999) Fire and population dynamics of woody plants in a Neotropical savanna: matrix model projections. Ecology, 80, 1354-1369.

Hoffmann, W.A. \& Moreira, A.G. (2002) The role of fire in population dynamics of woody plants. The Cerrados of Brazil: Ecology and natural history of a neotropical savanna (eds P.S. Oliveira \& R.J. Marquis), pp. 159-177. Columbia University Press, New York.

Honaker, J., King, G. \& Blackwell, M. (2012) AMELIA II: a program for missing data.

Inger, R.F. \& Greenberg, B. (1966) Annual reproductive patterns of lizards from a Bornean rain forest. Ecology, 47, 1007-1021.

Iraeta, P., Salvador, A. \& Díaz, J.A. (2012) Effects of caudal autotomy on postnatal growth rates of hatchling Psammodromus algirus. Journal of Herpetology, 46, 342-345.

Jaksic, F.M. \& Fuentes, E.R. (1980) Correlates of tail losses in twelve species of Liolaemus lizards. Journal of Herpetology, 14, 137-141.

Karpestam, E., Merilaita, S. \& Forsman, A. (2012) Reduced predation risk for melanistic pygmy grasshoppers in post-fire environments. Ecology and Evolution, 2, 2204-2212.

Kauffman, J.B., Cummings, D.L. \& Ward, D.E. (1994) Relationships of fire, biomass and nutrient dynamics along a vegetation gradient in the Brazilian Cerrado. Journal of Ecology, 82, 519531.

Kelly, L.T., Bennett, A.F., Clarke, M.F. \& McCarthy, M.A. (2015) Optimal fire histories for biodiversity conservation. Conservation Biology, 29, 473-481.

Kelly, L.T., Nimmo, D.G., Spence-Bailey, L.M., Haslem, A., Watson, S.J., Clarke, M.F. \& Bennett, A.F. (2011) Influence of fire history on small mammal distributions: insights from a 100-year post-fire chronosequence. Diversity and Distributions, 17, 462-473.

Kelly, L.T., Nimmo, D.G., Spence-Bailey, L.M., Taylor, R.S., Watson, S.J., Clarke, M.F. \& Bennett, A.F. (2012) Managing fire mosaics for small mammal conservation: a landscape perspective. Journal of Applied Ecology, 49, 412-421.

Klink, C.A. \& Machado, R.B. (2005) Conservation of the Brazilian Cerrado. Conservation Biology, 19, 707-713.

Knaus, J. (2013) snowfall: Easier cluster computing (based on snow), R package version 1.84-6. Available at: http://CRAN.R-project.org/package=snowfall.

Kohlsdorf, T., Ribeiro, J.M. \& Navas, C.A. (2006) Territory quality and male dominance in Tropidurus torquatus (Squamata, Tropiduridae). Phyllomedusa, 5, 109-118.

Laake, J.L. (2013) RMark: an R interface for analysis of capture-recapture data with MARK. AFSC Processed Rep. 2013-01, pp. 25. Alaska Fish. Sci. Cent., NOAA, Natl. Mar. Fish. Serv., 7600 Sand Point Way NE, Seattle WA 98115.

Langkilde, T., Alford, R.A. \& Schwarkzopf, L. (2005) No behavioural compensation for fitness costs of autotomy in a lizard. Animal Ecology, 30, 713-718.

Le Galliard, J.F., Marquis, O. \& Massot, M. (2010) Cohort variation, climate effects and population dynamics in a short-lived lizard. Journal of Animal Ecology, 79, 1296-1307.

Legendre, P. (2014) lmodel2: Model II Regression.

Lelièvre, H., Rivalan, P., Delmas, V., Ballouard, J.-M., Bonnet, X., Blouin-Demers, G. \& Lourdais, O. (2013) The thermoregulatory strategy of two sympatric colubrid snakes affects their demography. Population Ecology, 55, 585-593.

Lemos-Espinal, J., Smith, G.R. \& Ballinger, R.E. (2003) Variation in growth and demography of a knob-scaled lizard (Xenosaurus newmanorum: Xenosauridae) from a seasonal tropical environment in Mexico. Biotropica, 35, 240-249. 
Lepesqueur, C., Morais, H.C. \& Diniz, I.R. (2012) Accidental fire in the cerrado: its impact on communities of caterpillars on two species of Erythroxylum. Psyche: A Journal of Entomology, 2012, 1-7.

Letnic, M., Dickman, C.R., Tischler, M.K., Tamayo, B. \& Beh, C.-L. (2004) The responses of small mammals and lizards to post-fire succession and rainfall in arid Australia. Journal of Arid Environments, 59, 85-114.

Lewis, S.L. \& Maslin, M.A. (2015) Defining the anthropocene. Nature, 519, 171-180.

Lima, S.L. \& Dill, L.M. (1990) Behavioral decisions made under the risk of predation: a review and prospectus. Canadian Journal of Zoology, 68, 619-640.

Lin, Z.H., Qu, Y.F. \& Ji, X. (2006) Energetic and locomotor costs of tail loss in the Chinese skink, Eumeces chinensis. Comparative Biochemistry and Physiology A, 143, 508-513.

Lindenmayer, D.B., Wood, J.T., Macgregor, C., Michael, D.R., Ross, B., Crane, M., Montaguedrake, R., Brown, D., Muntz, R., Driscoll, D.A., Lindenmayer, D.B., Wood, J.T., Macgregor, C., Michael, D.R., Cunningham, R.B. \& Crane, M. (2008) How predictable are reptile responses to wildfire? Oikos, 117, 1086-1097.

Lopes, C.T. \& Vasconcelos, H.L. (2011) Fire increases insect herbivory in a neotropical savanna. Biotropica, 43, 612-618.

Lorenzon, P., Clobert, J., Oppliger, A. \& John-Alder, H. (1999) Effect of water constraint on growth rate, activity and body temperature of yearling common lizard (Lacerta vivipara). Oecologia, 118, 423-430.

Lu, H.-L., Gao, J., Ma, X., Lin, Z. \& Ji, X. (2012) Tail loss affects fecundity but not offspring traits in the Chinese skink Eumeces chinensis. Current Zoology, 58, 228-235.

Lu, H.-L., Ji, X. \& Du, W.-G. (2013) Tail loss reduces locomotor ability but not metabolic rate in a viviparous skink, Sphenomorphus indicus. Animal Biology, 63, 369-380.

Madsen, T., Ujvari, B., Shine, R. \& Olsson, M. (2006) Rain, rats and pythons: Climate-driven population dynamics of predators and prey in tropical Australia. Austral Ecology, 31, 3037.

Maravalhas, J. \& Vasconcelos, H.L. (2014) Revisiting the pyrodiversity-biodiversity hypothesis: long-term fire regimes and the structure of ant communities in a Neotropical savanna hotspot. Journal of Applied Ecology, 51, 1661-1668.

Marquis, O., Massot, M. \& Le Galliard, J.F. (2008) Intergenerational effects of climate generate cohort variation in lizard reproductive performance. Ecology, 89, 2575-2583.

Martin, J. \& Salvador, A. (1992) Tail loss consequences on habitat use by the Iberian rock lizard, Lacerta monticola. Oikos, 65, 328-333.

Martin, J. \& Salvador, A. (1993a) Tail loss and foraging tactics of the Iberian rock-lizard, Lacerta monticola. Oikos, 66, 318-324.

Martin, J. \& Salvador, A. (1993b) Tail loss reduces mating success in the Iberian rock-lizard, Lacerta monticola. Behavioral Ecology and Sociobiology, 32, 185-189.

Martin, J. \& Salvador, A. (1993c) Thermoregulatory behaviour of rock lizards in response to tail loss. Behaviour, 124, 123-136.

Martin, J. \& Salvador, A. (1997) Effects of tail loss on the time-budgets, movements, and spacing patterns of iberian rock lizards, Lacerta monticola. Herpetologica, 53, 117-125.

Massot, M., Clobert, J., Pilorge, T., Lecomte, J. \& Barbault, R. (1992) Density dependence in the common lizard demographic consequences of a density manipulation. Ecology, 73, 17421756.

Masters, P. (1996) The effects of fire-driven succession on reptiles in spinifex grasslands at Uluru National Park, Northern territory. Wildlife Research, 23, 39-48. 
McConnachie, S. \& Whiting, M.J. (2003) Costs associated with tail autotomy in an ambush foraging lizard, Cordylus melanotus melanotus. African Zoology, 38, 57-65.

McCormick, S. \& Polis, G.A. (1982) Arthropods that prey on vertebrates. Biological Review, 57, 29-58.

McElroy, E.J. \& Bergmann, P.J. (2013) Tail autotomy, tail size, and locomotor performance in lizards. Physiol Biochem Zool, 86, 669-679.

McMillan, D.M. \& Irschick, D.J. (2010) Experimental test of predation and competition pressures on the green anole (Anolis carolinensis) in varying structural habitats. Journal of Herpetology, 44, 272-278.

Medel, R.G., Jiménez, J.E., Fox, S.F. \& Jaksic, F.M. (1988) Experimental evidence that high population frequencies of lizard tail autotomy indicate inefficient predation. Oikos, 53, 321324.

Merow, C., Dahlgren, J.P., Metcalf, C.J.E., Childs, D.Z., Evans, M.E.K., Jongejans, E., Record, S., Rees, M., Salguero-Gómez, R., McMahon, S.M. \& Ramula, S. (2014) Advancing population ecology with integral projection models: a practical guide. Methods in Ecology and Evolution, 5, 99-110.

Metcalf, C.J.E., McMahon, S.M., Salguero-Gómez, R., Jongejans, E. \& Rees, M. (2013) IPMpack: an R package for integral projection models. Methods in Ecology and Evolution, 4, 195200.

Miranda, H.S. (2010) Efeitos do regime do fogo sobre a estrutura de comunidades de cerrado: resultados do projeto fogo. Ministério do Meio Ambiente; Instituto Brasileiro do Meio Ambiente e dos Recursos Naturais Renováveis; Centro Nacional de Prevenção e Combate aos Incêndios Florestais., Brasília.

Miranda, H.S., Bustamante, M.M.C. \& Miranda, A.C. (2002) The fire factor. The Cerrados of Brazil: Ecology and natural history of a neotropical savanna (eds P.S. Oliveira \& R.J. Marquis), pp. 51-68. Columbia University Press, New York.

Miranda, H.S., Sato, M.N., Andrade, S.M.A., Neves, B.M.C., Quesada, C.A.N., Andrade, L.A.Z., Ramos, A.E., Medeiros, M.B., Santos, A.J.B., Cirne, P. \& Maia, J.M.F. (2011) Projeto Fogo. Reserva Ecológica do IBGE: Biodiversidade Terrestre, vol. 1 (ed. M.L. Ribeiro), pp. 163-177. IBGE, Rio de Janeiro.

Miranda, H.S., Sato, M.N., Nascimento, W.N. \& Aires, F.S. (2009) Fires in the Cerrado, the Brazilian savanna. Tropical Fire Ecology: Climate Change, Land Use, and Ecosystem Dynamics (ed. M.A. Cochrane), pp. 427-450. Springer and Praxis Publishing Ltd, Chichester, UK.

Mistry, J. (1998) Fire in the Cerrado (savannas) of Brazil: an ecological review. Progress in Physical Geography, 22, 425-448.

Mittermeier, R.A., Myers, N., Thomsen, J.B., da Fonseca, G.A.B. \& Olivieri, S. (1998) Biodiversity hotspots and major tropical wilderness areas: approaches to setting conservation priorities. Conservation Biology, 12, 516-520.

Moreira, A.G. (2000) Effects of fire protection on savanna structure in central Brazil. Journal of Biogeography, 27, 1021-1029.

Myers, N., Mittermeier, R.A., Mittermeier, C.G., da Fonseca, G.A.B. \& Kent, J. (2000) Biodiversity hotspots for conservation priorities. Nature, 403, 853-858.

Naya, D.E., Veloso, C., Munoz, J.L. \& Bozinovic, F. (2007) Some vaguely explored (but not trivial) costs of tail autotomy in lizards. Comparative Biochemistry and Physiology A, 146, 189-193. 
Niewiarowski, P.H., Congdon, J.D., Dunham, A.E., Vitt, L.J. \& Tinkle, D.W. (1997) Tales of lizard tails effects of tail autotomy on subsequent survival and growth of free-ranging hatchling. Canadian Journal of Zoology, 75, 542-548.

Nimer, E. (1989) Climatologia do Brasil. IBGE, Departamento de Recursos Naturais e Estudos Ambientais, Rio de Janeiro.

Nimmo, D.G., Kelly, L.T., Spence-Bailey, L.M., Watson, S.J., Taylor, R.S., Clarke, M.F. \& Bennett, A.F. (2013) Fire mosaics and reptile conservation in a fire-prone region. Conserv Biol, 27, 345-353.

Nogueira, C., Colli, G.R. \& Martins, M. (2009) Local richness and distribution of the lizard fauna in natural habitat mosaics of the brazilian Cerrado. Austral Ecology, 34, 83-96.

Ogutu, J.O., Piepho, H.P., Dublin, H.T., Bhola, N. \& Reid, R.S. (2008) Rainfall influences on ungulate population abundance in the Mara-Serengeti ecosystem. Journal of Animal Ecology, 77, 814-829.

Oliveira-Filho, A.T. \& Ratter, J.A. (2002) Vegetation physiognomies and woody flora of the Cerrado biome. The Cerrados of Brazil: Ecology and Natural History of a Neotropical Savanna (eds P.S. Oliveira \& R.J. Marquis), pp. 91-120. Columbia University Press, New York.

Oliveira, P.S. \& Marquis, R.J. (2002) The Cerrados of Brazil. Ecology and Natural History of a Neotropical Savanna. Columbia University Press, New York.

Pafilis, P., Foufopoulos, J., Poulakakis, N., Lymberakis, P. \& Valakos, E.D. (2009) Tail shedding in island lizards [Lacertidae, Reptilia]: decline of antipredator defenses in relaxed predation environments. Evolution, 63, 1262-1278.

Pantoja, D.L. (2007a) Efeitos do fogo sobre a taxocenose de lagartos em áreas de cerrado sensu stricto no Brasil Central. Master, Universidade de Brasília.

Pantoja, D.L.L. (2007b) Efeitos do fogo sobre a taxocenose de lagartos em áreas de Cerrado. Master in Animal Biology Master's Dissertation, Universidade de Brasília.

Passos, D.C., Galdino, C.A.B., Bezerra, C.H. \& Zanchi, D. (2013) Indirect evidence of predation and intraspecific agression in three sympatric lizard species from a semi-arid area in northeastern Brazil. Zoologia (Curitiba), 30, 467-469.

Pastro, L.A., Dickman, C.R. \& Letnic, M. (2014) Fire type and hemisphere determine the effects of fire on the alpha and beta diversity of vertebrates: a global meta-analysis. Global Ecology and Biogeography, 23, 1146-1156.

Peig, J. \& Green, A.J. (2009) New perspectives for estimating body condition from mass/length data: the scaled mass index as an alternative method. Oikos, 118, 1883-1891.

Peig, J. \& Green, A.J. (2010) The paradigm of body condition: a critical reappraisal of current methods based on mass and length. Functional Ecology, 24, 1323-1332.

Pianka, E.R. (1996) Long-term changes in lizards assemblages in the Great Victoria Desert: dynamic habitat mosaics in response to wildfires. Long-term studies of vertebrate communities (eds M.L. Cody \& J.A. Smallwood), pp. 191-215. San Diego: Academic Press.

Pianka, E.R. \& Huey, R.B. (1978) Comparative ecology, resource utilization and niche segregation among gekkonid lizards in the southern Kalahari. Copeia, 1978, 691-701.

Pianka, E.R. \& Pianka, H.D. (1976) Comparative ecolgy of twelve species of noctural lizards in the western Australian desert. Copeia, 1976, 125-142.

Pinheiro, F., Diniz, I.R., Coelho, D. \& Bandeira, M.P.S. (2002) Seasonal pattern of insect abundance in the Brazilian Cerrado. Austral Ecology, 27, 132-136.

Pinto, A.C.S., Wiederhecker, H.C. \& Colli, G.R. (2005) Sexual dimorphism in the Neotropical lizard Tropidurus torquatus (Squamata, Tropiduridae). Amphibia-Reptilia, 26, 127-137. 
Pivello, V.R. (2011) The Use of Fire in the Cerrado and Amazonian Rainforests of Brazil: Past and Present. Fire Ecology, 7, 24-39.

Pivello, V.R., Oliveras, I., Miranda, H.S., Haridasan, M., Sato, M.N. \& Meirelles, S.T. (2010) Effect of fires on soil nutrient availability in an open savanna in Central Brazil. Plant and Soil, 337, 111-123.

Pleguezuelos, J.M., Feriche, M. \& Santos, X. (2013) Tail-breakage effects on snake-body condition. Zoologischer Anzeiger, 252, 243-245.

Prada, M., Marini-Filho, O.J. \& Price, P.W. (1995) Insects in flower heads of Aspilla foliacea (Asteraceae) after a fire in a central brazilian savanna: evidence for the plant vigor hypothesis. Biotropica, 27, 513-518.

Prevedello, J.A., Dickman, C.R., Vieira, M.V. \& Vieira, E.M. (2013) Population responses of small mammals to food supply and predators: a global meta-analysis. Journal of Animal Ecology, 82, 927-936.

R Core Team (2015) R: a language and environment for statistical computing. R Foundation for Statistical Computing, Vienna, Austria.

Radford, I.J. \& Andersen, A.N. (2012) Effects of fire on grass-layer savanna macroinvertebrates as key food resources for insectivorous vertebrates in northern Australia. Austral Ecology, 37, 733-742.

Ramos-Neto, M.B. \& Pivello, V.R. (2000) Lightning fires in a Brazilian savanna National Park: Rethinking management strategies. Environmental Management, 26, 675-684.

Ramos, A.M., dos Santos, L.A.R. \& Fortes, L.T.G. (2009) Normais Climatológicas do Brasil 19611990. INMET, Brasília, DF. (ed. INMET). Brasília, DF.

Read, J.L., Kovac, K.-J., Brook, B.W. \& Fordham, D.A. (2012) Booming during a bust: Asynchronous population responses of arid zone lizards to climatic variables. Acta Oecologica, 40, 51-61.

Reed, T.E., Waples, R.S., Schindler, D.E., Hard, J.J. \& Kinnison, M.T. (2010) Phenotypic plasticity and population viability: the importance of environmental predictability. Proceedings of the Royal Society, 277, 3391-3400.

Ribeiro, J.F. \& Walter, B.M.T. (1998) Fitofisionomias do bioma Cerrado. Cerrado: Ambiente e Flora (eds S.M. Sano \& S.P. Almeida), pp. 89-166. EMBRAPA, Planaltina.

Ribeiro, M.L. (2011) Reserva Ecológica do IBGE: Biodiversidade Terrestre. IBGE, Rio de Janeiro.

Rocha, C.F.D., Van Sluys, M., Vrcibradic, D., Kiefer, M.C., Menezes, V.A. \& Siqueira, C.d.C. (2009) Comportamento de termorregulação em lagartos brasileiros. Oecologia Brasileira, 13, 115-131.

Rodrigues, M.T. (1987) Sistemática, ecologia e zoogeografia dos Tropidurus do grupo torquatus ao sul do rio Amazonas (Sauria, Iguanidae). Arquivos de Zoologia, 31, 105-230.

Rojas-González, I., Jones, C.P., Zuñiga-Vega, J.J. \& Lemos-Espinal, J. (2008) Demography of Xenosaurus platyceps (Squamata: Xenosauridae) a comparison between tropical and temperate populations. Amphibia-Reptilia, 29, 245-256.

Rubin, D.B. (1996) Multiple imputation after 18+ years. Journal of the American Statistical Association, 91, 473-489.

Russell, A.P., Lynn, S.E., Powell, G.L. \& Cottle, A. (2015) The regenerated tail of juvenile leopard geckos (Gekkota: Eublepharidae: Eublepharis macularius) preferentially stores more fat than the original. Zoology (Jena).

Russell, K.R., Lear, D.H.V. \& Guynn Jr., D.C. (1999) Prescribed fire effects on herpetofauna: review and management implications. Wildlife Society Bulletin, 27, 374-384. 
Salvador, A. \& López, P. (1995) Tail loss reduces home range size and access to females in male lizards, Psammodromus algirus. Behavioral Ecology, 6, 382-387.

Salvador, A. \& Veiga, J.P. (2005) Activity, tail loss, growth and survivorship of male Psammodromus algirus. Amphibia-Reptilia, 26, 583-585.

Samia, D.S., Blumstein, D.T., Stankowich, T. \& Cooper, W.E., Jr. (2015) Fifty years of chasing lizards: new insights advance optimal escape theory. Biological Reviews.

Schall, J.J. \& Pianka, E.R. (1980) Evolution of escape behavior diversity. American Naturalist, 115, 551-566.

Schoener, T.W. (1979) Inferring the properties of predation and other injury-producing agents from injury frequencies. Ecology, 60, 1110-1115.

Schoener, T.W. \& Schoener, A. (1980) Ecological and demographic correlates of injury rates in some bahamian Anolis lizards. Copeia, 1980, 839-850.

Schwarkzopf, L. \& Shine, R. (1992) Costs of reproduction in lizards escape tactics and susceptibility to predation. Behavioral Ecology and Sociobiology, 31, 17-25.

Shepard, D.B. (2007a) Habitat but not body shape affects predator attack frequency on lizard models in the brazilian Cerrado. Journal of Herpetology, 63, 193-202.

Shepard, D.B. (2007b) Habitat but not body shape affects predator attack frequency on lizard models in the Brazilian Cerrado. Herpetologica, 63, 193-202.

Shine, R. (2005) Life-history evolution in reptiles. Annual Review of Ecology, Evolution, and Systematics, 36, 23-46.

Shine, R. \& Schwarzkopf, L. (1992) The evolution of reproductive effort in lizards and snakes. Evolution, 46, 62-75.

Silva, V.d.N., Pressey, R.L., Machado, R.B., VanDerWal, J., Wiederhecker, H.C., Werneck, F.P. \& Colli, G.R. (2014) Formulating conservation targets for a gap analysis of endemic lizards in a biodiversity hotspot. Biological Conservation, 180, 1-10.

Simon, M.F., Grether, R., de Queiroz, L.P., Skema, C., Pennington, R.T. \& Hughes, C.E. (2009) Recent assembly of the Cerrado, a neotropical plant diversity hotspot, by in situ evolution of adaptations to fire. Proceedings of the National Academy of Sciences of the United States of America, 106, 20359-20364.

Sinervo, B., Mendez-de-la-Cruz, F., Miles, D.B., Heulin, B., Bastiaans, E., Villagran-Santa Cruz, M., Lara-Resendiz, R., Martinez-Mendez, N., Calderon-Espinosa, M.L., Meza-Lazaro, R.N., Gadsden, H., Avila, L.J., Morando, M., De la Riva, I.J., Victoriano Sepulveda, P., Rocha, C.F., Ibarguengoytia, N., Aguilar Puntriano, C., Massot, M., Lepetz, V., Oksanen, T.A., Chapple, D.G., Bauer, A.M., Branch, W.R., Clobert, J. \& Sites, J.W., Jr. (2010) Erosion of lizard diversity by climate change and altered thermal niches. Science, 328, 894899.

Smith, A.L., Bull, C.M. \& Driscoll, D.A. (2012) Post-fire succession affects abundance and survival but not detectability in a knob-tailed gecko. Biological Conservation, 145, 139147.

Smith, A.L., Michael Bull, C. \& Driscoll, D.A. (2013) Successional specialization in a reptile community cautions against widespread planned burning and complete fire suppression. Journal of Applied Ecology, 50, 1178-1186.

Sousa, H.C., Soares, A.H.B., Costa, B.M., Pantoja, D.L., Caetano, G.H., Queiroz, T.A. \& Colli, G.R. (submitted) Fire regimes and the demography of an endemic lizard in a savanna biodiversity hotspot. South American Journal of Herpetology.

Sousa, H.C.d., Soares, A.H.S.B., Costa, B.M., Pantoja, D.L., Caetano, G.H., Queiroz, T.A.d. \& Colli, G.R. (2015) Fire regimes and the demography of the lizard Micrablepharus atticolus 
(Squamata, Gymnophthalmidae) in a biodiversity hotspot. South American Journal of Herpetology, 10, 143-156.

Stamps, J. \& Tanaka, S. (1981) The influence of food and water on growth rates in a tropical lizard (Anolis aeneus). Ecology, 62, 1981.

Stawski, C., Matthews, J.K., Kortner, G. \& Geiser, F. (2015) Physiological and behavioural responses of a small heterothermic mammal to fire stimuli. Physiology \& Behavior, 151, 617-622.

Stearns, S.C. (1977) The evolution of life history traits: a critique of the theory and a review of the data. Annual Review of Ecology and Systematics, 8, 145-171.

Steffen, W., Grinevald, J., Crutzen, P. \& McNeill, J. (2011) The Anthropocene: conceptual and historical perspectives. Philos Trans A Math Phys Eng Sci, 369, 842-867.

Stubben, C. \& Milligan, B. (2007) Estimating and analyzing demographic models using the popbio package in R. Journal of Statistical Software, 22, 1-23.

Stubben, C., Milligan, B. \& Nantel, P. (2012) Construction and analysis of matrix population models.

Sun, Y.Y., Yang, J. \& Ji, X. (2009) Many-lined sun skinks (Mabuya multifasciata) do not compensate for the costs of tail loss by increasing feeding rate or digestive efficiency. $J$ Exp Zool A Ecol Genet Physiol, 311, 125-133.

Tanner, D. \& Perry, J. (2007) Road effects on abundance and fitness of Galapagos lava lizards (Microlophus albemarlensis). J Environ Manage, 85, 270-278.

Telemeco, R.S., Radder, R.S., Baird, T.A. \& Shine, R. (2010) Thermal effects on reptile reproduction: adaptation and phenotipic plasticity in a montane lizard. Biological Journal of the Linnean Society, 100, 642-655.

Templeton, A.R., Brazeal, H. \& Neuwald, J.L. (2011) The transition from isolated patches to a metapopulation in the eastern collared lizard in response to prescribed fires. Ecology, 92, 1736-1747.

Tinkle, D.W. (1967) The life and demography of the side-blotched lizard, Uta stansburiana. Miscellaneous publications from the Museus of Zoology, University of Michigan, 1967, 1182.

Tsasi, G., Pafilis, P., Simou, C. \& Valakos, E.D. (2009) Predation pressure, density-induced stress and tail regeneration: a casual-nexus situation or a bunch of independ factors? AmphibiaReptilia, 30, 471-482.

Uehara-Prado, M., Bello, A.d.M., Fernandes, J.d.O., Santos, A.J., Silva, I.A. \& Cianciaruso, M.V. (2010) Abundance of epigaeic arthropods in a Brazilian savanna under different fire frequencies. Zoologia (Curitiba, Impresso), 27, 718-724.

Ujvari, B., Fisher, P., Rydell, J., Wahlgren, R., Wright, B. \& Madsen, T. (2015) Population demography of frillneck lizards (Chlamydosaurus kingii, Gray 1825) in the wet-dry tropics of Australia. Austral Ecology, 40, 60-66.

Van Sluys, M. (1993a) Food habits of the lizard Tropidurus itambere (Tropiduridae) in southeastern Brazil. Journal of Herpetology, 27, 347-351.

Van Sluys, M. (1993b) The reproductive cycle of Tropidurus itambere (Sauria Tropiduridae) in southeastern Brazil. Journal of Herpetology, 27, 28-32.

Van Sluys, M. (1997) Home range of the saxicolous lizard Tropidurus itambere (Tropiduridae) in southeastern Brazil. Copeia, 1997, 623-628.

Van Sluys, M. (1998) Growth and body condition of the saxicolous lizard Tropidurus itambere in southeastern Brazil. Journal of Herpetology, 32, 359-365. 
Van Sluys, M. (2000) Population dynamics of the saxicolous lizard Tropidurus itambere (Tropiduridae) in a seasonal habitat of southeastern Brazil. Herpetologica, 56, 55-62.

Van Sluys, M., Vrcibradic, D. \& Rocha, C.F.D. (2002) Tais loss in the syntopic lizards Tropidurus itambere (Tropiduridae) and Mabuya frenata (Scincidae) in southeastern Brazil. Studies on Neotropical Fauna and Environment, 37, 227-231.

Vieira, E.M., Andrade, I. \& Price, P.W. (1996) Fire effects on a Palicourea rigida (Rubiaceae) gall midge: a test of the plant vigor hypothesis. Biotropica, 28, 210-217.

Vitt, L.J. (1981) Tail autotomy and regeneration in the tropical skink, Mabuya heathi. Journal of Herpetology, 15, 454-457.

Vitt, L.J. (1983) Tail loss in lizards: the significance of foraging and predator escape modes. Herpetologica, 39, 151-162.

Vitt, L.J., Congdon, J.D. \& Dickson, N.A. (1977) Adaptive strategies and energetics of tail autonomy in lizards. Ecology, 58, 326-337.

Vitt, L.J. \& Cooper, W.E., Jr. (1986) Tail loss, tail color, and predator escape in Eumeces (Lacertilia Scincidae): age-specific differences in costs and benefits. Canadian Journal of Zoology, 64, 583-592.

Warner, D.A. \& Shine, R. (2007) Fitness of juvenile lizards depends on seasonal timing of hatching, not offspring body size. Oecologia, 154, 65-73.

Warton, D.I., Wright, I.J., Falster, D.S. \& Westoby, M. (2006) Bivariate line-fitting methods for allometry. Biological Reviews, 81, 259-291.

Watson, S.J., Taylor, R.S., Nimmo, D.G., Kelly, L.T., Clarke, M.F., Bennett, A.F., Gordon, I. \& Evans, D. (2012a) The influence of unburnt patches and distance from refuges on post-fire bird communities. Animal Conservation, 15, 499-507.

Watson, S.J., Taylor, R.S., Nimmo, D.G., Kelly, L.T., Haslem, A., Clarke, M.F. \& Bennett, A.F. (2012b) Effects of time-since-fire on birds: how informative are generalized fire-response curves for conservation management? Ecological Applications, 22, 685-696.

Watson, S.J., Taylor, R.S., Spence-Bailey, L., Nimmo, D.G., Kenny, S., Kelly, L.T., Haslem, A., Griffioen, P., Callister, K., Brown, L., Avitabile, S., Bennett, A. \& Clarke, M.F. (2012c) The Mallee fire and biodiversity project. Proceedings of the Royal Society of Victoria, 124, 38-46.

Webb, J.K. (2006) Effects of tail autotomy on survival, growth and territory occupation in freeranging juvenile geckos (Oedura lesueurii). Austral Ecology, 31, 432-440.

White, G.C. \& Burnham, K.P. (1999) Program MARK: survival estimation from populations of marked animals. Bird Study, 46, 120-139.

White, T.C.R. (2013) Experimental and observational evidence reveals that predators in natural environments do not regulate their prey: They are passengers, not drivers. Acta Oecologica, 53, 73-87.

Wilgers, D.J. \& Horne, E.A. (2007a) Spatial variation in predation attempts on artificial snakes in a fire-disturbed tallgrass prairie. The Southwestern Naturalist, 52, 263-270.

Wilgers, D.J. \& Horne, E.A. (2007b) Spatial variation in predation attempts on artificial snakes in a fire-disturbed tallgrass prairie. The Southwestern Naturalist, 52, 263-270.

Wilson, B.S. (1992) Tail injuries increase the risk of mortality in free-living lizards (Uta stansburiana). Oecologia, 92, 145-152.

Wilson, B.S. \& Cooke, D.E. (2004) Latitudinal variation in rates of overwinter mortality in the lizard Uta stansburiana. Ecology, 85, 3406-3417.

Wilson, R.S. \& Booth, D.T. (1998) Effect of tail loss on reproductive output and its ecological significance in the skink Eulamprus quoyii. Journal of Herpetology, 32, 128-131. 
Wood, S.N. (2004) Stable and efficient multiple smoothing parameter estimation for generalized additive models. Journal of the American Statistical Association, 99, 673-686.

Zalasiewicz, J., Williams, M., Haywood, A. \& Ellis, M. (2011) The Anthropocene: a new epoch of geological time? Philos Trans A Math Phys Eng Sci, 369, 835-841.

Zani, P.A. (1996) Patterns of caudal-autotomy evolution in lizards. Journal of Zoology, 240, 201220.

Zar, J.H. (2010) Biostatistical Analysis. Prentice Hall, Inc., Upper Saddle River, New Jersey.

Zhang, P. (2003) Multiple imputation: theory and method. International Statistical Review, 71, 581-592. 

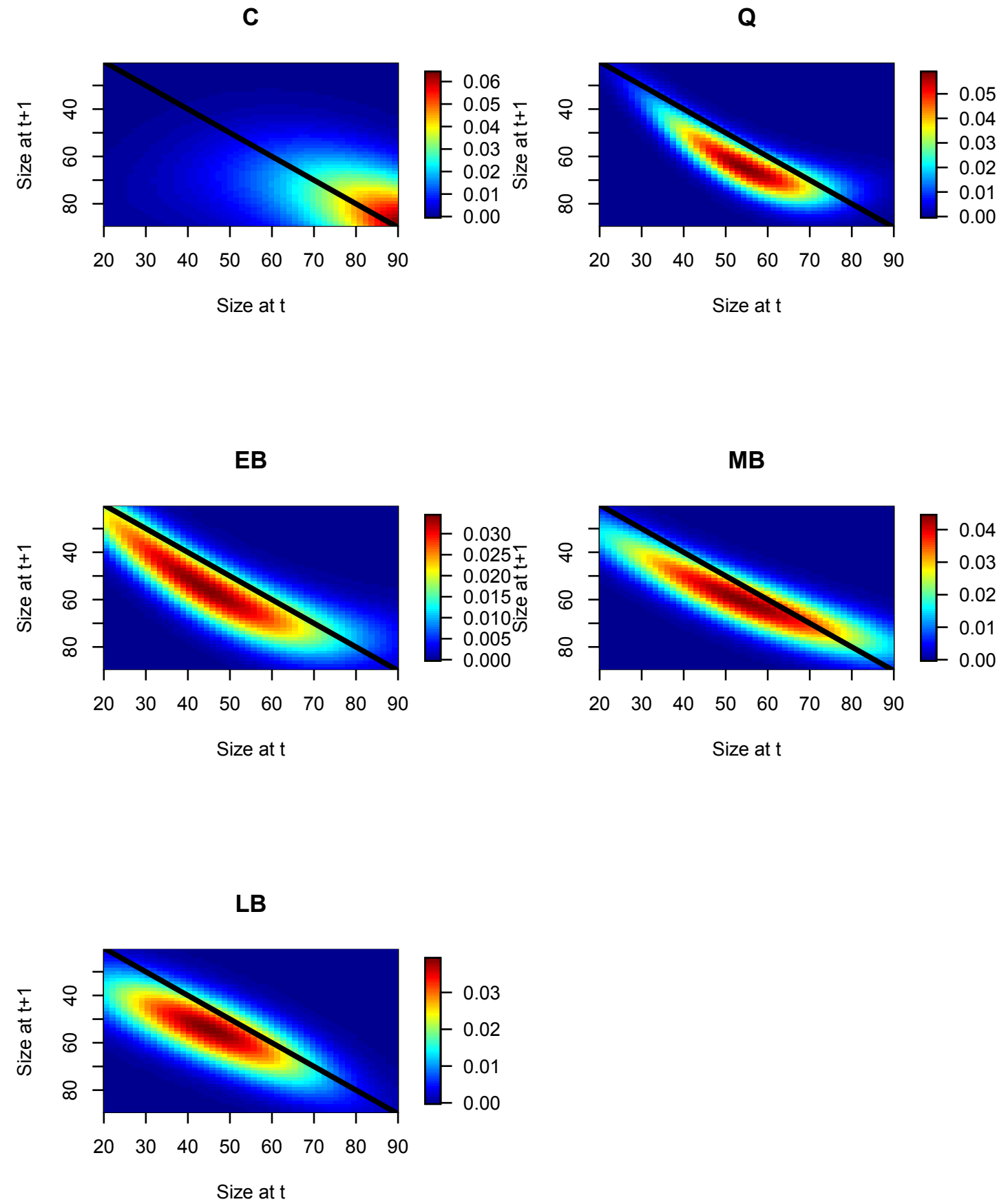

Figure S1. Probability of survival/growth kernels from Tropidurus itambere made to produce integral projection models in five experimental plots submitted to different burn regimes at Reserva Ecológica do IBGE, Brasília, Distrito Federal, Brazil. The dashed line indicates stasis, individuals that fall above this line neither grow nor shrink. 
C

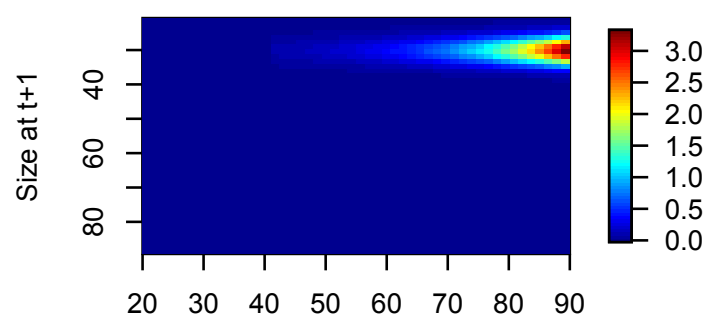

Size at $\mathrm{t}$

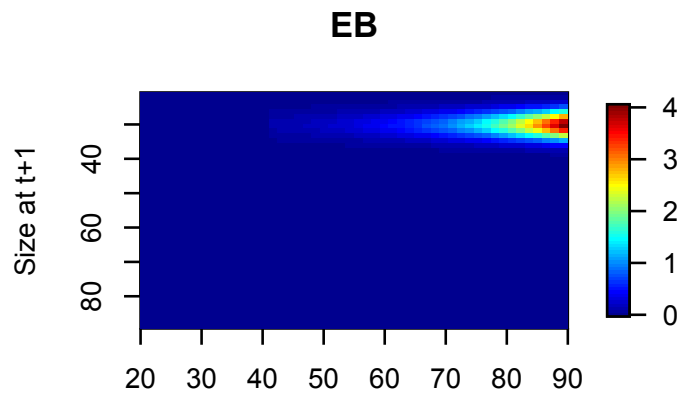

Size at $\mathrm{t}$

LB

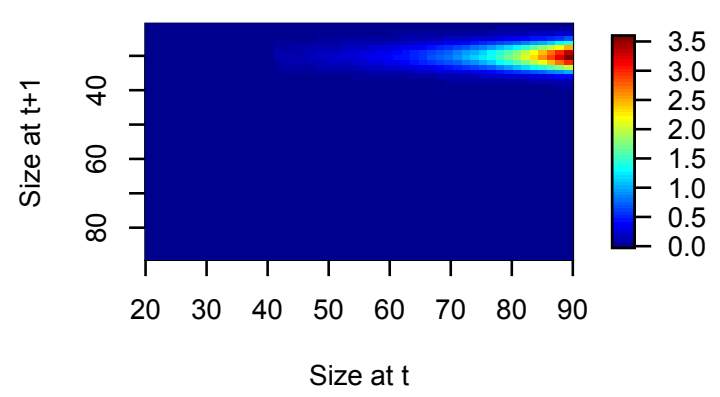

Q

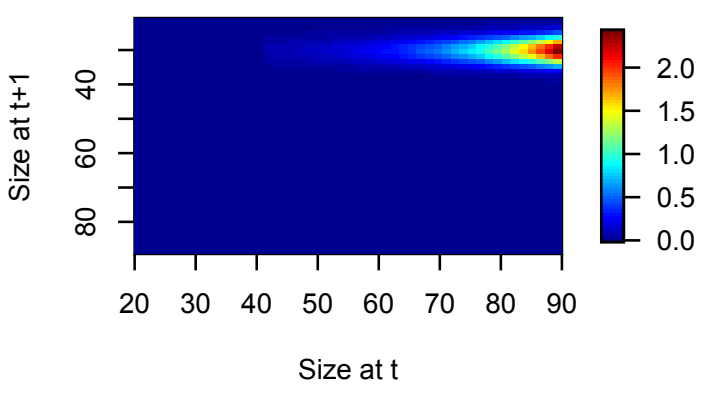

MB

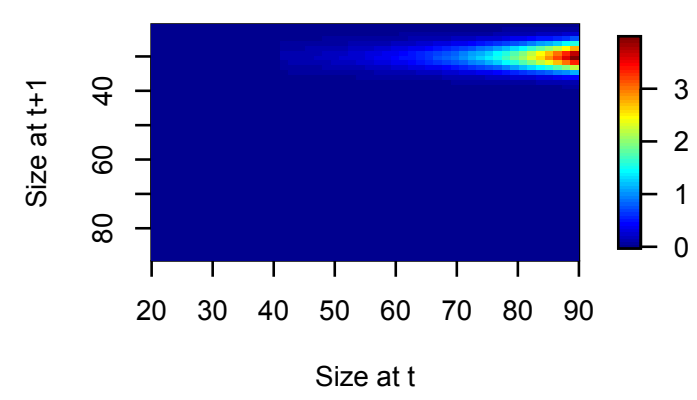

Figure S2. Fecundity kernels from Tropidurus itambere made to produce integral projection models in five experimental plots submitted to different burn regimes at Reserva Ecológica do IBGE, Brasília, Distrito Federal, Brazil. Fecundity function included clutch size, normal distribution size of hatchlings and probability of establishment of the eggs. 

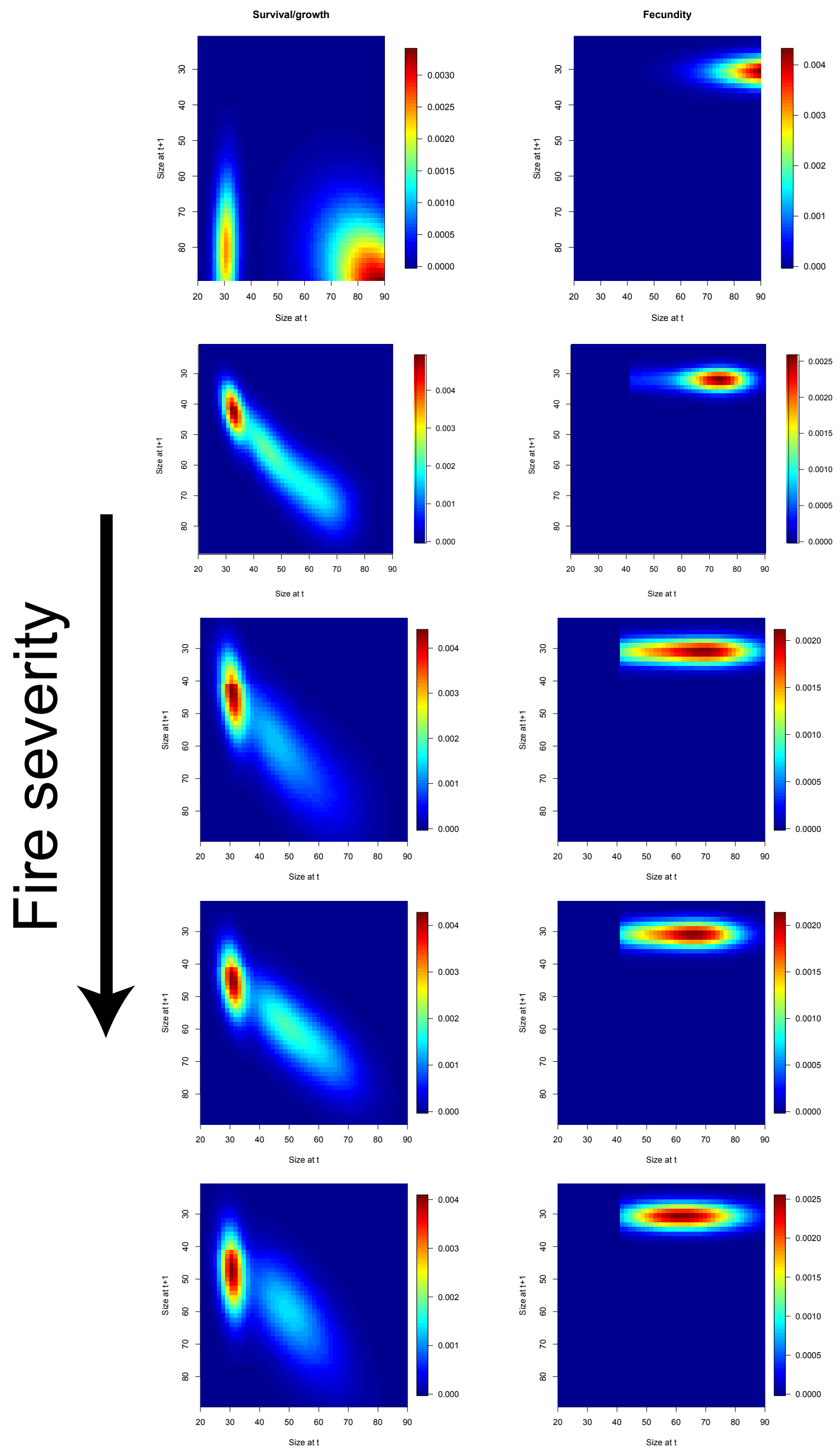

Figure S3. Long-term population growth rate elasticity matrixes split into contributions made by the survival/growth (left column) and fecundity (right column) kernels from Tropidurus itambere in cerrado sensu stricto control and treatment plots of varying fire severity, in central Brazil. First line: control; $2^{\circ}$ line: quadrennial; $3^{\circ}$ line: early biennial; $4^{\circ}$ line: mid biennial; $5^{\circ}$ line: late biennial. 


\section{Capítulo 4: Autotomia caudal em um lagarto de uma savana Neotropical (Tropidurus itambere): padrões, custos e adaptabilidade}

A autotomia caudal é uma adaptação antipredatória extrema entre os lagartos, que é mantida somente se os benefícios superarem os custos. Nós investigamos os custos e a adaptabilidade da autotomia caudal como uma estratégia antipredatória no lagarto endêmico do Cerrado, Tropidurus itambere, em um estudo em longo prazo de marcação e recaptura. A condição corporal, sobrevivência e o crescimento corporal foram comparados entre indivíduos com e sem caudas para procurar por custos potenciais da autotomia. Nós contrastamos as frequências de autotomia caudal usando abertura do hábitat, sexo, ontogenia e estações como fatores. Nós também analisamos a regeneração de cauda ao longo da ontogenia para procurar por tradeoffs na alocação de energia. Os custos de sobrevivência, crescimento e condição corporal relacionados à autotomia caudal em $T$. itambere são baixos, exceto em machos, os quais tiveram sua sobrevivência reduzida após a perda das caudas. As frequências de autotomia caudal e sobrevivência não variaram com a abertura do hábitat, indicando provável compensação comportamental. Adicionalmente, a baixa frequência de autotomia caudal na espécie $(9 \%)$ sugere que os indivíduos provavelmente se valem de outros mecanismos para evitar a predação (como a camuflagem), e que a pressão de predação deve ser baixa. Além disso, a regeneração da cauda foi mais rápida em sub-adultos do que em jovens e adultos maduros, o que sugere que a presença da cauda é mais importante no começo da maturidade do que em qualquer outro período de vida, provavelmente devido às interações reprodutivas. A autotomia caudal parece ser uma adaptação mais importante para adultos do que jovens em $T$. itambere, especialmente em machos, que precisam se esforçar em interações sociais agressivas, 
por consequência se expondo mais a predadores. Este estudo traz perspectivas integradas sobre a autotomia caudal como uma adaptação antipredatória em lagartos. 
Tail autotomy in a Neotropical savannah lizard: patterns, costs and adaptability

Heitor C. de Sousa ${ }^{1}$, Bernardo M. Costa ${ }^{2}$, Carlos José S. Morais ${ }^{1}$, Davi L. Pantoja ${ }^{1}$, Helga C. Wiederhecker ${ }^{1}$, Guarino R. Colli ${ }^{1}$

1 Departamento de Zoologia, Universidade de Brasília, 70910-900 Brasília, DF, Brasil

2 Instituto Federal de Brasília, Campus Gama, Lote 01, DF 480, Setor de múltiplas Atividades, 72429-005, Gama, DF, Brasil

Correspondence: Heitor C. de Sousa, Departamento de Zoologia, Universidade de Brasília, 70910-900 Brasília, DF, Brasil. E-mail: heitorsousa.bio@gmail.com 


\section{Abstract}

Tail autotomy is an extreme antipredator adaptation among lizards that is only maintained in the species if benefits exceed costs. We investigated the costs and adaptability of tail autotomy as an antipredator strategy in the endemic Cerrado lizard (Tropidurus itambere) in a long-term mark and recapture study. Body condition, survival, and body growth were compared between tailed and tailless individuals to seek for potential costs of autotomy. We contrasted caudal autotomy frequencies using habitat openness, between sexes, along ontogeny and seasons as factors. We analyzed tail regeneration along the ontogeny to seek for tradeoffs in energy allocation. The costs of survival, body growth and condition in T. itambere are low, except in males, which had their survival reduced after tail loss. Tail autotomy frequencies and survival did not vary with the habitat openness, indicating that detection of the prey is an important factor involved in predation, probably because of behavior compensations. Additionally, the low frequency of autotomy in the species $(9 \%)$ reveals that the individuals rely rather in crypsis than in autotomy to avoid predation, and that predation pressure might be very low. Moreover, tail regeneration was higher in early adults than juveniles or late adults, suggesting that tail presence is more important during the early maturity than in any other period of life, probably related to reproductive-time interactions. Tail autotomy seems to be an adaptation more important to adults than in juveniles of $T$. itambere, especially in males, which need to struggle in aggressive social interactions, wherefore they end up more exposed to predators. This study brings integrative perspectives upon the tail autotomy as an antipredator adaptation in lizards.

Keywords: Survival; Body condition; Growth; Cerrado; Tail loss 


\section{Introduction}

Predation pressure is an important factor that affects directly individuals' fitness. It shapes behavioral, ecological, morphological and physiological traits of the animals, and led to extreme escape tactics, as the tail autotomy in lizards (Arnold 1987; Bateman \& Fleming 2009). This adaptation seems to be plesiomorphic in Squamata and was lost several times in the clade (Arnold 1984). An autotomizable tail increases the chances of surviving to a predation attempt (Congdon, Vitt \& King 1974; Vitt, Congdon \& Dickson 1977; Vitt \& Cooper 1986). However, the evolutive maintenance of this strategy in specific lineages depends on the tradeoffs between costs and benefits following the autotomy event (Vitt, Congdon \& Dickson 1977; Arnold 1984; Arnold 1987).

The tail loss per se implies physiological costs to a lizard because it may lose important energetic reserves (Congdon, Vitt \& King 1974; Vitt, Congdon \& Dickson 1977; Dial \& Fitzpatrick 1981; Vitt 1981; Wilson \& Booth 1998; Langkilde, Alford \& Schwarkzopf 2005; Lin, Qu \& Ji 2006; Sun, Yang \& Ji 2009; Boozalis, LaSalle \& Davis 2012; Lu et al. 2012; Russell et al. 2015) and may to require increase metabolism to regenerate the lost appendage (Dial \& Fitzpatrick 1981; Chapple \& Swain 2002; Naya et al. 2007). Besides, the tailless animals will probably be more susceptible to predation, since they do not have the tail to use in future predation attempts (Congdon, Vitt \& King 1974; Vitt, Congdon \& Dickson 1977; Daniels, Flaherty \& Simbotwe 1986; Vitt \& Cooper 1986; Medel et al. 1988; Downes \& Shine 2001; Langkilde, Alford \& Schwarkzopf 2005). In addition to these intrinsic costs, the autotomy may have secondary costs related to locomotion and behavior. Several studies report reduction in speed and stride length (Ballinger, Nietfeldt \& Krupa 1979; Anderson et al. 2012; Cromie \& Chapple 2012; Lu, Ji \& Du 2013; McElroy \& Bergmann 2013) with consequent effects on the species behavior (Martin \& Salvador 
1992; Martin \& Salvador 1993a; Martin \& Salvador 1993b; Martin \& Salvador 1993c; Salvador \& López 1995; Martin \& Salvador 1997; Salvador \& Veiga 2005). Behavior changes documented after tail loss also include reduction of social status (Fox, Rose \& Myers 1981; Fox \& Rostker 1982; Fox, Heger \& Delay 1990; Martin \& Salvador 1993b), microhabitat selection (Martin \& Salvador 1992; Martin \& Salvador 1997; Downes \& Shine 2001), movements (Martin \& Salvador 1997), thermoregulation (Martin \& Salvador 1993c), food intake (Salvador \& López 1995), activity (McConnachie \& Whiting 2003; Salvador \& Veiga 2005), foraging (Martin \& Salvador 1993a; Cooper 2003), and escape tactics (Cooper 1998; Downes \& Shine 2001; Cooper 2003; Cooper 2007; Cooper \& Wilson 2010; Domínguez-López, Ortega-león \& Zamora-abrego 2015). These possible costs may affect individual life history characteristics such as survival probability (Wilson 1992; Niewiarowski et al. 1997; Fox \& McCoy 2000; Webb 2006), growth rate (Niewiarowski et al. 1997; Salvador \& Veiga 2005; Webb 2006; Iraeta, Salvador \& Díaz 2012; Russell et al. 2015), and reproductive output (Dial \& Fitzpatrick 1981; Wilson \& Booth 1998; Chapple, McCoull \& Swain 2002; Lu et al. 2012), which in turn affect the individual fitness. However, studies relating caudal autotomy to life history traits are concentrated in few species under unnatural conditions, which are often not able to mimic the environmental and ecological factors involved after the tail loss (Wilson 1992; Webb 2006).

The effects of tail loss on individual survival and growth in the field are very variable, both within and between lizard species (Fox \& McCoy 2000). The costs depend on the amount of energy contained in the tail and the compensatory behaviors adopted after autotomy, which vary between sex and along ontogeny (Fox \& McCoy 2000), because the tradeoffs may be different among them. Environmental and ecological factors such as resource availability and predation pressure should also influence the outcomes (Althoff \& Thompson 1994; Niewiarowski et al. 1997). Compensatory 
mechanisms include high tail regeneration rates (Vitt, Congdon \& Dickson 1977), enhanced food intakes (Dial \& Fitzpatrick 1981), enhanced activity if predation pressures are low and energy requirements are high (Martin \& Salvador 1997), or decreased activity if the opposite is true (Cooper 2003; Cooper 2007; Cooper \& Wilson 2010; Cromie \& Chapple 2012).

The frequency of tail autotomy in lizard natural populations may be an important measure to explain the maintenance of this tactic (Chapple \& Swain 2004). For instance, under low predation pressure the ease to shed the tail decreases, which leads to low autotomy frequencies in natural populations (Pafilis et al. 2009). In such cases, the costs of the autotomy may supersede the benefits in some lizards (Pafilis et al. 2009). The frequencies of caudal autotomy in natural lizard populations were commonly used to estimate the predation intensity (Pianka \& Pianka 1976; Pianka \& Huey 1978; Schall \& Pianka 1980). However, predator inefficiency and survival rates might explain caudal autotomy frequency, better than predation intensity (Schoener 1979; Jaksic \& Fuentes 1980; Schoener \& Schoener 1980; Medel et al. 1988; Bateman \& Fleming 2011). These confounding factors highlight the importance of combining demographic estimates with the autotomy frequencies and knowledge about local potential predators to explain the evolutionary maintenance of autotomy (Schoener \& Schoener 1980; Chapple \& Swain 2004; Cooper, PrezMellado \& Vitt 2004; Bateman \& Fleming 2011).

The habitat openness may affect predation intensity and efficiency. For instance, lizard populations in structurally open habitats may have higher frequency of autotomy than in close habitats, responding to higher predation intensity and lower efficiency in the former (Pianka \& Huey 1978; Tanner \& Perry 2007). Besides, differences in tail loss frequencies between sexes are expected if they have sexual dimorphism and attain different social roles, which lead to differing costs (Arnold 1987; Bateman \& Fleming 2009). Behavioral differences between juveniles and 
adults, and the time in which an animal is exposed to predators may also cause variation in the autotomy frequency along the ontogeny (Vitt, Congdon \& Dickson 1977; Vitt \& Cooper 1986; Hawlena et al. 2006; Hawlena 2009). Moreover, the tail regeneration rate may be low for hatchlings, which need to allocate more energy to body growth than tail regeneration (Vitt, Congdon \& Dickson 1977). Alternatively, in some species, individuals that have low probability to survive to the next breeding season and that reproduce more than once in the same reproductive season, quickly regenerate tails because fitness may be enhanced with a longer tail (Vitt, Congdon \& Dickson 1977). In addition, predation intensity and conspecific interactions may vary seasonally (McMillan \& Irschick 2010; Sousa et al. submitted), thereby may affect the autotomy frequencies.

Herein, we aim to study the causes (exposure of predation, seasonality, sexual dimorphism and ontogeny) and costs (body condition and growth, and survival) of autotomy in Tropidurus itambere Rodrigues, 1987 (Tropiduridae). Tropidurus itambere is an endemic lizard from the Brazilian Cerrado savannahs (Rodrigues 1987), which feeds on several groups of arthropods, mostly ants and termites (Van Sluys 1993a). It is an ambush forager with cryptic coloration spotted and most of the times the individuals from this species are exposed in the sun and motionless (Faria $\&$ Araujo 2004). When approached, the most used escape tactic is to flight to a known refuge (Faria \& Araujo 2004). This species presents sexual dimorphism, with males being larger (Schall \& Pianka 1980; Van Sluys 1993b). Males and females have small home range sizes with little overlap, hence they potentially perform territoriality (Van Sluys 1997). This short-lived species (until 2.5 years) has seasonal reproduction and activity, with hatching at the rainy season (Van Sluys 1998; Van Sluys 2000).

We assessed the costs of tail autotomy in Tropidurus itambere by measuring allocation of energy reserves (using body condition as a surrogate); survival probability; and body growth rate. 
We hypothesize that tail loss and the size of the autotomized portion of the tail should decrease body condition, body growth, survival, and recapture (1) due to loss of stored energy, energy allocation to the tail regeneration and impaired locomotion; and (2) mainly in adults, due to energy allocation towards reproduction and social interactions. Further, we hypothesize that T. itambere would have higher frequencies of autotomized tails in (3) more exposed habitats; in (4) the reproductive season, when animals are more active; in (5) older individuals; and in (6) males, which are more prone to predators and conspecific aggressive interactions when approaching females and defending territory. We also hypothesize that (7) tail regeneration would be larger and faster in adults, because juveniles allocate proportionally more energy to body growth and less to tail regeneration than adults do.

\section{Materials and methods}

Study area and population monitoring

We conducted this study in Reserva Ecológica do IBGE - RECOR (1556'41' S e 4753'07” W), Brasília, Distrito Federal, Brazil, at the core of the Cerrado biome (Oliveira \& Marquis 2002; Ribeiro 2011). Climate is markedly seasonal, with a wet season from October to April, followed by a dry season from May to September. From 1972 to 1990, the RECOR was fully protected from fires. A long-term experiment was initiated in 1989 to evaluate the effects of different burn regimes upon animals and plants (Miranda 2010; Pivello et al. 2010; Miranda et al. 2011). The sampling area was divided into 10 ha plots, each submitted to a different burn regime, characterized by a combination of the timing (early, modal and late dry season) and frequency (biennial and quadrennial) of burns, including unburned plots. We selected five plots (Fig. 1) in an area of cerrado 


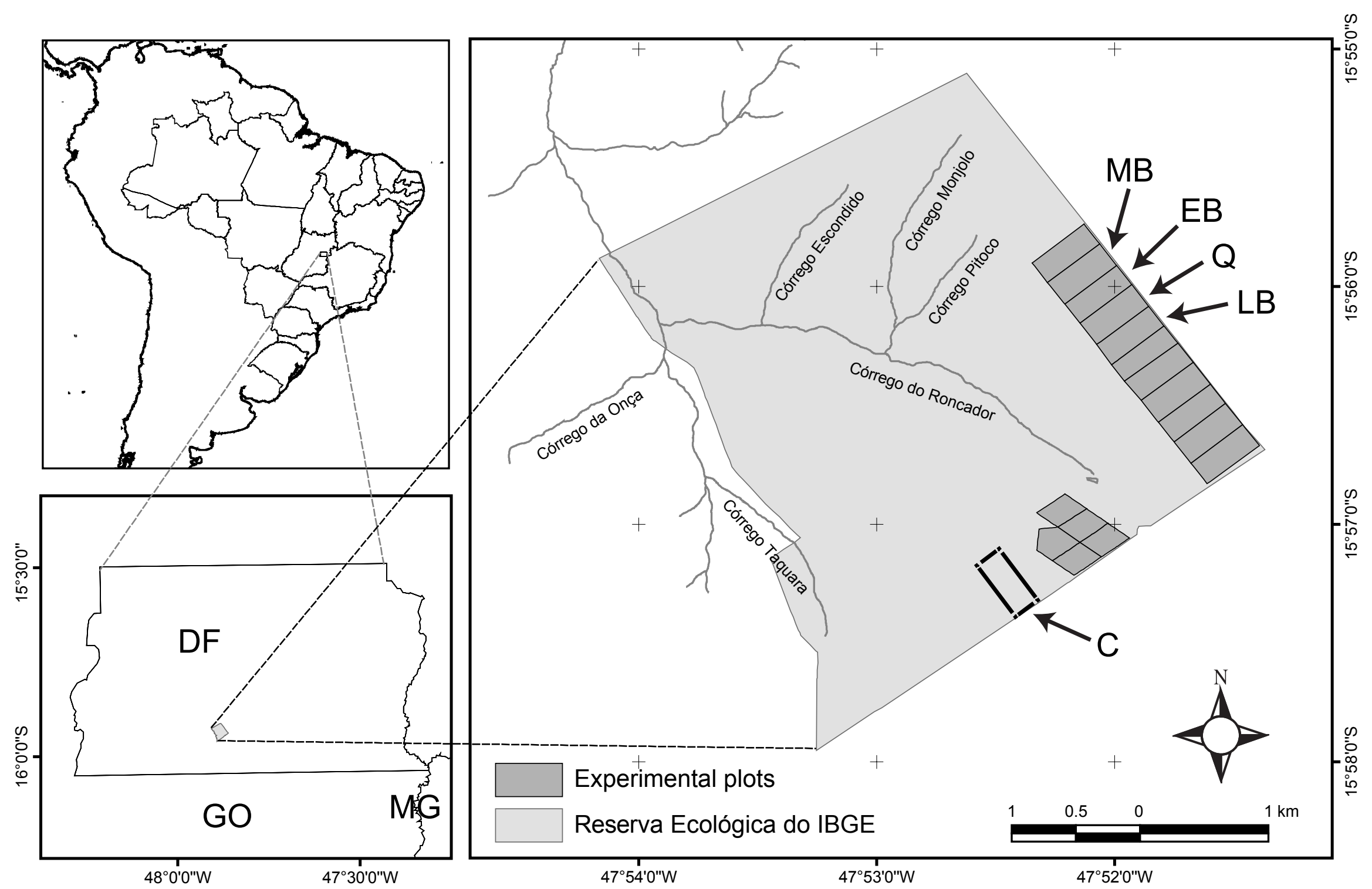

Fig. 1 Map with location of the studied plots: late biennial (LB), modal biennial (MB), early biennial (EB), quadrennial (Q) and the control without fire until 2011 (C). 
sensu stricto vegetation physiognomy (Oliveira-Filho \& Ratter 2002): three subjected to prescribed biennial burns (late biennial - LB, middle biennial - MB, and early biennial - EB), one subjected to quadrennial burns (middle quadrennial - Q), and one "control" plot (without fires - C). These treatments of burn regimes were presented as a gradient of disturbance, reflecting a gradient of habitat openness promoted by fire. The gradient vary from the densest woody-vegetation stands in plot $\mathrm{C}$ to the most open in plot LB, which is the least shaded plot (Pantoja 2007a; Costa 2011). Density of grass varies in the opposite way (Pantoja 2007a; Costa 2011). Therefore, fire severity and habitat openness in the experimental plots increased in this order: $\mathrm{C} \rightarrow \mathrm{Q} \rightarrow \mathrm{EB} \rightarrow \mathrm{MB} \rightarrow$ LB. We assumed that lizards inhabiting plots with increased habitat openness and reduced leaf litter are more exposed to predators and, as a consequence, should exhibit higher frequency of tail autotomy (Pianka \& Huey 1978; Tanner \& Perry 2007).

From Oct 2010 to Dec 2014, we monitored the five plots with pitfall traps with drift fences. Each trap consisted of four 301 buckets buried until ground level and arranged in a "Y" shape, interconnected by $6 \mathrm{~m}$ long metal drift fences. We installed ten traps in each plot and checked daily during six consecutive days every month. We recorded the following data of each captured lizard: snout-vent-length (SVL), tail length, and length of regenerated portion of tail (RTL, if any) with a ruler ( $1 \mathrm{~mm}$ precision); body mass, with a spring scale ( $0.1 \mathrm{~g}$ precision); and sex, by observation of the presence of blotches in the belly and ventral parts of the thighs in males (Pinto, Wiederhecker \& Colli 2005). Individuals smaller than the smallest male with dimorphism were assigned as juveniles. Next, we marked each individual with a unique combination of clipped toes and released them a few meters from capture spot. Handling and marking procedures strictly followed animal handling regulations from the Brazilian federal council of biology (Conselho Federal de Biologia 2012) 
Costs to body condition

We accessed differences on body condition (as a surrogate of energetic cost of tail autotomy) using the "scaled mass index" (SMI) of Peig and Green (Peig \& Green 2009), computed as:

$$
\mathrm{SMI}: \widehat{M}_{\imath}=M_{i}\left(\frac{L_{0}}{L_{i}}\right)^{b_{S M A}}
$$

where $M_{i}$ and $L_{i}$ are the body mass and the SVL of individual $i$, respectively; $L_{0}$ is the mean SVL in the study population; and $b_{S M A}$ is a scaling factor. We computed $b_{S M A}$ from a standardized major axis (SMA) regression (Warton et al. 2006) of $\ln (M+1)$ on $\ln (L)$, using the package lmodel2 (Legendre 2014) in R environment ( $\mathrm{R}$ Core Team 2015). Unlike most conventional methods of estimating body condition, the SMI can successfully account for the varying relationship between $M$ and $L$ during ontogeny (Peig \& Green 2010) and is a good predictor of variations in fat and protein reserves in diverse vertebrate groups (Peig \& Green 2009). Next, we built a generalized linear mixed model (GLMM), implemented in the package lme4 (Bates et al. 2014), in which SMI was the response variable, tail state (autotomized vs. intact) was the fixed-effect, and year and individual (identity) were random effects to account for recaptures. We also used GLMMs to test for the significance of the relationship between the SMI (as response variable) with the proportion of the regenerated tail length (RTL. SVL ${ }^{-1}$ ). Later, we investigated the effects of tail state and RTL. $\mathrm{SVL}^{-1}$ between adults of each sex and juveniles. As SMI varied with SVL $\left(\chi^{2}{ }_{[1]}=234.55, P<\right.$ 0.001), we included it as a covariate in the tests. To assess the adequacy of the models we compared simpler models (including the random effects) with models with covariates to be tested via the Pearson $\chi^{2}$ statistic (Crawley 2013). 
Costs to body growth

To assess the potential costs of tail loss and regeneration to the body growth, we calculated the body growth rate as the difference in the SVL between two consecutive captures divided by the period between these captures in months. Next, we tested separately with GLMMs with year and individual (identity) as random effects, the fixed-effects of tail state (autotomized vs. intact) and RTL. SVL ${ }^{-1}$ on body growth rate, with SVL as a covariate $\left(\chi_{[1]}^{2}=25.86, P<0.001\right)$. We did not consider sex differences because of the small sample size in females and juveniles. We assessed the adequacy of the models as above.

Costs to survival and recapture probabilities

To determine the effects of tail loss on the survival and recapture rates and the relationship between frequency of autotomy and habitat openness, we used monthly individual capture histories and performed analyses in program MARK 8.0, implemented in the package RMark (Laake 2013). We created multi-state models, in which the tail state (autotomized vs. intact), the habitat openness (five stands corresponding to each burn regime plot), their interaction (tail state: regime) or a constant (.) could explain the apparent survival $(S)$ and the recapture probability $(p)$ rates. We also allowed the multi-state model to estimate the autotomy probability (psi) (Cooch \& White 2015). To obtain the transition from tail state (intact to autotomized) we fixed to zero the transition probability from tail state autotomized to the intact and included models constraining this parameter with the habitat openness to test for the relationship between tail state and habitat. Afterward, we investigated the effects of tail loss between each sex and juveniles through their interaction (tail state: sex), the variables alone (sex or tail state) or a constant (.). We ranked all possible models based on the AICc and model-averaged the rate probabilities when $\Delta$ AIcc $\leq 2$ 
(Burnham \& Anderson 2002). We made goodness-of-fit tests to test the assumptions of the multistate model using the program U-CARE v. 2.3.2 and all were acceptable (Choquet et al. 2009a).

Tail state and regeneration

To assess the effects of habitat openness, seasonality (based on the monthly insolation variation), sex, and ontogeny (based on the SVL) upon the occurrence of tail autotomy, we used a GLMM with a binomial error distribution and a logit link function (Crawley 2013). Further, we assessed the effects of these same variables on the proportion of the regenerated tail length (RTL. SVL ${ }^{-1}$ ). Adequacy of the models were conducted in a similar way as the body condition and growth sections. We calculated the tail regeneration rate in a similar way of the body growth, but instead of SVL, we used the RTL. SVL ${ }^{-1}$. As the response of tail regeneration rate to the ontogeny (average SVL between two consecutive captures) was not linear, we tested the removal effect of SVL via Fisher statistic with a generalized additive model with a Gaussian error distribution, implemented in the package $m g c v$ in R (Wood 2004; Crawley 2013). We conducted all statistical analyses with R v. 3.1.3 (R Core Team 2015) and we used a significance level of 5\% when testing hypotheses.

\section{Results}

In four years, we captured 494 individuals, representing 672 captures and recaptures in the five populations monitored. On average, each lizard was captured 1.26 times and $8.91 \%$ of the individuals had autotomized tails. From 621 individuals sexed, 313 were addressed to juveniles, 90 to females and 218 to males. Overall, individuals with intact tails of Tropidurus itambere present tails $21 \%$ longer than their SVL (Table 1), averaging $57.52 \pm 19.68 \mathrm{~mm}$ (range: $21-109 \mathrm{~mm}$ ), in 
Table 1 Averages [mean \pm SD (mininum-maximum)] of snout-vent length (SVL, in mm), body condition (scaled mass index), body growth (mm. month $\left.{ }^{-1}\right)$, tail length $(\mathrm{mm})$, regenerated tail length (RTL, in $\left.\mathrm{mm}\right)$, proportion of tail length in relation to the snout-vent length (Tail length. SVL ${ }^{-1}$ ), and the proportion of the regenerated tail length (RTL. SVL ${ }^{-1}$ ) of Tropidurus itambere at Reserva Ecológica do IBGE, Brasília, Distrito Federal, Brazil.

\begin{tabular}{llll}
\hline & All & Tail intact & Tail autotomized \\
\hline Pooled individuals & $(\mathrm{n}=632)$ & $(\mathrm{n}=571)$ & $(\mathrm{n}=61)$ \\
SVL & $48.23 \pm 15.51(21-85)$ & $47.59 \pm 15.42(21-85)$ & $54.34 \pm 15.07(27-80)$ \\
Body condition $(\mathrm{n}=564 ; \mathrm{n}=511 ; \mathrm{n}=53)$ & $4.15 \pm 1.49(0-17.59)$ & $4.12 \pm 1.51(0-17.59)$ & $4.41 \pm 1.26(1.46-6.37)$ \\
Body growth $(\mathrm{n}=106 ; \mathrm{n}=88 ; \mathrm{n}=18)$ & $3.39 \pm 2.34(0-9)$ & $3.47 \pm 2.33(0-9)$ & $3.00 \pm 2.40(0-9)$ \\
Tail length & $56.29 \pm 20.16(7-109)$ & $57.52 \pm 19.68(21-109)$ & $44.74 \pm 21.07(7-81)$ \\
RTL & $1.31 \pm 5.92(0-56)$ & - & $13.56 \pm 14.14(0-56)$ \\
Tail length. $\mathrm{SVL}^{-1}$ & $1.17 \pm 0.20(0.24-2.09)$ & $1.21 \pm 0.13(0.58-2.09)$ & $0.80 \pm 0.29(0.24-1.30)$ \\
RTL. SVL $^{-1}$ & $0.02 \pm 0.10(0.00-0.75)$ & - & $0.23 \pm 0.22(0-0.75)$ \\
\hline Adult females & $(\mathrm{n}=89)$ & $(\mathrm{n}=81)$ & $(\mathrm{n}=8)$ \\
SVL & $62.52 \pm 8.62(40-79)$ & $62.05 \pm 8.88(40-79)$ & $67.25 \pm 2.12(64-70)$ \\
Body condition $(\mathrm{n}=85 ; \mathrm{n}=78 ; \mathrm{n}=7)$ & $4.65 \pm 0.85(2.35-7.01)$ & $4.59 \pm 0.86(2.35-7.01)$ & $5.26 \pm 0.48(4.34-5.74)$ \\
Body growth $(\mathrm{n}=22 ; \mathrm{n}=20 ; \mathrm{n}=2)$ & $1.78 \pm 1.73(0-4.5)$ & $1.94 \pm 1.72(0-4.5)$ & $0.12 \pm 0.18(0-0.25)$ \\
Tail length & $70.01 \pm 11.89(20-90)$ & $72.42 \pm 8.71(44-90)$ & $45.62 \pm 12.73(20-60)$ \\
RTL & $1.71 \pm 7.29(0-48)$ & - & $19.00 \pm 17.13(4-48)$ \\
Tail length. $\mathrm{SVL}$ & & \\
RTL. $\mathrm{SVL}^{-1}$ & $1.13 \pm 0.19(0.31-1.52)$ & $1.18 \pm 0.12(0.72-1.52)$ & $0.68 \pm 0.18(0.31-0.90)$ \\
\hline Adult males & $0.03 \pm 0.11(0-0.72)$ & - & $0.28 \pm 0.25(0.06-0.72)$ \\
SVL & $(\mathrm{n}=213)$ & $(\mathrm{n}=182)$ & $(\mathrm{n}=31)$ \\
Body condition $(\mathrm{n}=197 ; \mathrm{n}=169 ; \mathrm{n}=28)$ & $5.06 \pm 1.58(1.46-17.59)$ & $5.12 \pm 1.62(2.49-17.59)$ & $4.7 \pm 1.26(1.46-6.37)$
\end{tabular}




\begin{tabular}{|c|c|c|c|}
\hline Body growth $(\mathrm{n}=51 ; \mathrm{n}=39 ; \mathrm{n}=12)$ & $3.71 \pm 2.5(0-9)$ & $3.89 \pm 2.66(0-9)$ & $3.11 \pm 1.89(0-6)$ \\
\hline Tail length & $72.51 \pm 16.49(22-109)$ & $75.34 \pm 14.30(40-109)$ & $55.90 \pm 18.81(22-81)$ \\
\hline RTL & $2.22 \pm 7.72(0-56)$ & - & $15.26 \pm 14.67(0-56)$ \\
\hline Tail length. SVL ${ }^{-1}$ & $1.20 \pm 0.20(0.38-2.09)$ & $1.25 \pm 0.14(0.74-2.09)$ & $0.91 \pm 0.25(0.38-1.30)$ \\
\hline RTL. SVL ${ }^{-1}$ & $0.04 \pm 0.12(0-0.75)$ & - & $0.25 \pm 0.22(0-0.75)$ \\
\hline Juveniles & $(\mathrm{n}=231)$ & $(n=219)$ & $(\mathrm{n}=12)$ \\
\hline SVL & $32.08 \pm 3.97(21-39)$ & $32.09 \pm 4.01(21-39)$ & $32.00 \pm 3.30(27-38)$ \\
\hline Body condition $(n=206 ; n=196 ; n=10)$ & $3.17 \pm 1.11(0-9.3)$ & $3.18 \pm 1.13(0-9.3)$ & $3.04 \pm 0.79(1.83-4.3)$ \\
\hline Body growth $(\mathrm{n}=27 ; \mathrm{n}=24 ; \mathrm{n}=3)$ & $3.92 \pm 1.86(0-7)$ & $4.1 \pm 1.85(0-7)$ & $2.44 \pm 1.5(1-4)$ \\
\hline Tail length & $37.13 \pm 7.28(7-60)$ & $38.07 \pm 5.72(21-60)$ & $20.00 \pm 11.05(7-36)$ \\
\hline RTL & $0.14 \pm 1.28(0-17)$ & - & $2.75 \pm 5.12(0-17)$ \\
\hline Tail length. SVL ${ }^{-1}$ & $1.16 \pm 0.18(0.25-1.70)$ & $1.19 \pm 0.11(0.11-0.58)$ & $0.62 \pm 0.34(0.25-1.20)$ \\
\hline RTL. SVL ${ }^{-1}$ & $0.00 \pm 0.04(0-0.57)$ & - & $0.09 \pm 0.17(0-0.57)$ \\
\hline
\end{tabular}


contrast to autotomized tails that averaged $44.74 \pm 21.07 \mathrm{~mm}(7-81)$. The average regenerated tail length (RTL) corresponds to $23.6 \%$ of the average intact tail length (Table 1).

Costs to body condition, body growth, and survival and recapture probabilities

There was no significant difference in the body condition between tailed and tailless individuals $\left(\chi^{2}[1]=0.08, P=0.773\right)$, neither in the interaction between tail state and $\operatorname{sex}\left(\chi^{2}[2]=4.47, P=\right.$ 0.107). Similarly, the RTL. SVL ${ }^{-1}$ did not affect the body condition alone $\left(\chi_{[1]}^{2}=3.40, P=0.065\right)$ or among males, females, and juveniles $\left(\chi_{[2]}^{2}=2.10, P=0.349\right)($ Table 1$)$. Tail state $\left(\chi_{[1]}^{2}=0.12\right.$, $P=0.729)$ and RTL. SVL ${ }^{-1}\left(\chi^{2}[1]=0.22, P=0.641\right)$ did not affect body growth.

Overall, the tail autotomy affected positively the survival when we pooled the data (Table 2 and 3). However, tail autotomy affected differently each sex and juveniles (Table 2). Males that lost tails had a subtraction of $10 \%$ on survival rate, and more than double recapture probability relative to those with intact tails (Table 3). Contrarily, females and juveniles that lost tails had higher survival rate, and lower recapture probabilities relative to those with intact tails (Table 3). The best models did not include habitat openness affecting the survival neither the probability of losing the tail (Tables 2 and 3).

Tail state and regeneration

The probability of losing the tail (change tail state) was not affected by habitat openness (i.e., no differences between plots: $\chi^{2}{ }_{[4]}<0.001, P=1.000$ ) (Fig. 2). Seasonality (insolation: $\chi^{2}{ }_{[1]}<0.001$, $P=0.991)$ and sex $\left(\chi^{2}[1]=0.016, P=0.901\right)$ did not affect probability of autotomy either, despite 
Table 2 Best MARK multi-state models $(\triangle \mathrm{AICc} \leq 2)$ with factors in parentheses, with respective number of parameters (npar), Akaike information criteria corrected for small sample sizes (AICc), difference between AICc and the best model's AICc ( $\triangle \mathrm{AICc})$, weight and deviance). Survival $(S)$, recapture $(p)$ and transition to state $(P s i)$ were constrained to vary with tail state, regime, sex, their possible interactions (tail state: regime and tail state: sex), or constantly (.).

\begin{tabular}{|c|c|c|c|c|c|}
\hline Model & npar & AICc & $\triangle \mathrm{AICc}$ & weight & Deviance \\
\hline \multicolumn{6}{|l|}{ tail state: regime } \\
\hline$S($ tail state) $p$ (regime) $P s i()$. & 8 & 1150.288 & 0.000 & 0.391 & 788.044 \\
\hline$S() p.($ regime $) P s i()$. & 7 & 1150.932 & 0.644 & 0.284 & 790.742 \\
\hline$S() p.($ tail state + regime $) P s i()$. & 8 & 1151.922 & 1.634 & 0.173 & 789.679 \\
\hline$S($ tail state $) p($ tail state + regime $) P s i()$. & 9 & 1152.173 & 1.885 & 0.152 & 787.869 \\
\hline \multicolumn{6}{|l|}{ tail state: sex } \\
\hline$S($ tail state: sex $) p($ tail state: $\operatorname{sex}) P s i($ sex $)$ & 17 & 1088.539 & 0.000 & 0.548 & 683.532 \\
\hline$S($ tail state: sex $) p($ tail state: sex $) P s i()$. & 15 & 1088.927 & 0.388 & 0.452 & 688.151 \\
\hline
\end{tabular}


Table 3 Model-averaged $(\triangle \mathrm{AICc} \leq 2)$ survival $(S)$, recapture $(p)$ and transition to state $(P s i)$ probabilities (estimate $\pm \mathrm{SE}$ ) among juveniles, females and males of Tropidurus itambere in regimes of different severity of fire at Reserva Ecológica do IBGE, Brasília, Distrito Federal, Brazil. C: control, EB: early biennial, LB: late biennial, MB: middle biennial, Q: quadrennial.

\begin{tabular}{llll}
\hline Group & $\boldsymbol{S}$ & $\boldsymbol{p}$ & $\boldsymbol{P s i}$ \\
\hline tail state: regime & & & \\
Intact tails in C & $0.75 \pm 0.02$ & $0.03 \pm 0.02$ & $0.02 \pm 0.01$ \\
Intact tails in Q & $0.75 \pm 0.02$ & $0.06 \pm 0.02$ & $0.02 \pm 0.01$ \\
Intact tails in EB & $0.75 \pm 0.02$ & $0.08 \pm 0.02$ & $0.02 \pm 0.01$ \\
Intact tails in MB & $0.75 \pm 0.02$ & $0.11 \pm 0.02$ & $0.02 \pm 0.01$ \\
Intact tails in LB & $0.75 \pm 0.02$ & $0.11 \pm 0.03$ & $0.02 \pm 0.01$ \\
Autotomized tails in C & $0.79 \pm 0.04$ & $0.03 \pm 0.02$ & 1 \\
Autotomized tails in Q & $0.79 \pm 0.04$ & $0.07 \pm 0.02$ & 1 \\
Autotomized tails in EB & $0.79 \pm 0.04$ & $0.09 \pm 0.03$ & 1 \\
Autotomized tails in MB & $0.79 \pm 0.04$ & $0.12 \pm 0.03$ & 1 \\
Autotomized tails in LB & $0.79 \pm 0.04$ & $0.12 \pm 0.04$ & 1 \\
\hline tail state: sex & & & \\
Juveniles with intact tails & $0.33 \pm 0.07$ & $0.26 \pm 0.09$ & $0.07 \pm 0.07$ \\
Females with intact tails & $0.88 \pm 0.03$ & $0.07 \pm 0.02$ & $0.02 \pm 0.01$ \\
Males with intact tails & $0.76 \pm 0.03$ & $0.12 \pm 0.02$ & $0.02 \pm 0.01$ \\
Juveniles with autotomized & $0.79 \pm 0.07$ & $0.09 \pm 0.05$ & 1 \\
tails & & & \\
Females with autotomized & $0.95 \pm 0.05$ & $0.01 \pm 0.01$ & 1 \\
tails & & & \\
Males with autotomized tails & $0.66 \pm 0.08$ & $0.28 \pm 0.09$ & 1 \\
\hline
\end{tabular}


Tail intact

Autotomized
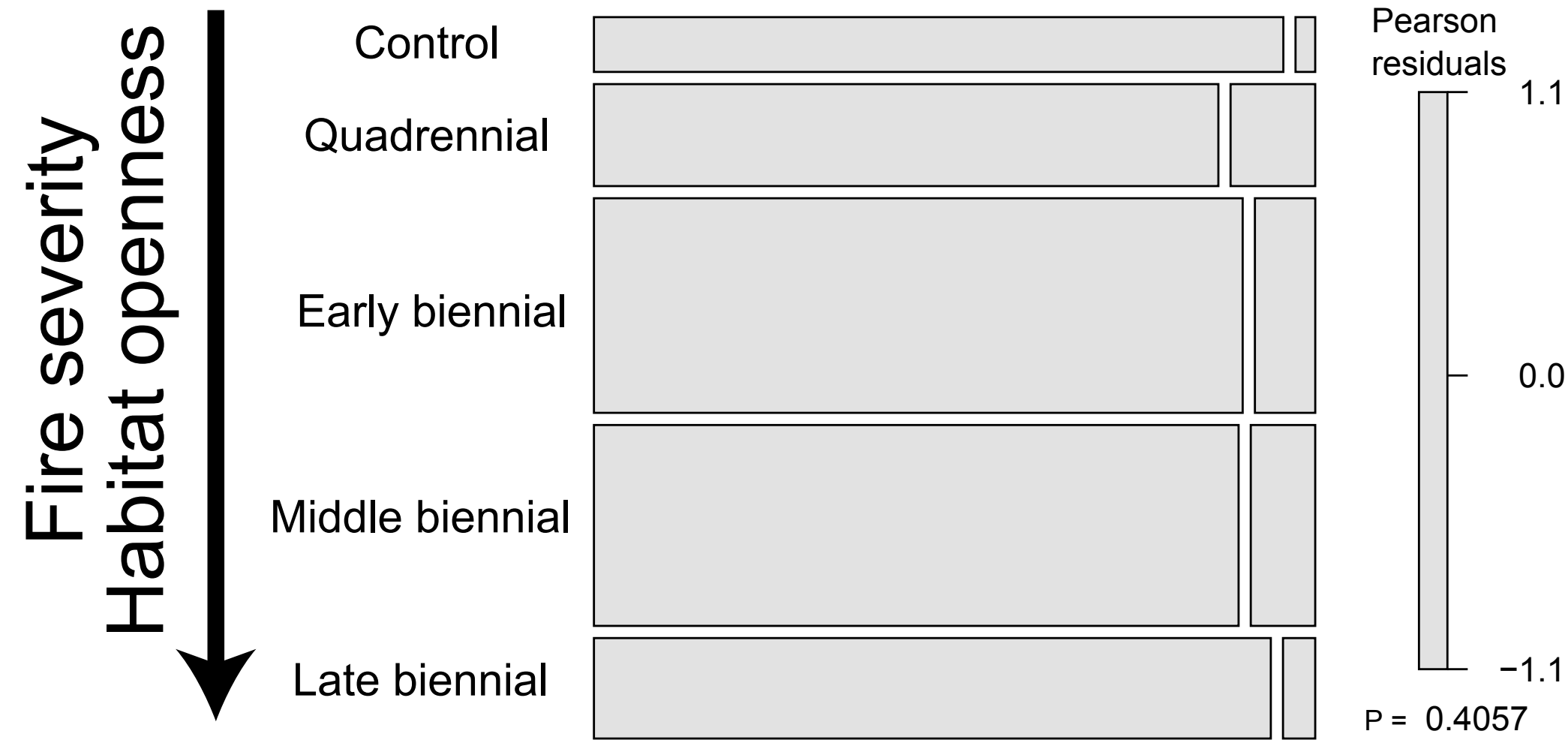

Fig. 2 Extended mosaic plot with residual-based shading depicting the proportion of individuals of the lizard Tropidurus itambere with autotomized or intact tails, in five experimental plots submitted to different burn regimes at Reserva Ecológica do IBGE, Brasília, Distrito Federal, Brazil. The width of each cell is proportional to the number of captured lizards. 
males having a slightly higher frequency of autotomy than females (14\% vs. 10\%). Conversely, ontogeny (SVL: $\left.\chi^{2}[1]=4.92, P=0.026\right)$ affected positively the probability of autotomy, with longer individuals (assumed to be older) having higher frequencies of autotomy (Fig. 3). Similarly, only the ontogeny affected RTL. SVL ${ }^{-1}\left(\mathrm{SVL}: \chi^{2}{ }_{[1]}=18.42, P<0.001\right.$; insolation: $\chi^{2}{ }_{[1]}=2.35, P=$ 0.125; plots: $\chi^{2}{ }_{[4]}=2.79, P=0.594$; and sex: $\left.\chi^{2}{ }_{[1]}<0.001, P=0.997\right)$ with a positive relationship (Fig. 4). In addition, ontogeny had a non-linear significant effect upon the tail regeneration rate $\left(F_{[2.71]}=0 ; P=0.02, \mathrm{r}^{2}=0.36\right)$. The response was modular, and the higher regeneration rates were concentrated between 50 and $60 \mathrm{~mm}$ of length (Fig. 5). The average tail regeneration rate was 13.88 $\pm 11.32 \mathrm{~mm}$. month ${ }^{-1}\left(\mathrm{n}=18\right.$; range: $1-33 \mathrm{~mm}$. month $\left.^{-1}\right)$.

\section{Discussion}

Costs to body condition, body growth, and survival and recapture probabilities

Individuals of Tropidurus itambere seem to have low (potentially irrelevant) costs regarding to energy loss, because we did not detect negative effects of autotomy in body condition, neither in body growth. Our results agree with other studies that investigated these costs, especially for body condition (or mass), since body condition was never negatively affected by the autotomy (Vitt \& Cooper 1986; Martin \& Salvador 1993b; Salvador \& López 1995; Naya et al. 2007; Cooper, Wilson \& Smith 2009; Pleguezuelos, Feriche \& Santos 2013). Authors explained the increases in body mass after autotomy by compensations with higher food intakes (Vitt \& Cooper 1986; Martin \& Salvador 1993b; Salvador \& López 1995). Another study with T. itambere, in the southeast Brazil also found that autotomy did not affect the body growth of individuals (Van Sluys 1998). 


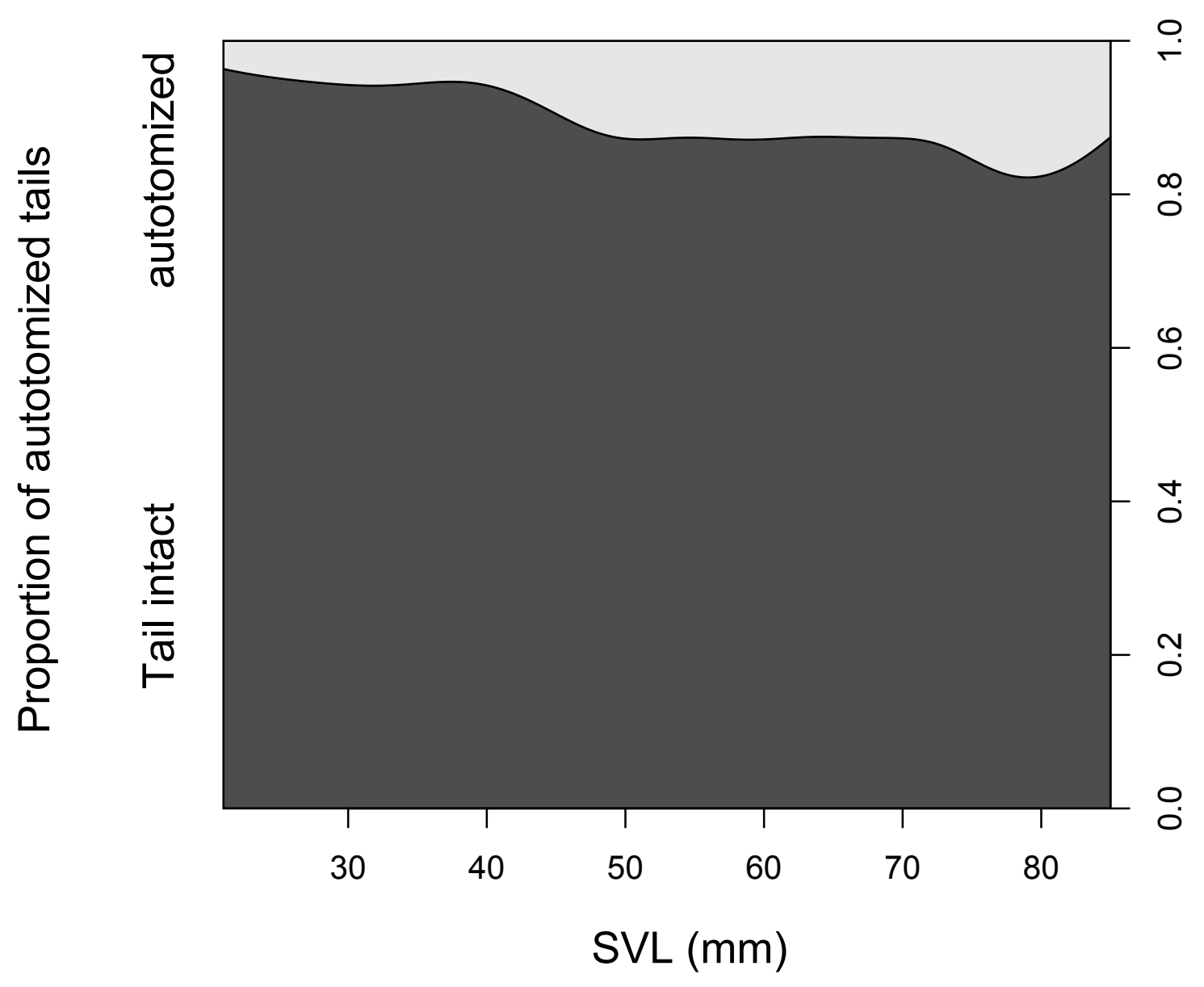

Fig. 3 Changes in the conditional distribution of tail state (intact vs. autotomized) according to snout-vent length (SVL) in T. itambere at Reserva Ecológica do IBGE, Brasília, Distrito Federal, Brazil. A smoothing approach via kernel density estimates was used to derive conditional probabilities. 


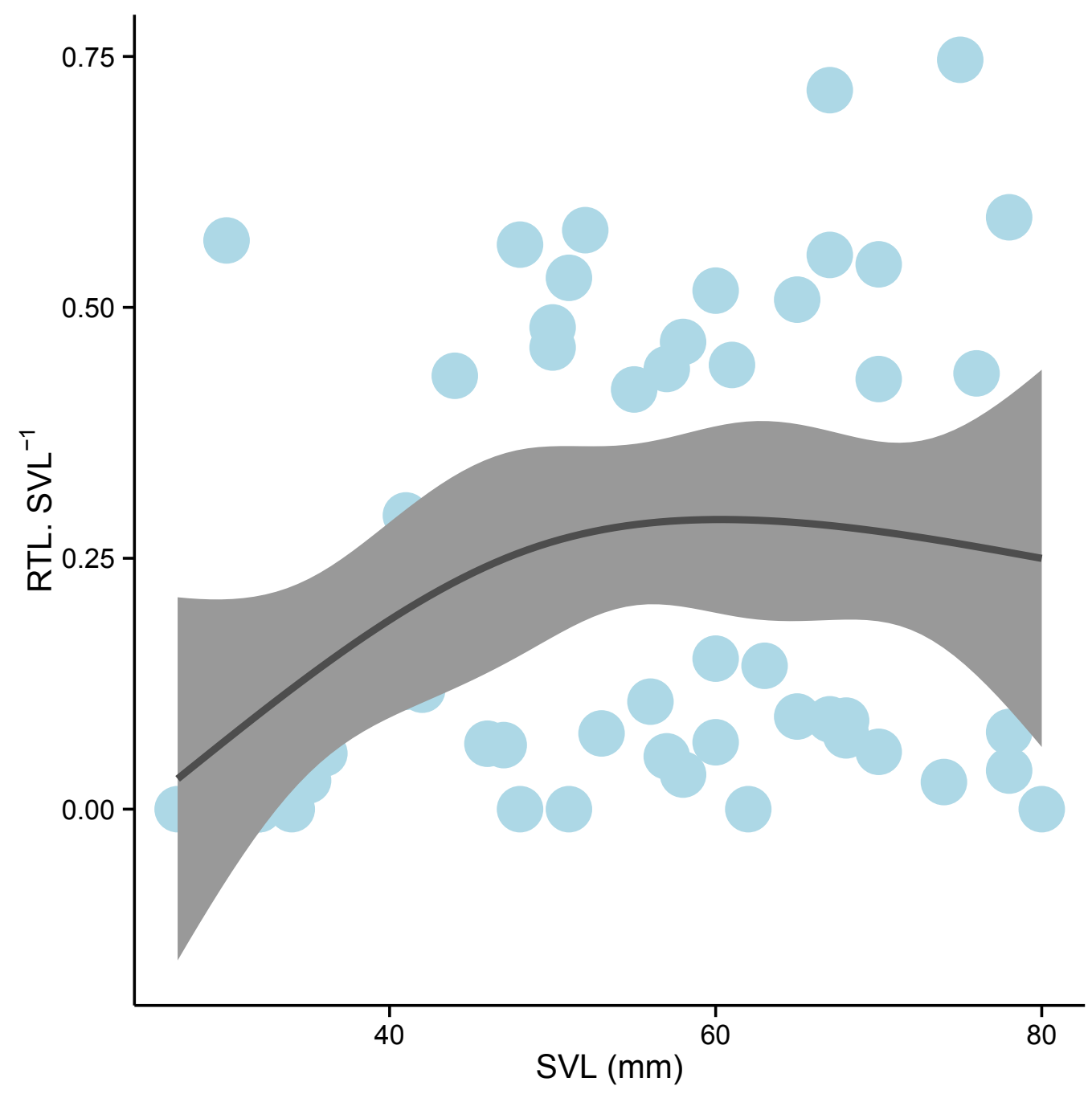

Fig. 4 Relationship between the proportions of regenerated tail length (RTL. SVL-1) and snout-vent length (SVL) in T. itambere at Reserva Ecológica do IBGE, Brasília, Distrito Federal, Brazil. The smoothing method used was linear. 


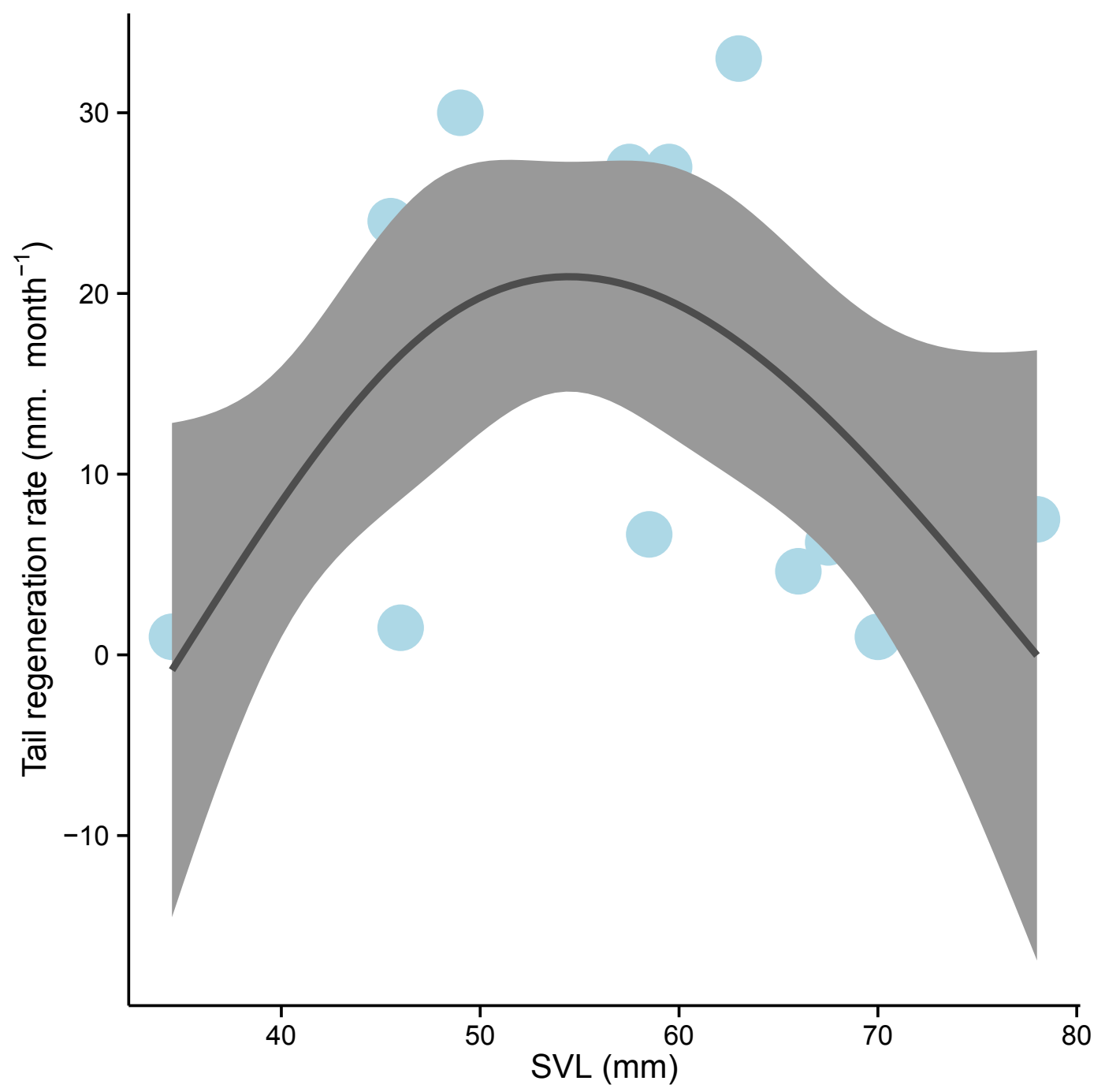

Fig. 5 Relationship between tail regeneration rate (mm. month-1) and snout-vent length (SVL) in T. itambere at Reserva Ecológica do IBGE, Brasília, Distrito Federal, Brazil. The smoothing method used was generalized additive model. 
As previously suggested by (Van Sluys 1998) results and in agreement with our data, $T$. itambere probably do not own high contents of lipid reserves in the tail, and individuals probably compensate for the tail loss and higher metabolism for tail regeneration increasing food intakes. Reduced locomotor performance after autotomy is very common in the close related lizard family Iguanidae (McElroy \& Bergmann 2013), and may affect the body condition and growth as well (Niewiarowski et al. 1997; Salvador \& Veiga 2005; Iraeta, Salvador \& Díaz 2012). However, $T$. itambere is an ambush foraging lizard that feeds upon ants and termites (Van Sluys 1993a; Faria \& Araujo 2004), which are considered relatively abundant and easily captured preys, especially in Cerrado (Colli, Constantino \& Costa 2006). Therefore, the generalist diet combined with small home range sizes, sedentary behavior, and tail breaks that occur in distal portions probably allow increase food intake of $T$. itambere without the necessity of individuals to change their activity patterns, which permit the individuals to maintain the body condition and continue to grow and regenerate the tail.

Following tail autotomy, lizards cannot perform it again in an immediately next predation attempt and may have increased mortality rates (Congdon, Vitt \& King 1974; Vitt, Congdon \& Dickson 1977; Daniels, Flaherty \& Simbotwe 1986; Vitt \& Cooper 1986; Medel et al. 1988; Downes \& Shine 2001; Langkilde, Alford \& Schwarkzopf 2005). After losing the tail, males of $T$. itambere were recaptured more and survived less. This may happen because of increased activity, and hence increased exposure to predators (Wilson 1992; Martin \& Salvador 1997). Autotomy can reduce social status in some species and lead individuals to lower quality areas (Fox \& Rostker 1982; Fox, Heger \& Delay 1990; Martin \& Salvador 1993b; Fox \& McCoy 2000), so males of $T$. itambere possibly need to expend more energy to maintain territory and social status after losing the tail. The opposite may happen for females and juveniles (Niewiarowski et al. 1997), which 
enhanced survival and were less recaptured after tail losses. However, females of T. itambere may reduce fecundity as consequence of reduced activity (Martin \& Salvador 1993b; Niewiarowski et al. 1997; Langkilde, Alford \& Schwarkzopf 2005). Although these results demonstrate how the sexual, spatial and temporal variations influence the effects of autotomy upon survival, there is a lack of studies regarding to the social costs due to tail loss and reproduction (Fox \& McCoy 2000).

\section{Adaptability}

The autotomy frequency of approximately $9 \%$ is one of the lowest already registered for the family Tropiduridae (Vitt 1983; Zani 1996; Galdino, Pereira \& Fontes 2006; Passos et al. 2013) and was lower in comparison to a previous study with the same species (23\%) (Van Sluys, Vrcibradic \& Rocha 2002). We argue that this low frequency is due to particular habitat features in our study area, where lizards are probably less exposed to predators. Van Sluys (Van Sluys, Vrcibradic \& Rocha 2002) studied T. itambere in pastures with rocky outcrops, whereas our study area lacks rocky outcrops and contains a more preserved and denser woody vegetation. Despite these differences, autotomy frequency is generally lower in ambush foraging species because of their high crypsis in relation to the substrate (Fleming, Valentine \& Bateman 2013).

Sexual differences in tail loss frequencies might be explained by intra-sexual aggressive encounters among males (Vitt 1981). Several species of Tropidurus perform territoriality and conspecific aggressive behaviors (Kohlsdorf, Ribeiro \& Navas 2006), and individuals of $T$. itambere have small home range sizes with little overlap, an evidence of territoriality (Van Sluys 1997). Nevertheless, we did not detect sexual differences in autotomy frequencies, what happens with more frequency among lizards, probably because both sexes share the same probability of 
predation (Bateman \& Fleming 2009). Besides, tail loss can lead to social costs and shed the tail of conspecifics may not be advantageous (Bateman \& Fleming 2009). Similarly, seasonality did not affect the autotomy frequencies, probably because the predation intensity does not vary seasonally. Ontogeny, however, affected the probability of an individual lose its tail (Fig. 3). This finding corroborates the idea that probability of suffering a predation attempt increases with age (time of life) (Vitt, Congdon \& Dickson 1977; Vitt \& Cooper 1986). Other possibilities are that adults are more conspicuous to predators because of their size (Vitt, Congdon \& Dickson 1977; Vitt \& Cooper 1986) or shed the tails more easily (Fox, Conder \& Smith 1998).

Predation attacks may be more frequent in more open habitats driven by fires (Shepard 2007a; Wilgers \& Horne 2007b). In our study, both survival rates and autotomy frequencies did not vary with the habitat openness (Table 2 and Fig. 2). Considering that in open habitats lizards are more exposed to predators, our work evidences that predation intensity or escape effectiveness in T. itambere do not vary with predation exposure within the studied gradient. Probably, the high camouflage of the species and other escape tactics (e.g. fleeing and hiding) decrease the potential frequency of tail loss (Fleming, Valentine \& Bateman 2013). Adding to our previous work with another Cerrado endemic lizard Micrablepharus atticolus (Sousa et al, submmited), this paper highlights the importance of the detection of the prey by the predator for the occurrence of a predation attempt (Lima \& Dill 1990; Schwarkzopf \& Shine 1992), which affects the caudal autotomy frequencies. Therefore, predation intensity is not only influenced by predator abundance, but also by their prey detection capacity, which also may be interpreted as predator efficiency. We argue that predation intensity, predation inefficiency, predator preferences, and prey abilities and availabilities are important drivers of the tail autotomy frequencies in natural lizard populations. 
The size of the regenerated portions increases along the ontogeny of $T$. itambere and stabilizes after certain size (Fig. 4). Accordingly, the tail regeneration rate is faster between a certain period of the adultness (Fig. 5). Tropidurus itambere is a short-lived species (may live until 2.5 years, at maximum), presents fast growing and early maturation, being sexually mature in the first year of life (Van Sluys 1993b; Van Sluys 1998; Van Sluys 2000). Our results show that tail regeneration is not a priority for the juveniles, because they need to allocate more energy to body growth and probably do not suffer high predation risk (Vitt, Congdon \& Dickson 1977). Thus, the slow regeneration in the early age demonstrates a tradeoff between growing body and regenerating tail, and when individuals achieve sexual maturity this tradeoff must reduce considerably. However, too old animals have also lower tail regeneration rates, maybe because they need to allocate more energy to reproduction (larger size often related to clutch size in females) or suffer lower risks of predation than smaller individuals (McCormick \& Polis 1982). Yet, larger males are often the dominant ones in the territory and to lose the tail is not a great cost to these animals (Martin \& Salvador 1993b), so investing in tail regeneration might not be energetically profitable for them. Therefore, tail presence seems to be more important during the early maturity than in any other period of life (youth or senescence). This pattern makes evolutive sense if individuals of $T$. itambere usually survive to only one reproductive season and if tail presence affects fecundity (because of social status, for example). Comparing to other species, $T$. itambere has in average similar tail regenerations rates than others that are considered fast tail regenerating species (Vitt 1981; Vitt \& Cooper 1986; Langkilde, Alford \& Schwarkzopf 2005; Tsasi et al. 2009; Iraeta, Salvador \& Díaz 2012).

In conclusion, the costs of tail loss to body condition, body growth, and survival in Tropidurus itambere are low, especially in females and juveniles. In addition, tail length is 
relatively smaller compared to other species; tail loss comprises only $24 \%$ of the average original tail length; frequency of tail autotomy was low in all populations; and tail regeneration rate was low in juveniles, revealing that other anti-predatory strategies as camouflage should be more important during early ages. These low costs may also have been resulted from behavioral changes after autotomy, as in food intake and activity. Reproductive and locomotory costs remain to be studied in the species and we highlight the lack of studies of tail autotomy in the Cerrado lizards.

\section{Acknowledgments}

We thank the staff of Reserva Ecológica do IBGE for being extremely supportive and all field assistants in this long-term study. We also thank Coordenação de Apoio à Formação de Pessoal de Nível Superior - CAPES, Conselho Nacional do Desenvolvimento Científico e Tecnológico - CNPq and Fundação de Apoio à Pesquisa do Distrito Federal - FAPDF for financial support.

\section{References}

Althoff DM, Thompson JN (1994) The effects of tail autotomy on survivorship and body growth of Uta stansburiana under conditions of high mortality. Oecologia 100:250-255

Anderson ML, Cavalieri CN, Rodríguez-Romero F, Fox SF (2012) The differential effect of tail autotomy on sprint performance between the sexes in the lizard Uta stansburiana. Journal of Herpetology 46:648-652. doi: 10.1670/11-166

Arnold EN (1984) Evolutionary aspects of tail shedding in lizards and their relatives. Journal of Natural History 18:127-169. doi: Doi 10.1080/00222938400770131

Arnold EN (1987) Caudal autotomy as a defense. In: Gans C, Huey RB (eds) Biology of the Reptilia. Volume 16. Ecology B. Defense And Life History. Alan R. Liss, Inc., New York, pp 235-273

Ballinger RE, Nietfeldt JW, Krupa JJ (1979) An experimental analysis of the role of the tail in attaining high running speed in Cnemidophorus sexlineatus (Reptilia: Squamata: Lacertilia). Herpetologica 35:114-116

Bateman PW, Fleming PA (2009) To cut a long tail short: a review of lizard caudal autotomy studies carried out over the last 20 years. Journal of Zoology 277:1-14. doi: Doi 10.1111/J.1469-7998.2008.00484.X 
Bateman PW, Fleming PA (2011) Frequency of tail loss reflects variation in predation levels, predator efficiency, and the behaviour of three populations of brown anoles. Biological Journal of the Linnean Society 103:648-656

Bates D, Maechler M, Bolker B, Walker S (2014) lme4: Linear mixed-effects models using Eigen and $\mathrm{S} 4, \mathrm{R}$ package version 1.1-7 edn

Boozalis TS, LaSalle LT, Davis JR (2012) Morphological and biochemical analyses of original and regenerated lizard tails reveal variation in protein and lipid composition. Comparative biochemistry and physiology. Part A, Molecular \& integrative physiology 161:77-82. doi: 10.1016/j.cbpa.2011.09.004

Burnham KP, Anderson DR (2002) Model Selection and Multi-Model Inference, 2nd edn. Springer-Verlag, New York

Chapple DG, McCoull CJ, Swain R (2002) Changes in reproductive investment following caudal autotomy in viviparous skinks (Niveoscincus metallicus): lipid depletion or energetic diversion? Journal of Herpetology 36:480-486

Chapple DG, Swain R (2002) Distribution of energy reserves in a viviparous skink: does tail autotomy involve the loss of lipid stores? Austral Ecology 27:565-572

Chapple DG, Swain R (2004) Inter-populational variation in the cost of autotomy in the metallic skink (Niveoscincus metallicus). Journal of Zoology 264:411-418. doi: $10.1017 / \mathrm{s} 0952836904005941$

Choquet R, Lebreton J-D, Gimenez O, Reboulet A-M, Pradel R (2009) U-CARE: Utilities for performing goodness of fit tests and manipulating capture-recapture data. Ecography 32:1071-1074. doi: 10.1111/j.1600-0587.2009.05968.x

Colli GR, Constantino R, Costa GC (2006) Lizards and termites revisited. Austral Ecology 31:417424. doi: 10.1111/j.1442-9993.2006.01598.x

Congdon JD, Vitt LJ, King WW (1974) Geckos: adaptive significance and energetics of tail autotomy. Science 28:1379-1380

Conselho Federal de Biologia (2012) Resolução n 301. In: CFBio (ed) 301, Brazil

Cooch EG, White GC (2015) Program MARK: a gentle introduction, URL: http://www.phidot.org/software/mark/docs/book/

Cooper WE, Jr. (1998) Reactive and anticipatory display to deflect predatory attack to an autotomous lizard tail. Canadian Journal of Zoology 76:1507-1510

Cooper WE, Jr. (2003) Shifted balance of risk and cost after autotomy affects use of cover, escape, activity, and foraging in the keeled earless lizard (Holbrookia propinqua). Behavioral Ecology and Sociobiology 54:179-187. doi: 10.1007/s00265-003-0619-y

Cooper WE, Jr. (2007) Compensatory changes in escape and refuge use following autotomy in the lizard Sceloporus virgatus. Canadian Journal of Zoology 85:99-107. doi: 10.1139/z06-200

Cooper WE, Jr., Prez-Mellado V, Vitt LJ (2004) Ease and effectiveness of costly autotomy vary with predation intensity among lizard populations. Journal of Zoology 262:243-255. doi: $10.1017 / \mathrm{s} 095283690300462 \mathrm{x}$

Cooper WE, Jr., Wilson DS (2010) Longer hiding time in refuge implies greater assessed risk after capture and autotomy in striped plateau lizards (Sceloporus virgatus). Herpetologica 66:425-431. doi: 10.1655/09-052.1

Cooper WE, Jr., Wilson DS, Smith GR (2009) Sex, reproductive status, and cost of tail autotomy via decreased running speed in lizards. Ethology 115:7-13. doi: 10.1111/j.14390310.2008.01575.x

Costa BM (2011) Queimadas e lagartos do Cerrado efeitos diretos e indiretos. Master Thesis, Universidade de Brasília, Brasília, DF 
Crawley MJ (2013) The R Book. John Wiley \& Sons Ltd., Chichester

Cromie GL, Chapple DG (2012) Impact of tail loss on the behaviour and locomotor performance of two sympatric Lampropholis skink species. PloS one 7:e34732. doi: 10.1371/journal.pone.0034732

Daniels CB, Flaherty SP, Simbotwe MP (1986) Tail size and effectiveness of autotomy in a lizard. Journal of Herpetology 20:93-96

Dial BE, Fitzpatrick L, C (1981) The energetic costs of tail autotomy to reproduction in the lizard Coleonyx brevis (Sauria: Gekkonidae). Oecologia 51:310-317

Domínguez-López ME, Ortega-león ÁM, Zamora-abrego GJ (2015) Tail autotomy effects on the escape behavior of the lizard Gonatodes albogularis (Squamata: Sphaerodactylidae), from Córdoba, Colombia. Revista Chilena de Historia Natural 88. doi: 10.1186/s40693-0140010-6

Downes S, Shine R (2001) Why does tail loss increase a lizard's later vulnerability to snake predators? Ecology 82:1293-1303

Faria RG, Araujo AFB (2004) Sintopy of two Tropidurus lizard species (Squamata: Tropiduridae) in a rocky Cerrado habitat in central Brazil. Brazilian Journal of Biology 64:775-786

Fleming PA, Valentine LE, Bateman PW (2013) Telling tails: selective pressures acting on investment in lizard tails. Physiological and Biochemical Zoology 86:645-658. doi: Doi $10.1086 / 673864$

Fox SF, Conder JM, Smith AE (1998) Sexual dimorphism in the ease of tail autotomy Uta stansburiana with and without previous tail loss. Copeia 2:376-382

Fox SF, Heger NA, Delay LS (1990) Social cost of tail loss in Uta stansburiana lizard tails as status-signalling badges. Animal Behavior 39:549-554

Fox SF, McCoy K (2000) The effects of tail loss on survival, growth, reproduction, and sex ratio of offspring in the lizard Uta stansburiana in the field. Oecologia 122:327-334

Fox SF, Rose E, Myers R (1981) Dominance and the acquisition of superior home ranges in the lizard Uta stansburiana. Ecology 62:888-893. doi: Doi 10.2307/1936985

Fox SF, Rostker MA (1982) Social cost of tail loss in Uta stansburiana. Science 218:692-693

Galdino CAB, Pereira EG, Fontes AF (2006) Defense behavior and tail loss in the endemic lizard Eurolophosaurus nanuzae (Squamata, Tropiduridae) from southeastern Brazil. Phyllomedusa 5:25-30

Hawlena D (2009) Colorful tails fade when lizards adopt less risky behaviors. Behavioral Ecology and Sociobiology 64:205-213. doi: 10.1007/s00265-009-0837-z

Hawlena D, Boochnik R, Abramsky Z, Bouskila A (2006) Blue tail and striped body: why do lizards change their infant costume when growing up? Behavioral Ecology 17:889-896. doi: 10.1093/beheco/arl023

Iraeta P, Salvador A, Díaz JA (2012) Effects of caudal autotomy on postnatal growth rates of hatchling Psammodromus algirus. Journal of Herpetology 46:342-345. doi: 10.1670/10321

Jaksic FM, Fuentes ER (1980) Correlates of tail losses in twelve species of Liolaemus lizards. Journal of Herpetology 14:137-141

Kohlsdorf T, Ribeiro JM, Navas CA (2006) Territory quality and male dominance in Tropidurus torquatus (Squamata, Tropiduridae). Phyllomedusa 5:109-118

Laake JL (2013) RMark: an R interface for analysis of capture-recapture data with MARK. AFSC Processed Rep. 2013-01. Alaska Fish. Sci. Cent., NOAA, Natl. Mar. Fish. Serv., 7600 Sand Point Way NE, Seattle WA 98115, p 25 
Langkilde T, Alford RA, Schwarkzopf L (2005) No behavioural compensation for fitness costs of autotomy in a lizard. Animal Ecology 30:713-718

Legendre P (2014) lmodel2: Model II Regression, R package version 1.7-2 edn

Lima SL, Dill LM (1990) Behavioral decisions made under the risk of predation: a review and prospectus. Canadian Journal of Zoology 68:619-640

Lin ZH, Qu YF, Ji X (2006) Energetic and locomotor costs of tail loss in the Chinese skink, Eumeces chinensis. Comparative Biochemistry and Physiology A 143:508-513. doi: 10.1016/j.cbpa.2006.01.018

Lu H-L, Gao J, Ma X, Lin Z, Ji X (2012) Tail loss affects fecundity but not offspring traits in the Chinese skink Eumeces chinensis. Current Zoology 58:228-235

Lu H-L, Ji X, Du W-G (2013) Tail loss reduces locomotor ability but not metabolic rate in a viviparous skink, Sphenomorphus indicus. Animal Biology 63:369-380. doi: 10.116.1/1.5707563-00002419

Martin J, Salvador A (1992) Tail loss consequences on habitat use by the Iberian rock lizard, Lacerta monticola. Oikos 65:328-333

Martin J, Salvador A (1993a) Tail loss and foraging tactics of the Iberian rock-lizard, Lacerta monticola. Oikos 66:318-324

Martin J, Salvador A (1993b) Tail loss reduces mating success in the Iberian rock-lizard, Lacerta monticola. Behavioral Ecology and Sociobiology 32:185-189

Martin J, Salvador A (1993c) Thermoregulatory behaviour of rock lizards in response to tail loss. Behaviour 124:123-136

Martin J, Salvador A (1997) Effects of tail loss on the time-budgets, movements, and spacing patterns of iberian rock lizards, Lacerta monticola. Herpetologica 53:117-125

McConnachie S, Whiting MJ (2003) Costs associated with tail autotomy in an ambush foraging lizard, Cordylus melanotus melanotus. African Zoology 38:57-65

McCormick S, Polis GA (1982) Arthropods that prey on vertebrates. Biological Review 57:29-58

McElroy EJ, Bergmann PJ (2013) Tail autotomy, tail size, and locomotor performance in lizards. Physiological and biochemical zoology : PBZ 86:669-679. doi: 10.1086/673890

McMillan DM, Irschick DJ (2010) Experimental test of predation and competition pressures on the green anole (Anolis carolinensis) in varying structural habitats. Journal of Herpetology 44:272-278

Medel RG, Jiménez JE, Fox SF, Jaksic FM (1988) Experimental evidence that high population frequencies of lizard tail autotomy indicate inefficient predation. Oikos 53:321-324

Miranda HS (2010) Efeitos do Regime do Fogo sobre a Estrutura de Comunidades de Cerrado: Resultados do Projeto Fogo. Ministério do Meio Ambiente; Instituto Brasileiro do Meio Ambiente e dos Recursos Naturais Renováveis; Centro Nacional de Prevenção e Combate aos Incêndios Florestais., Brasília

Miranda HS et al. (2011) Projeto Fogo. In: Ribeiro ML (ed) Reserva Ecológica do IBGE: Biodiversidade Terrestre, vol. 1. IBGE, Rio de Janeiro, pp 163-177

Naya DE, Veloso C, Munoz JL, Bozinovic F (2007) Some vaguely explored (but not trivial) costs of tail autotomy in lizards. Comparative Biochemistry and Physiology A 146:189-193. doi: 10.1016/j.cbpa.2006.10.014

Niewiarowski PH, Congdon JD, Dunham AE, Vitt LJ, Tinkle DW (1997) Tales of lizard tails effects of tail autotomy on subsequent survival and growth of free-ranging hatchling. Canadian Journal of Zoology 75:542-548 
Oliveira-Filho AT, Ratter JA (2002) Vegetation physiognomies and woody flora of the Cerrado biome. In: Oliveira PS, Marquis RJ (eds) The Cerrados of Brazil: Ecology and Natural History of a Neotropical Savanna. Columbia University Press, New York, pp 91-120

Oliveira PS, Marquis RJ (2002) The Cerrados of Brazil. Ecology and Natural History of a Neotropical Savanna. Columbia University Press, New York

Pafilis P, Foufopoulos J, Poulakakis N, Lymberakis P, Valakos ED (2009) Tail shedding in island lizards [Lacertidae, Reptilia]: decline of antipredator defenses in relaxed predation environments. Evolution; international journal of organic evolution 63:1262-1278. doi: 10.1111/j.1558-5646.2009.00635.x

Pantoja DL (2007) Efeitos do fogo sobre a taxocenose de lagartos em áreas de cerrado sensu stricto no Brasil Central. Master, Universidade de Brasília, Brasília, DF

Passos DC, Galdino CAB, Bezerra CH, Zanchi D (2013) Indirect evidence of predation and intraspecific agression in three sympatric lizard species from a semi-arid area in northeastern Brazil. Zoologia (Curitiba) 30:467-469. doi: 10.1590/s 198446702013000400016

Peig J, Green AJ (2009) New perspectives for estimating body condition from mass/length data: the scaled mass index as an alternative method. Oikos 118:1883-1891. doi: 10.1111/j.16000706.2009.17643.x

Peig J, Green AJ (2010) The paradigm of body condition: a critical reappraisal of current methods based on mass and length. Functional Ecology 24:1323-1332

Pianka ER, Huey RB (1978) Comparative ecology, resource utilization and niche segregation among gekkonid lizards in the southern Kalahari. Copeia 1978:691-701

Pianka ER, Pianka HD (1976) Comparative ecolgy of twelve species of noctural lizards in the western Australian desert. Copeia 1976:125-142

Pinto ACS, Wiederhecker HC, Colli GR (2005) Sexual dimorphism in the Neotropical lizard Tropidurus torquatus (Squamata, Tropiduridae). Amphibia-Reptilia 26:127-137

Pivello VR, Oliveras I, Miranda HS, Haridasan M, Sato MN, Meirelles ST (2010) Effect of fires on soil nutrient availability in an open savanna in Central Brazil. Plant Soil 337:111-123

Pleguezuelos JM, Feriche M, Santos X (2013) Tail-breakage effects on snake-body condition. Zoologischer Anzeiger 252:243-245. doi: 10.1016/j.jcz.2012.06.004

R Core Team (2015) R: a language and environment for statistical computing. R Foundation for Statistical Computing, Vienna, Austria

Ribeiro ML (ed) (2011) Reserva Ecológica do IBGE: Biodiversidade Terrestre. IBGE, Rio de Janeiro

Rodrigues MT (1987) Sistemática, ecologia e zoogeografia dos Tropidurus do grupo torquatus ao sul do rio Amazonas (Sauria, Iguanidae). Arquivos de Zoologia 31:105-230

Russell AP, Lynn SE, Powell GL, Cottle A (2015) The regenerated tail of juvenile leopard geckos (Gekkota: Eublepharidae: Eublepharis macularius) preferentially stores more fat than the original. Zoology. doi: 10.1016/j.zool.2014.12.003

Salvador A, López P (1995) Tail loss reduces home range size and access to females in male lizards, Psammodromus algirus. Behavioral Ecology 6:382-387

Salvador A, Veiga JP (2005) Activity, tail loss, growth and survivorship of male Psammodromus algirus. Amphibia-Reptilia 26:583-585

Schall JJ, Pianka ER (1980) Evolution of escape behavior diversity. Am Nat 115:551-566. doi: Doi $10.1086 / 283579$

Schoener TW (1979) Inferring the properties of predation and other injury-producing agents from injury frequencies. Ecology 60:1110-1115 
Schoener TW, Schoener A (1980) Ecological and demographic correlates of injury rates in some bahamian Anolis lizards. Copeia 1980:839-850

Schwarkzopf L, Shine R (1992) Costs of reproduction in lizards escape tactics and susceptibility to predation. Behavioral Ecology and Sociobiology 31:17-25

Shepard DB (2007) Habitat but not body shape affects predator attack frequency on lizard models in the brazilian Cerrado. Journal of Herpetology 63:193-202

Sousa HC et al. (submitted) Fire regimes and the demography of an endemic lizard in a savanna biodiversity hotspot. South American Journal of Herpetology

Sun YY, Yang J, Ji X (2009) Many-lined sun skinks (Mabuya multifasciata) do not compensate for the costs of tail loss by increasing feeding rate or digestive efficiency. Journal of experimental zoology. Part A, Ecological genetics and physiology 311:125-133. doi: 10.1002/jez.509

Tanner D, Perry J (2007) Road effects on abundance and fitness of Galapagos lava lizards (Microlophus albemarlensis). Journal of environmental management 85:270-278. doi: 10.1016/j.jenvman.2006.08.022

Tsasi G, Pafilis P, Simou C, Valakos ED (2009) Predation pressure, density-induced stress and tail regeneration: a casual-nexus situation or a bunch of independ factors? Amphibia-Reptilia $30: 471-482$

Van Sluys M (1993a) Food habits of the lizard Tropidurus itambere (Tropiduridae) in southeastern Brazil. Journal of Herpetology 27:347-351

Van Sluys M (1993b) The reproductive cycle of Tropidurus itambere (Sauria Tropiduridae) in southeastern Brazil. Journal of Herpetology 27:28-32

Van Sluys M (1997) Home range of the saxicolous lizard Tropidurus itambere (Tropiduridae) in southeastern Brazil. Copeia 1997:623-628

Van Sluys M (1998) Growth and body condition of the saxicolous lizard Tropidurus itambere in southeastern Brazil. Journal of Herpetology 32:359-365

Van Sluys M (2000) Population dynamics of the saxicolous lizard Tropidurus itambere (Tropiduridae) in a seasonal habitat of southeastern Brazil. Herpetologica 56:55-62

Van Sluys M, Vrcibradic D, Rocha CFD (2002) Tais loss in the syntopic lizards Tropidurus itambere (Tropiduridae) and Mabuya frenata (Scincidae) in southeastern Brazil. Studies on Neotropical Fauna and Environment 37:227-231

Vitt LJ (1981) Tail autotomy and regeneration in the tropical skink, Mabuya heathi. Journal of Herpetology 15:454-457

Vitt LJ (1983) Tail loss in lizards: the significance of foraging and predator escape modes. Herpetologica 39:151-162

Vitt LJ, Congdon JD, Dickson NA (1977) Adaptive strategies and energetics of tail autonomy in lizards. Ecology 58:326-337

Vitt LJ, Cooper WE, Jr. (1986) Tail loss, tail color, and predator escape in Eumeces (Lacertilia Scincidae): age-specific differences in costs and benefits. Canadian Journal of Zoology 64:583-592

Warton DI, Wright IJ, Falster DS, Westoby M (2006) Bivariate line-fitting methods for allometry. Biol Rev 81:259-291. doi: Doi 10.1017/S1464793106007007

Webb JK (2006) Effects of tail autotomy on survival, growth and territory occupation in freeranging juvenile geckos (Oedura lesueurii). Austral Ecology 31:432-440. doi: 10.1111/j.1442-9993.2006.01631.x

Wilgers DJ, Horne EA (2007) Spatial variation in predation attempts on artificial snakes in a firedisturbed tallgrass prairie. The Southwestern Naturalist 52:263-270 
Wilson BS (1992) Tail injuries increase the risk of mortality in free-living lizards (Uta stansburiana). Oecologia 92:145-152

Wilson RS, Booth DT (1998) Effect of tail loss on reproductive output and its ecological significance in the skink Eulamprus quoyii. Journal of Herpetology 32:128-131

Wood SN (2004) Stable and efficient multiple smoothing parameter estimation for generalized additive models. Journal of the American Statistical Association 99:673-686

Zani PA (1996) Patterns of caudal-autotomy evolution in lizards. Journal of Zoology 240:201-220 


\section{Conclusões Gerais}

A demografia de Micrablepharus atticolus e de Tropidurus itambere mostram claramente que mesmo animais adaptados a situações microclimaticamente extremas não possuem viabilidade populacional de longo prazo em condições adversas. Queimadas frequentes e intensas geram microclimas desfavoráveis para a sobrevivência e recrutamento destas espécies, pela provável redução do alimento e umidade para os indivíduos e desenvolvimento dos embriões. A supressão do fogo também é prejudicial às duas espécies, já que são heliófilas e mais abundantes em hábitats mais abertos, provavelmente devido a oportunidades termorregulatórias. As duas espécies apresentam reprodução sazonal e a insolação e temperatura foram as variáveis climáticas que melhor explicaram sua estrutura etária e parâmetros demográficos. Tais variáveis climáticas influenciam na disponibilidade alimentar, atividade, termorregulação, crescimento e desenvolvimento dos indivíduos, trazendo consequências para a sobrevivência.

Em Micrablepharus atticolus a autotomia caudal não está correlacionada com a eficiência de predação, mas sim com a intensidade de predação. No regime de queima intermediário de severidade e, consequentemente, de abertura do habitat, há menor frequência de caudas partidas e maior sobrevivência. Contudo, para Tropidurus itambere a frequência de autotomia caudal foi tão baixa que não houve diferenças ao longo do gradiente de abertura de habitat, assim como nas taxas de sobrevivência. Contudo, machos sofreram maior mortalidade após a perda das caudas, o que sugere que estes indivíduos não mudam o comportamento, pois os custos em manter o território e consequentemente reprodutivos podem ser grandes. Dessa forma, se expõem mais a predadores e sofrem maior mortalidade em comparação com jovens e fêmeas que também perderam a cauda. 
Este trabalho inova nas predições das populações de animais frente a diferentes regimes de queima em uma savana Neotropical. Em 100 anos, as populações de Tropidurus itambere correm pouco riscos de extinção, principalmente se queimadas bienais forem prescritas no começo da estação seca, entre maio e agosto. O uso de modelos de projeção integrais é uma ferramenta poderosa para se analisar a viabilidade populacional de espécies e estimar o risco de extinções futuras.

Os resultados deste trabalho sugerem a necessidade da criação de um programa de manejo de fogo no Cerrado, tanto dentro quanto fora de áreas protegidas. Pequenas queimadas prescritas no começo da estação seca, entre maio e agosto, que resultam em queimadas de baixa intensidade devem beneficiar espécies de sucessão do fogo precoce e tardia, pois além de criarem condições adequadas para espécies de animais especialistas em hábitats abertos, evitam que queimadas em áreas extensas e de intensidade alta modifiquem os hábitats fechados, favoráveis a espécies de sucessão tardia. 